IZA DP No. 9107

Explaining the Unexplained:

Residual Wage Inequality, Manufacturing Decline, and Low-Skilled Immigration

Eric D. Gould

June 2015 


\title{
Explaining the Unexplained: Residual Wage Inequality, Manufacturing Decline, and Low-Skilled Immigration
}

\author{
Eric D. Gould \\ Hebrew University of Jerusalem, \\ IZA, CEPR and CReAM
}

Discussion Paper No. 9107

June 2015

IZA

P.O. Box 7240

53072 Bonn

Germany

Phone: +49-228-3894-0

Fax: +49-228-3894-180

E-mail: iza@iza.org

\begin{abstract}
Any opinions expressed here are those of the author(s) and not those of IZA. Research published in this series may include views on policy, but the institute itself takes no institutional policy positions. The IZA research network is committed to the IZA Guiding Principles of Research Integrity.

The Institute for the Study of Labor (IZA) in Bonn is a local and virtual international research center and a place of communication between science, politics and business. IZA is an independent nonprofit organization supported by Deutsche Post Foundation. The center is associated with the University of Bonn and offers a stimulating research environment through its international network, workshops and conferences, data service, project support, research visits and doctoral program. IZA engages in (i) original and internationally competitive research in all fields of labor economics, (ii) development of policy concepts, and (iii) dissemination of research results and concepts to the interested public.
\end{abstract}

IZA Discussion Papers often represent preliminary work and are circulated to encourage discussion. Citation of such a paper should account for its provisional character. A revised version may be available directly from the author. 


\section{ABSTRACT \\ Explaining the Unexplained: Residual Wage Inequality, Manufacturing Decline, and Low-Skilled Immigration*}

This paper investigates whether the increasing "residual wage inequality" trend is related to manufacturing decline and the influx of low-skilled immigrants. There is a vast literature arguing that technological change, international trade, and institutional factors have played a significant role in the inequality trend. However, most of the trend is unexplained by observable factors. This paper attempts to "explain" the growth in the unexplained variance of wages by exploiting variation across locations (states or cities) in the United States in the local level of "residual inequality." The evidence shows that a shrinking manufacturing sector increases inequality. In addition, an influx of low-skilled immigrants increases inequality, but this effect is concentrated in areas with a steeper manufacturing decline. Similar results are found for two alternative measures linked to increasing inequality: the increasing return to education and the decline in the employment rate of non-college men. The overall evidence suggests that the manufacturing and immigration trends have hollowed-out the overall demand for middle-skilled workers in all sectors, while increasing the supply of workers in lower skilled jobs. Both phenomena are producing downward pressure on the relative wages of workers at the low end of the income distribution.

JEL Classification: J31

Keywords: inequality, manufacturing, low-skilled immigration

Corresponding author:

Eric D. Gould

Department of Economics

The Hebrew University of Jerusalem

Mount Scopus

Jerusalem 91905

Israel

E-mail: eric.gould@huji.ac.il

\footnotetext{
For many helpful comments, I thank David Autor and seminar participants at the Washington University in St. Louis, Ohio State, Boston University, and the University of Maryland. David Dorn provided help with the data from Autor, Dorn, and Hanson (2013). Sheri Band provided diligent research assistance and financial support was received from The Maurice Falk Institute for Economic Research. The first draft of this paper was written while visiting the Department of Economics at Georgetown University.
} 


\section{Introduction}

This paper examines the steady growth in income inequality over the last several decades in many advanced countries. Despite the vast literature on the topic, concrete explanations for this phenomenon have proved elusive. The evidence points to an important role for technological change, international trade, and changes in institutions. However, most of the inequality trend is left unexplained by observable factors like trade-flows, industrial and occupational shifts, changes in the education and demographic composition of the workforce, and the returns to observable skills.

This paper attempts to "explain” the growth in the unexplained variance of log wages by exploiting variation across locations (states or cities) in the United States in the local level of "residual inequality." A similar strategy has been used extensively in the literature to test whether the growth in the college wage premium is due to technological change, international trade, immigration, and other factors. However, the college premium is responsible for only a small portion of the inequality trend. This is the first paper to use a similar strategy to shed light on the growth in the largest, previously unexplained, portion of the wage variance over time.

The focus of the analysis will be on the role of the steady decline in the manufacturing industry and the influx of low-skilled immigrants in recent decades. Both of these trends coincided with the dramatic increase in wage inequality. The existing literature has found that the decline of the manufacturing sector, and the accompanying growth of the service sector, explains little of the increase in inequality over time. Similarly, low-skilled immigration has not been linked to significant growth in wage variation.

However, existing work ignores the idea that a shrinking manufacturing sector not only shifts workers across sectors of differing means and variances in wages, but could also create a general equilibrium effect on the shape of the distribution of wages within all sectors. Specifically, a decline in the demand for manufacturing workers could translate into a decline in the demand for similar, middle-skilled workers across all sectors of the local labor market. The hollowing-out in the demand for middleskilled workers could also lead to a labor supply shift away from middle-skilled jobs into lower skilled jobs. In this manner, the wage distribution in sectors outside of manufacturing could be affected by the deindustrialization trend over the last several decades. Similarly, an influx of low-skilled immigrants could impact upon the wages 
of workers in sectors which employ immigrant workers, and also in sectors which employ native workers of similar skill levels.

In order to establish causality, the analysis controls for national trends and the unobserved fixed-effect for each locality using a panel data set of cities or states in the United States over time from 1970 to 2010. In addition, we use instrumental variables for the local share of workers who are immigrants or in the manufacturing sector. These instruments are based on the historical geographic patterns of immigrants and industrial sectors, combined with national industrial shifts and national flows of immigrants from different origin countries. These instruments are widely used in the literature, but have never been used to estimate the causal impact of immigrants or the manufacturing sector on residual inequality. In addition, we use a measure of the local exposure to Chinese import competition from Autor, Dorn, and Hanson (2013) to instrument for the shift in the local manufacturing sector after 1990.

There is a well-developed literature that documents, and attempts to explain, the increase in wage inequality over recent decades. There is some quarreling over when the trend began, but most of the evidence points to the early 1970's (Juhn, Murphy, and Pierce (1993)). ${ }^{1}$ However, the nature of the inequality trend has changed over time. Wage variation within groups (by age, education, occupation, etc.) increased since the 1970's, while wage variation between education groups (i.e. the return to education) increased since the 1980's. Furthermore, inequality increased initially due to both tails of the distribution spreading out, while increases after 1990 were concentrated in the upper tail of the distribution (Autor, Katz, and Kearney (2008)).

Several explanations for these patterns have been explored in extensive detail over the last few decades: skill-biased technological change (the computer and IT revolution), international trade, shifts in the occupational and industrial composition, the decline in unions, changes in the minimum wage, immigration from low-wage countries, etc. The debate over the size and role of each one is ongoing, but a general consensus has emerged that technological advances over the last several decades have increased the demand for skill - increasing the returns to skill and leading to a fanning-out of the wage distribution.

\footnotetext{
${ }^{1}$ See Lemieux (2006) and Autor, Katz, and Kearney (2008).
} 
The remaining factors are often found to play a significant role, at least during certain stretches, but appear unlikely to account for the sustained increase in inequality throughout the whole period along with the way it has changed over time. For instance, the decline in the real minimum wage during the 1980's may have contributed to the increase in inequality at the bottom of the wage distribution during this period, but is thought to be unrelated to the increase at the top of the distribution along with its acceleration since 1990. Shifts in the occupational and industrial structure, due to international trade and the expansion of the service sector, have been difficult to reconcile with the increasing variance of wages within sectors over time (Juhn, Murphy, and Pierce (1992)). Similarly, the decline in unions may have increased wage variation within historically unionized sectors, but again seems unable to explain why inequality is increasing within all sectors. The impact of low-skilled immigration is heavily debated, but even studies that find a significant negative effect on the wages of low-skilled natives do not suggest that immigration played a large role in the upward trend in inequality between education groups (the college premium). No study has looked at whether immigration affected the overall wage variance, including the variation within education groups.

Direct evidence for the case that technological change is significantly altering the wage structure comes from exploiting variation across states (or across industries, cities, or countries) in the education premium, and showing a positive relationship between investments in new technologies (computers, $R \& D$, etc.) and the skill premium. $^{2}$ In addition, skill-upgrading - the increasing proportion of skilled workers in a given sector or locality, is positively related to the skill premium. ${ }^{3}$ This finding is consistent with technologically-driven demand shifts in favor of high-skilled workers.

Recent papers have also linked technological investments to the replacement of workers performing tasks which are more routine in nature, and thus, highly susceptible to be automated and replaced by computers and advanced equipment. ${ }^{4}$ Autor and Dorn (2013) exploit variation across locations (commuting zones) in the US to show that areas which have an initially larger share of workers in routine-type occupations underwent a larger polarization of workers into high-skilled and low-

\footnotetext{
2 See Berman, Bound, and Griliches (1994), Berman, Bound, and Machin (1998), Autor, Katz, and Krueger (1998), Machin and Van Reenen (1998), and Lindley and Machin (2013).

3 See Murphy and Welch (1992), Katz and Murphy (1992), Berman, Bound, and Griliches (1994), Berman, Bound, and Machin (1998), and Autor, Katz, and Kearney (2008).

${ }^{4}$ See Autor, Levy, and Murnane (2002), Goos and Manning (2007), Autor, Katz, and Kearney (2008), Autor and Dorn (2013), Michaels, Natraj, and Van Reenen (2014).
} 
skilled occupations. Specifically, they find that new technologies replaced workers performing routine jobs, resulting in an increase in the wages and employment share of low-wage service occupations. ${ }^{5}$ Their findings demonstrate how technology adoption has hollowed out the demand for workers in occupations that are typically in the middle of the wage distribution, while increasing the employment share and wages in occupations at the tails of the distribution. These findings are consistent with the stabilization of inequality at the lower tail since the 1990's, and the concurrent acceleration in the upper tail. However, their analysis is concerned with how technology affects inequality through occupational shifts, and does not address the increase in inequality within all sectors over time - the increase in "residual inequality."6

Recent work has shown that increasing levels of trade with China have altered the structure of the U.S. labor market. Using variation across localities in their exposure to Chinese imports (i.e. based on the initial local share of goods produced that potentially compete with Chinese goods), Autor, Dorn, and Hanson (2013a) show that trade with China displaced workers from manufacturing jobs. Workers shifting to other sectors exerted downward pressure on wages in the service sector due to the shift in labor supply and to a decline in demand for services. ${ }^{7}$ In follow-up work, Autor, Dorn, and Hanson (2013b) find that exposure to Chinese imports adversely affected the unemployment and non-employment rates of less-educated workers, with much smaller effects on college-educated workers. Using longitudinal data, Autor, Dorn, Hanson, and Song (2013) show that low-wage manufacturing workers exposed to trade with China experienced larger wage losses than high-wage workers.

These findings suggest that trade with China may have implications for inequality between, and perhaps within, education groups. However, this link has not

\footnotetext{
5 The increased wages of service workers depends theoretically on the assumption that goods and services are weakly complementary. In other words, computerization leads to a decline in the costs, and prices, of goods - and this leads to an increase in the demand for services which serves to increase the wages of service workers. See Autor and Dorn (2013).

${ }^{6}$ However, Acemoglu and Autor (2012) show that inequality between occupations is becoming more important over time - they show that the explanatory power of occupations (and also tasks) is growing over time in a typical wage regression.

${ }^{7}$ However, they find that the decline in wages was similar in magnitude for educated and less-educated workers, thus implying an ambiguous effect on overall inequality or inequality between education groups. The authors also find that the wages of workers remaining in the manufacturing sector did not decline in response to increase exposure to Chinese imports. This, however, may be due to the positive selection (in terms of wages) of workers remaining in the manufacturing sector, or due to an endogenous response of firms to adopt new technologies in order to compete with Chinese imports (Bloom, Draca, and Van Reenen (2011)).
} 
yet been investigated directly. But, it is unlikely that trade with China is responsible for much of the inequality trend, which started in the 1970's and preceded the Chinese import phenomena which began in the early 1990's. For this reason, we examine the general equilibrium effect of manufacturing decline on inequality, rather than focusing on trade with China.

Examining the role of the manufacturing sector is also motivated by Moretti (2010) who shows that 1.6 jobs in the non-tradable sector are created for every job created in the manufacturing sector. This finding, along with the effects of trade with China on sectors outside of manufacturing (cited above), provides additional evidence in favor of the idea that the decline in manufacturing may generate important spillovers on the structure of wages and employment in all sectors.

As noted above, there is a developed literature on the issue of whether immigrants hurt the labor market outcomes of natives. The evidence is inconclusive (Friedberg and Hunt (1995)). Borjas, Freeman, and Katz (1997) use the 1980 and 1990 U.S. Census data to examine whether an influx of immigrants at the local level is associated with lower wages. In addition, they exploit variation in the immigrant concentration by skill levels, and their overall findings point to a negative effect of immigration on the wages of less-skilled natives. Borjas (2003) extends this analysis to examine the flows of immigrants within education-experience levels, and finds similar results.

Card (2005) reaches different conclusions by showing that there is no correlation between the gap in wages between high school graduates and dropouts at the city level and the fraction of high school dropouts in the city that are immigrants. Card (2009) extends this analysis by looking at how immigrants are affecting relative supplies of workers at different education levels by city, and finds little correlation with relative wage levels in the cross-section for the 2000 Census. ${ }^{8}$ The endogenous locational choices of immigrants are handled by using an instrumental variable based on earlier immigrant settlement patterns along with the national trends for each type of immigrant.

\footnotetext{
${ }^{8}$ Friedberg (2001) examines whether the massive wave of Russian immigration into Israel affected the wages of workers, while exploiting variation across sectors in the increase in labor supply due to the Russian immigrants. Friedberg uses the sector choice of Russian immigrants prior to their emigration from Russia as an instrument for the allocation of immigrants across sectors in Israel, and finds little evidence that the new immigrants lowered the wages of natives. Ottaviano and Peri (2012) reach similar conclusions.
} 
This paper follows the literature that exploits variation in the immigrant concentration across localities and over time, as well as employing a similar instrumental variable strategy. However, we make several contributions. First, we examine how immigration affects residual wage inequality, not just the wage gaps between skill levels. Second, we analyze a longer time horizon by using a panel of localities for every ten years between 1970 and 2010. Third, we also examine the effect of immigration on the employment rate of natives, since a decline in the employment rate can be considered a manifestation of the inequality trend (Juhn (1992)). Finally, we examine the role of immigration in conjunction with the decline in manufacturing. These two phenomena may interact with each other if the downward pressure on native wages due to an increased supply of low-skilled immigrants is weaker (stronger) in areas where the manufacturing sector is robust enough (too small) to prop up the demand for middle and lower skilled natives. Also, Lewis (2009) argues that an influx of immigrants leads manufacturing firms to invest less in labor-saving equipment and technology, thus mitigating the effect of immigration on the wages of less-skilled workers. It naturally follows that the mitigating effect of this mechanism should be related to the size of the manufacturing sector, and therefore, implies that the effect of immigration and manufacturing should be examined together.

Overall, our analysis uses established tools in order to examine a new question: Is residual inequality affected by manufacturing decline and an influx of immigrants? The analysis shows that the decline in manufacturing played a significant role in the upward trend in inequality. This finding is robust across many dimensions: different measures of inequality, different time periods, using OLS or IV, using states versus cities as the unit of analysis, the inclusion or exclusion of additional control variables, and controlling for location-specific time trends. In addition, the evidence shows that low-skilled immigration has played a significant role as well, although the size of the effect depends on the size the manufacturing sector. The concentration of low-skilled immigrants in the local labor force increased residual wage inequality while lowering the employment rates of non-college educated natives - but both effects are stronger when the manufacturing sector is shrinking. Similar results are obtained using the local "college premium" as the outcome variable of interest -demonstrating that all three dramatic trends in the structure of the labor market (the rising college premium, increasing residual inequality, and declining employment 
rates of non-college men) are linked to one another and are influenced by common factors. No previous paper has provided an empirical link between all three.

Overall, the results suggest that manufacturing decline and low-skilled immigration have hollowed-out the overall demand for middle-skilled workers in all sectors, while increasing the supply of workers in lower skilled jobs. As a result, inequality is rising and employment rates are falling over the last several decades, and the results indicate that most of this increase is due to the decline in the manufacturing employment share combined with the influx of low-skilled immigrants.

The paper is organized as follows. The next section presents the data and discusses the major labor market trends in inequality, employment rates, manufacturing, and immigration. Section III describes the empirical model and Section IV presents the results for the role of the manufacturing employment share on inequality. Section $\mathrm{V}$ examines the manufacturing decline in conjunction with the influx of low-skilled immigrants. Section VI examines two alternative measures of inequality: the employment rate of non-college men and the "college premium." Section VII presents an analysis at the commuting zone level using the "China Syndrome” instrument from Autor, Dorn, and Hanson (2013). Section VIII discuss the size of the estimated effects, and Section IX concludes.

\section{The Data}

The analysis uses US Census data from 1970, 1980, 1990, and 2000. In addition, the American Community Survey (ACS) for 2009, 2010, and 2011 are combined and referred to as the "2010" period. ${ }^{9}$ In order to abstract from issues related to race, gender, and ethnicity, our analysis focuses on white, native-born men between the ages of 25-55. To compute our measures for inequality, the sample is restricted to individuals who worked 30 hours per week, and are not self-employed, living in group quarters, or in the armed forces. For this sample, log wages are defined as total wage income divided by annual hours worked, which is computed

\footnotetext{
9 The data was downloaded from IPUMS (Ruggles et. al., 2010). The ACS is the largest representative survey that was conducted after 2000. Many existing studies examine inequality and other labor issues over time using the Census for years up to and including 2000, and the ACS for the post-2000 period. For example, see page 1050 of Acemoglu and Autor (2011) and page 1005 of Beaudry et. al. (2010).
} 
using the responses for "usual number of weeks worked" and "usual number of working hours per week”. Our main measure of wage inequality is the ratio between the $90^{\text {th }}$ and $10^{\text {th }}$ percentiles of the log wage distribution.

Figure 1 displays the familiar rise in the 90/10 ratio over time. According to the graph, the trend starts in the 1970's and continues to the present day, with an acceleration during the 1980's. These patterns are consistent with Autor, Katz, and Kearney (2008), as are the trends for inequality at the top versus the bottom of the distribution. ${ }^{10}$ Figure 2 shows that inequality at the bottom of the wage distribution, represented by the 50/10 wage ratio, increased during the 1970's and 1980's, and then leveled off. In contrast, inequality at the top half (the 90/50 ratio) was stable during the 1970's, and has grown steadily ever since. These patterns are similar to the trends in Acemoglu and Autor (2011), as displayed in Figure 3 for comparison purposes.

Figures 4 and 5 examine how much of the inequality levels and trends are due to changes over time in the observable characteristics of individuals (education, age, industry, and occupation) and the returns to these observable characteristics. The figures demonstrate the importance of each component by graphing the residual 90/10 ratio in stages after controlling for an additional set of individual characteristics. Controlling for age and education reduces the overall level of inequality considerably, as does controlling for industry and occupation. Finally, the lowest level of inequality in Figure 4 (the "UCM" graph) controls for all the variables mentioned above, but allows the coefficients to vary over time.

Figures 4 and 5 show that most of the trend in inequality is left unexplained by changes in the characteristics or returns to those characteristics over time. The overall 90/10 ratio increased from 1.12 to 1.50 from 1970 to 2010, while the residual measure went from 0.91 to 1.17 . That is, the overall measure increased by 0.38 log points, while the residual variance increased by $0.26 \log$ points. These results are consistent with Juhn, Murphy, and Pierce (1993), and show that despite the increasing returns to education (Katz and Murphy (1992)) and the "polarization” of workers into occupations at the lower and upper tails of the wage distribution (Autor, Katz, and Kearney (2008) and Autor and Dorn (2013)), most of the inequality trend is due to inequality increasing within groups defined by education, occupation, and industry.

\footnotetext{
${ }^{10}$ Our inequality trends using the Census and ACS data are very similar to the those using March CPS, which differs from the May/ORG CPS. See Autor, Katz, and Kearney (2008).
} 
Explaining the increase in inequality within groups (i.e. "residual inequality”) has proved allusive. To make progress on that front, our analysis will exploit geographic variation across the United States in the inequality trends. Figure 6 shows that residual inequality increased in all states from 1970-2000, but there is considerable variation in the rate of increase. Figure 7 displays similar, but larger changes between 1970 and 2010. Exploiting this variation will allow us to determine why inequality increased in certain states more than others, while shedding light on the factors underlying the aggregate trend as well.

The analysis will focus on the role of the manufacturing sector and the influx of low-skilled immigrants. As described in Baily and Bosworth (2014), the share of workers in the manufacturing sector has been declining steadily since the early 1970's. Figure 8 shows a 15 percentage point reduction in the employment share of this sector with our main sample. This contraction is largely due to international trade and technological improvements in productivity (see also Autor, Dorn, and Hanson (2013)). However, trade with China cannot be the main cause of deindustrialization, since trade levels with China did not become significant until the early 1990's.

The contraction of the manufacturing sector represents a significant decline in the job opportunities of middle-wage earners over the last several decades. Figure 9 ranks the main industrial classifications according to their mean wage in 1970, and manufacturing ranks firmly in the upper middle part of the wage spectrum. Perhaps not surprisingly, manufacturing wages are relatively high, conditional on observable characteristics of the individual. Appendix Figure 1 shows that the manufacturing sector has the second highest mean residual wage, after controlling for age and education.

Workers in manufacturing are well-paid, but typically have lower than average education levels (Appendix Figures 2 and 3). However, as described above, manufacturing jobs became increasingly scarce over time. Figure 10 shows that the manufacturing sector is a clear outlier - it is the only sector which underwent a large reduction in its employment share. ${ }^{11}$ The wage and employment patterns demonstrate how the decline in the manufacturing sector can be considered a significant reduction in the demand for well-paid, middle-class jobs. How this demand shift away from

\footnotetext{
11 The decline of the manufacturing sector was concentrated in the largest sectors as of 1970: Metal Industries, Transportation Equipment, Machinery and Computing, and Electronics. See Appendix Figures 5 and 6.
} 
middle-class work affected the variation in wages within all sectors is the question addressed in our analysis. A preliminary analysis in Figure 11 shows, however, that the decline in manufacturing at the state level is strongly related to the size of the state’s increase in inequality from 1980 to 2010.

As alternative measures of inequality, we will also examine the role of manufacturing decline on the falling employment rate of non-college educated males of prime working age, and the rise in the return to education. Figure 12 shows an approximate 13 percentage point decline in the employment rate of non-college males from 1970 to 2010, and Figure 13 displays the familiar fall in the "college premium" during the 1970's and the subsequent rise thereafter. ${ }^{12}$ Declining employment rates have been linked to increasing inequality by Juhn (1992), while the increasing return to education since 1980 is commonly thought to be driven by the same type of skillbiased technological change that is suspected to be driving the residual inequality trends. Since all three outcomes are thought to be related to each other, our analysis examines all three as a robustness check, and provides the first empirical link between them.

In addition to the decline in manufacturing, our analysis will examine the role of increased low-skilled immigration over recent decades on the rise in inequality. Figure 14 indicates that the share of the male population comprised of non-college graduate immigrants rose from about 5 percent in 1970 to 15 percent in 2010 . Appendix Figure 7 shows that this phenomenon occurred in almost every state throughout the US, but to varying degrees.

The influx of low-skilled immigrants represents an outward shift in the supply of workers considering lower-paying jobs, in addition to the potential supply shift of individuals who are increasingly not able to find employment in the manufacturing sector. We will examine how both of these factors affected a state's level of inequality, and how the two factors may have interacted with each other. For example, a large influx of immigrants may be more easily absorbed into a local labor market with minimal wage repercussions on native workers if the local economy has a thriving manufacturing sector.

\footnotetext{
${ }^{12}$ The college premium is estimated by regressing log wages on age, state, year, and dummy variables for the main education groups (high school dropouts, high school graduates, college dropouts, college graduates, and those with more than a college degree). The "college premium" is the coefficient on "college graduate", with high school graduates being the omitted category.
} 
The main empirical analysis uses measures aggregated to the state-year level, and summary statistics for the main variables of interest appear in Table 1 . Table 1 displays the same patterns displayed in the figures described above using individual level data. In addition, the table presents the means for some of the variables used to test alternative mechanisms, such as union density, the minimum wage, patenting levels, and the employment share of blue-collar workers.

\section{Empirical Strategy}

The empirical strategy to identify the causal effect of the manufacturing sector on inequality is to exploit variation across states and over time with the following equation:

$$
\text { Inequality }_{i t}=\alpha M F G_{i t}+\beta X_{i t}+\mu_{i}+\delta_{t}+\varepsilon_{i t}
$$

where Inequality $_{i t}$ is a measure for the wage variation in state $i$ in year $t, M F G_{i t}$ equals the percent of all men in our main sample who work in the manufacturing sector for at least 20 hours a week in state $i$ in year $t, X_{i t}$ is a vector of time-varying state-level characteristics (the education and age composition), $\mu_{i}$ is a fixed-effect unique to state $i$, and $\delta_{t}$ is an aggregate fixed-effect for each year $t$. Unobserved components of a state's level of inequality are captured by the error term, $\varepsilon_{i t}$.

The main identifying assumption in equation (1) is that the employment share of workers in the manufacturing sector in state $i$ and year $t\left(M F G_{i t}\right)$ is not correlated with unobserved determinants of the local level of inequality. Support for this assumption is provided by showing that the results are robust to the inclusion or exclusion of various observed determinants of local inequality, as well as the inclusion of state-specific linear time trends. Furthermore, an instrument for the local employment share in manufacturing over time is created with information on the initial industrial composition of workers across states and the aggregate trends of each industry. This strategy is based on the idea that a national decline in a certain industry will affect areas where this industry was heavily concentrated in the initial period, relative to the rest of the country. The national decline in any particular industry is 
considered to be exogenous to the local factors affecting a particular state's level of inequality over time. This instrument was developed in Bartik (1991) and Blanchard and Katz (1992), and has been used recently to instrument for the local level of manufacturing decline (Charles, Hurst, and Notowidigdo (2013)).

\section{The Impact of Manufacturing on Inequality}

Table 2 shows the main OLS results of equation (1) for various measures of inequality as the dependent variable. All of the regressions in the main text of the paper are weighted by the local population in 1990. Robust standard errors clustered at the state (or later at the metro area) level are reported in the tables.

The first column in Table 2 uses the unadjusted 90/10 ratio in log wages. The significant, negative coefficient indicates that a decline in the manufacturing sector increases inequality. Similar findings are displayed for the 90/10 ratio after adjusting in incremental stages for age and education (column (2)), returns to age and education over time (column (3)), and shifts in the occupation and industrial structure (column (4)). The latter finding is notable since this measure of residual inequality already controls for changes in the industrial and occupational composition of the local labor market with dummy variables for each person's sector of work. The finding that there is still a strong, negative effect shows that the decline in the manufacturing sector is creating a significant, general equilibrium effect on the variation of wages within all sectors. The last column of Table 2 shows similar results for the state-level Gini coefficient of household income - a different measure of inequality that was computed by the Census Bureau. ${ }^{13}$

The significant effect of manufacturing on inequality is not dependent on our measure of inequality or how the adjustments are made to create a measure of the residual wage variance. For the sake of simplifying the presentation, the remainder of the paper will focus on the measure of "residual inequality" used in column (4), since the goal is to understand the rise in inequality that is least understood in the existing literature.

Table 3 investigates the sensitivity of the findings in Table 2 to the inclusion or exclusion of various control variables. The first column controls for state and year

\footnotetext{
${ }^{13}$ The gini data is from: www.census.gov/hhes/www/income/data/historical/state/state4.html
} 
fixed-effects only, while the following columns progressively add controls for the mean average wage income, the age composition, and the education composition. In addition, the specification in column 5 includes state-specific linear time trends, while the final column uses control variables according to the respondent's state of birth rather than state of residence. The purpose of using state of birth is to abstract from the endogenous moving of respondents between states in response to the local level of inequality.

Across all specifications in Table 3, the coefficient on the manufacturing employment share is very stable in magnitude and significance, including the addition of state-specific time trends. These results demonstrate that the effect of the manufacturing sector on inequality is not sensitive to the choice of control variables, which supports the identifying assumption that the size of the manufacturing sector is not correlated with unobserved factors affecting the local level of residual inequality. Furthermore, the results are similar using state of birth instead of state of residence, which shows that endogenous moving in response to local inequality is not responsible for the main findings.

The coefficient on the manufacturing employment share is not only statistically significant, but sizable in magnitude. The aggregate decline in the manufacturing employment share was 15 percentage points from 1970 to 2010 (Figure 8). The coefficient in our main specification (column 4 in Table 3) is -0.913 which yields a predicted 0.149 increase in the 90/10 ratio. This increase is over half of the 0.26 increase in the aggregate 90/10 ratio of residual wages in Figure 4.

Table 4 examines whether the results are sensitive to the level of aggregation of the data. The first panel (left side) uses state-level data, but divides each state and year into two age groups: 25-39 years of age and 40-55 years of age. This analysis explains residual inequality defined by state and age group for each year with the percent of workers in manufacturing in each state and age group by year. The coefficient on the manufacturing share is very stable in terms of size and significance with no controls (except for fixed-effects for state, age group, and year), as well as adding the main control variables (mean wage, age composition of the state, education composition of the state), state-specific trends, and using state of birth to calculate the control variables.

The panel on the right side of Table 4 repeats the analysis at the city level (Metro Area). The advantage of aggregating at the city level is that our measures for 
the manufacturing employment share and residual inequality at the local level are more likely to be relevant for the same effective labor market relative to aggregating at the state level. The disadvantage of using cities is that it does not cover the entire United States, and therefore, could be affected by the rural-urban migration of manufacturing plants and workers. The results for the city-level analysis are very similar - a significant, negative coefficient that is not sensitive to the inclusion or exclusion of our main controls or city-specific time trends.

Table 5 examines whether the results for the manufacturing employment share are robust to the inclusion of other factors which have been highlighted in the literature on increasing inequality, technology, and the returns to education. This analysis is conducted at the state level and the state-age group level. A city-level analysis is not possible because some of these additional factors are not available at the city level. Our main specification (depicted in column (4) of Table 3) appears in the first column of each panel for comparison purposes when we add these additional controls.

The first additional control variable is the state-level return to a college education. Including this variable is designed to control for factors, such as skillbiased technological progress, which have been linked to increasing the return to education and are suspected to have increased residual inequality as well. Including the estimated return to college as a control variable does not affect the coefficient on the manufacturing share, despite the fact that states which experienced larger increases in residual inequality also had larger increases in the return to college (as seen by the positive, significant coefficient on the return to college in column (2)). However, since both of these measures may be influenced by the size of the manufacturing sector, our preferred specification does not include the return to college as an exogenously considered control variable. Another measure for technological progress at the local level that we use in Table 5 is the number of patents issued to residents of each state.

Table 5 also includes specifications with additional controls for the blue-collar employment share and the union density. These are likely to be correlated with the size of the manufacturing sector, and could be at least partly responsible for our main findings for the manufacturing share by having a direct effect on local inequality. For example, unions often strive to reduce inequality, and therefore, a decline in unionism in response to the decline in manufacturing could be driving our main results. Finally, 
measures for the state effective minimum wage (the maximum of the federal and the state minimum wage) are included directly and also relative to the state mean wage. A higher minimum wage could reduce inequality by propping up the bottom tail of the wage distribution.

Some of the variables mentioned above are not available for each year (19702010), so the results across specifications in Table 5 could differ due to the addition of a control variable or the change in the sample. However, the main coefficient of interest - the manufacturing employment share - is stable in terms of size and significance to the inclusion of all the additional controls and changes in the sample. This is true for both levels of aggregation. The coefficients on the additional controls are mostly in the expected direction and often significant. In particular, unions reduce inequality while the same is true for a higher minimum wage (relative to the state's mean wage). The prevalence of new patents is positively related to inequality, suggesting that a burgeoning high-tech sector increases wage dispersion. The bluecollar employment share is not significant in any specification for the state-level analysis. These findings should be considered with caution, since it is beyond the scope of this paper to identify the causal effect of each additional mechanism. The purpose of Table 5 is to see whether our findings for the manufacturing employment share are robust to including measures for alternative mechanisms highlighted in the literature. To that end, Table 5 displays no sensitivity at all for our main coefficient of interest.

The first two columns in Table 6 examine whether the decline in manufacturing is increasing inequality at the top or the low end of the wage distribution. For each of the three levels of aggregation (state, state by age groups, and cities), manufacturing has a significant effect on both the 50/10 ratio of residual wages and the 90/50 ratio. However, the estimated effect on the lower tail of the distribution is considerably larger.

Columns (3) to (8) in Table 6 investigate whether the results are sensitive to the starting date of the sample. The estimates are very similar to including all years in the sample (1970 to 2010), or starting the sample in 1980 or 1990 . This is true for the specifications with or without state or city-specific time trends.

To further support the causal interpretation of our estimates, Table 6 conducts an IV estimation by using an instrument for the local manufacturing employment share over time. The instrument predicts the local employment share from two 
sources of information: (1) the initial composition of workers across industries within manufacturing in locality $i$ (state or city) in the base year $t_{0}$; and (2) the aggregate employment shares of workers across industries over time for the whole United States. Formally, the predicted employment share is computed by:

$$
\widehat{M F G}_{\imath t}=\sum_{j=1}^{J} \pi_{j, i, t_{0}}\left(P_{j, t}-P_{j, t_{0}}\right)
$$

where $\pi_{j, i, t_{0}}$ is the employment share of industry $j$ in city $i$ in the base year $t_{0}$, and $P_{j, t}$ is the national employment share (excluding the workers in city $i$ ) of industry $j$ in year $t$ (including the base year $t_{0}$ ).

This IV strategy is based on the idea that a national decline in a certain industry will affect areas where this industry was heavily concentrated in the initial period, relative to the rest of the country. In addition, the national decline in any particular industry is considered to be exogenous to the unobserved local factors affecting an area's inequality level over time. This instrument was developed in Bartik (1991) and Blanchard and Katz (1992), and was used recently in the literature to instrument for the local level of manufacturing decline (Charles, Hurst, and Notowidigdo (2013)).

Table 6 presents the IV results for different time periods - each one having a different base year (1970, 1980 or 1990) and ending in the year 2010. The analysis is performed with and without locality-specific (state or MA) time trends. The first stage regressions (not shown in Table 6) indicate that the instrument is highly correlated with the actual manufacturing employment share. Specifically, the tstatistics on the instrument in the first stage for the state-level analysis are 9.60, 11.05, and 4.96 for starting dates 1970, 1980, and 1990 respectively. The first stage tstatistics for the state-level specifications which include state-specific time trends are $5.75,7.26$, and 3.33 for the same respective starting dates. Therefore, although the instrument is powerful, it weakens when the starting period is later and when locationspecific time periods are included.

The IV coefficients in Table 6 are very similar in magnitude and significance to the OLS estimates. This pattern is especially true for the specifications which start at 1970 or 1980 . Using 1990 as the base year and including location-specific time trends makes the results a bit more unstable, but as noted above, these are the cases 
where the instrument becomes weaker in the first stage. Overall, the IV results confirm the overall findings of the OLS analysis, which once again adds further support for the causal interpretation of the estimates.

\section{The Impact of Low-Skilled Immigration on Inequality}

The last several decades witnessed a decline in manufacturing employment and an increase in inequality, but at the same time, an influx of low-skilled immigrants altered the demographics of the labor market in a substantial way. Figure 14 illustrates this trend by showing that the share of non-college graduate immigrants in the population more than doubled in the last four decades (0.053 in 1970 to 0.150 in 2010). Appendix Figure 7 shows that this increase occurred in almost every state, but in degrees which vary considerably. This section exploits this geographic variation in order to examine whether this supply shift in less-educated labor exerted pressure on the low end of the wage distribution, thereby increasing the overall dispersion of wages.

Table 7 performs an analysis identical to the one above for the effect of the manufacturing sector on inequality, but adds the share of the population who are noncollege graduate immigrants as an additional treatment variable of interest. Adding this variable has no effect on the coefficient on manufacturing in columns (1) to (3), most likely because the local influx of immigrants is uncorrelated with the local decline in manufacturing (Appendix Figure 8).

The lack of any direct effect of immigrants on native wages in columns (1) to (3) in Table 7 is consistent with the existing literature that exploits geographic variation as an estimation strategy (Card (2001, 2005, 2009). However, existing work has not used as many Census years in the analysis, and focused on explaining inequality between education groups (i.e. the college wage premium) rather than inequality within groups (residual inequality).

However, it is possible that the impact of a surge in immigration interacts with the size of the manufacturing sector. As stated above, a large influx of immigrants may be more easily absorbed into the local labor market with minimal wage pressure on native workers if the local manufacturing sector is robust. In addition, Lewis (2009) argues that an influx of immigrants leads manufacturing firms to invest less in labor-saving equipment and technology, thus perhaps mitigating the effect of 
immigration on the wages of less-skilled workers. One could infer from this idea that the extent of the mitigating effect should depend on the size of the manufacturing sector. In areas where there is a large manufacturing sector, an influx of immigrants can more easily be absorbed with limited downward pressure on wages if firms increasingly utilize labor-intensive technologies. In areas with limited manufacturing jobs, an influx of low skilled immigrants should create more downward pressure on the wages of native workers that are more likely to compete with immigrants for lower paying service sector jobs.

To test this hypothesis, columns (4) to (6) in Table 7 include an interaction between the share of employment in manufacturing and the share of non-college graduate immigrants in the population. For all three levels of aggregation, Table 7 reveals a striking pattern whereby the immigrant share is positive and significant, and the interaction term is negative and significant. These coefficients suggest that in influx of less-educated immigrants increases inequality, but the effect decreases with the size of the manufacturing sector's employment share. These findings support the hypothesis that a robust manufacturing sector mitigates the negative impact of immigration on native wages.

The last three columns of Table 7 perform the same analysis but with instrumental variables. Each regression instruments for all three potentially endogenous control variables: the manufacturing share of employment, the share of non-college immigrants in the local population, and the interaction between the two. The instrument for the manufacturing employment share is the same as described above. The share of immigrants in the local population is based on the same idea as the instrument for manufacturing. Following several studies in the immigration literature (Card (2001, 2005, 2009), the instrument is constructed by using the crosssectional shares of immigrants from various countries across geographic units in the United States in the base year, along with the national trends in the share of immigrants from various countries. Essentially, the formula for the instrument is depicted by equation (2), with $j$ now referring to immigrants from country of origin $j$ instead of industry $j .^{14}$

After instrumenting for all three variables of interest, the results in the last three columns of Table 7 are similar to those obtained using OLS instead of IV. The

\footnotetext{
14 The instrument for the interaction of the manufacturing share and the immigrant share is the interaction of the instruments described above for each one.
} 
size, direction, and significance of each coefficient in each specification are very comparable, and confirm the idea that immigration does affect inequality, but in a way that depends on the size of the manufacturing sector. One could also interpret this from the other direction: the effect of manufacturing on inequality is strong and negative (less manufacturing jobs increase inequality), but this effect increases with the size of the immigrant population. In other words, the downward pressure on wages in response to a decline in manufacturing will be greater if there is also supply side pressure in the same direction. This effect could be due to the endogenous choice of technology by manufacturing firms. But, it could also be exacerbated by the overall fall in the demand for middle-skilled jobs, along with the increased supply of labor for lower skilled jobs due to immigration and the outflow of natives from relatively well-paid manufacturing work.

This interpretation, however, implies that the decline in manufacturing and the influx of low-skilled immigrants are affecting inequality by putting downward pressure on the low end of the wage distribution. This hypothesis is tested in Tables 8 and 9. Table 8 examines inequality at the top of the distribution (the 90/50 residual wage ratio) and Table 9 which examines the bottom of the distribution (the 50/10 ratio). Although there are some statistically significant coefficients for inequality at the top tail in Table 8, the estimates are much larger, significant, and robust across specifications and levels of aggregation in Table 9. These findings confirm the idea that the decline in manufacturing employment and the rise in low-skilled immigration are putting downward pressure on the wages of less-skilled natives.

\section{Employment Rates and the College Premium}

This section analyzes two additional measures of income inequality: the employment rate of non-college educated white men of prime working age, and the "college premium." The goal is to test the robustness of our findings with these alternative measures, and also to provide the first evidence that links all three phenomena to each other. Juhn (1992) argued that greater inequality reduces the labor supply of workers at the low end of the wage distribution, as potential wages fall below the reservation wage for many workers on the lower end of the distribution. But, no empirical evidence has linked the residual inequality trend with the increase in 
the return to education, although they are widely suspected to be driven by skillbiased technological change.

In addition, since our inequality measures in the previous section are computed for a sample of full-time workers, it is possible that our findings understate the true impact of the manufacturing sector and the immigrant share on inequality. This could occur, for example, if both of these treatment variables are causing a reduction in the employment rate of individuals who would typically be at the bottom of the wage distribution. If workers at the bottom of the distribution drop out of the labor market in response to the decline in manufacturing jobs, then the measured increase in the 90/10 ratio among full-time workers would be increasingly truncated at the bottom of the distribution. Under this scenario, our previous findings would understate the true effect of manufacturing and immigration on inequality.

Table 10 examines the employment rate of non-college educated white men, while Table 11 analyzes the estimated "college premium" for each level of aggregation. The first three columns of Table 10 indicate a strong direct effect of both treatment variables of interest on the employment rate. These estimates suggest that employment rates decline as the manufacturing sector shrinks and the immigrant share rises. Adding the interaction term in the next three columns reinforces our findings that these two phenomena interact with each other to affect inequality. The right side of Table 10 finds similar results using the IV strategy described above.

Overall, Table 10 presents additional evidence that the decline in manufacturing and the influx of immigrants are interacting to put downward pressure on the wages of the less-skilled men. This interpretation provides a consistent explanation for the employment rate results in Table 10, along with the stronger effects previously found for inequality at the bottom versus the top of the wage distribution in Tables 8 and 9. An increase in lower tail inequality should manifest itself in lower employment rates, and furthermore, the lower employment rates due to manufacturing and immigration are likely causing an understatement of the estimates on wage inequality since the lower tail of the wage distribution is increasingly truncated due to the same treatment variables. In other words, the decline in manufacturing and the influx of immigrants are reducing measured inequality by truncating the bottom of the wage distribution, so that our findings that they increase inequality are probably biased towards zero. 
Table 11 uses the estimated “college premium” for each locality as the outcome variable, instead of residual inequality or the employment rate. Overall, a familiar pattern emerges: a shrinking manufacturing sector increases the return to college, and more low-skilled immigration increases it. These results are found using OLS and IV, although the direct effects of both tend to be stronger than the interaction between the two treatment variables of interest. But, once again, the manufacturing and immigration trends are linked to an alternative measure of inequality, and it is worth pointing out that all three measures of inequality are using very different sources of variation. The college premium exploits the wage gaps between education groups, while the residual inequality measure abstracts from this variation completely. The residual inequality and college premium measures are using variation within workers with a strong attachment to the labor force, while the employment rate is exploiting variation in the size of the population not working on a regular basis (i.e. deleted from the inequality sample). So, the strikingly similar pattern of results across all three distinct measures of inequality provides a useful robustness check, and presents the first evidence that links all three outcomes together through their dependence on the manufacturing sector and the immigrant share.

\section{Using Commuting Zones and the "China Syndrome” Instrument}

A recent paper by Autor, Dorn, and Hanson (2013) (referred hereafter as “ADH”) used a similar empirical strategy by exploiting geographic variation across commuting zones in the United States to show that rising import competition from China increased unemployment while reducing labor force participation and wages. The authors measured the local exposure to Chinese imports using variation across commuting zones in their initial industrial composition, while instrumenting for US imports with changes in imports from China by other high income countries. ADH did not examine the effect of Chinese imports on measures for inequality, and the rise in Chinese imports beginning in the early 1990's cannot explain the secular decline in the manufacturing since the early 1970's. So, the rise in imports from China cannot explain the results presented above linking the decline in manufacturing and the surge in immigration to the inequality trend since the early 1970’s. 
However, ADH showed that increased import competition from China reduced the local size of the manufacturing sector, so their instrument can be used as an IV for changes in the size of the local manufacturing sector after 1990 in our analysis. To do this, the data and variables used until now were constructed at the commuting zone level, while merging variables from $\mathrm{ADH}$ for the local manufacturing share of male employment and their instrument for the local exposure to Chinese imports mentioned above. In addition, we made a few other adjustments to conform to their analysis: abbreviating the time period (1990-2010) and using a “difference" regression specification instead of locality fixed-effects.

The analysis at the commuting zone level is presented in Table 12. The top panel uses the manufacturing share variable from $\mathrm{ADH}$ while the bottom panel uses the same one in previous tables (at the commuting zone level). In both panels, the instrument for the given manufacturing variable comes from $\mathrm{ADH}$ using the local exposure to Chinese imports (using changes in imports from China by other high income countries), and the instrument for low-skilled immigration is the same "shiftshare” instrument used in previous tables. While the first stage is strong for both, the instrument for the interaction was not sufficiently strong (the t-statistics were below 3 for all three instruments in all three first stage regressions). Therefore, the results are presented for specifications without the interaction term.

The OLS results in Table 12 show once again that a shrinking manufacturing sector increases inequality at the commuting zone level during this truncated time period, as does an influx of low-skilled immigrants. Significant estimates are also obtained for the employment rate of non-college men. The IV results show a similar pattern, although the coefficient for the manufacturing sector is not significant for the overall level of inequality. However, the IV results using the ADH instrument are significant for inequality at the low end of the wage distribution (50/10 ratio) and for the employment rate. The latter two findings are consistent with manufacturing having a significant effect on low wage workers, even though the two outcomes are measured in very distinct ways as discussed above. Overall, the results in Table 12 reinforce the conclusion that inequality is indeed rising due to manufacturing decline and the rise of less-skilled immigrants - despite all the changes to the time period, data, variables, specification, and the instrument for manufacturing. 


\section{A Simple Demonstration of the Interaction and the Size of the Effects}

This section discusses the size of the effects and presents a very simple analysis to demonstrate the interaction between manufacturing and immigration on inequality. The estimated effects in our main analysis above are not only significant in the statistical sense, but also in magnitude. Between 1970 and 2010, the national manufacturing employment share decreased by 15.0 percentage points and the share of non-college immigrants increased by 9.7 percentage points. The implied effect of these changes on the 90/10 residual wage ratio according to the estimates in column (4) of Table 7 is equal to 0.22 . The predicted increase of 0.22 represents most of the increase in the 90/10 residual wage ratio at the aggregate level, which stands at 0.26. The predicted effect on non-college employment rates using the estimates in column (4) of Table 10 is a decline of 9.3 percentage points which is over two-thirds of the actual decline of 13.4. These findings suggest that the decline in manufacturing and the influx of low-skilled immigration are major determinants of the increase in residual wage inequality over time.

Interestingly, there is no correlation between the local decline in manufacturing and the influx of low-skilled immigrants. Appendix Figure 8 displays no significant relationship between the two at the state level. However, the states that experienced large shifts in both phenomena are clearly different in terms of their inequality and employment trends from states that were largely untouched by both. Table 13 divides all states into one of four categories according to whether they were above or below the median in terms of the decline in the state's manufacturing employment share and the increase in the state's share of non-college immigrants. The four categories are: (1) below the median for both shocks (decline in manufacturing and increase in non-college immigration); (2) below the median for manufacturing but above the median for immigration; (3) above the median for manufacturing but below the median for immigration; and (4) above the median for both. Groups (1) and (4) are the most different in terms of what they experienced, while the middle two groups were affected by a large shock in one dimension but a smaller shock in the other.

Figure 15 examines whether these groups are not only different in terms of their shocks, but also in their inequality outcomes. The pattern is quite striking: residual inequality in the group of states that experienced big shocks in both 
dimensions increased by 0.207 , while inequality in states with small shocks in both dimensions increased by only 0.111 on average. The increase in the other two groups, which witnessed a big shock in only one dimension, lies in the middle of the two extremes. Similar findings are displayed for the employment rates of non-college native men in Figure 16. The employment rates in states that experienced small shocks in both dimensions declined by 4.9 percentage points, while the employment rates in states that underwent large shocks in both declined by 9.9 percentage points. Again, the other states lie in between the two extremes. These patterns illustrate in a simple way how the interaction between the two types of shocks affected local inequality and employment rates.

\section{Conclusion}

The last four decades have witnessed a dramatic change in the wage and employment structure in the United States and many other developed countries. The wage gap between earners at the top versus the bottom of the distribution have widened, and research has been unable to explain this transformation with changes in the quantities or the returns to observable factors like education, experience, occupation, and industry. At the same time, the manufacturing sector has steadily declined, while less-skilled immigrants have increasingly become a larger proportion of the population in the United States.

This paper has revealed a striking pattern whereby states and cities that underwent the largest decline in the manufacturing sector also experienced the largest increase in wage inequality - including the "unexplained" portion of the wage variance. This relationship is robust to the inclusion or exclusion of a large set of control variables - including state or city-specific time trends. In addition, an IV analysis is conducted using information on the initial industrial shares across locations in the base period, and the national trends in industrial shares over time. This instrument is commonly used as an instrument for geographic variation in the size of the manufacturing sector over time, and this analysis confirms the causal interpretation of our results.

One interpretation for these findings is that the decline in the manufacturing sector has affected the distribution of earnings not only by workers shifting to 
alternative sectors, but also through a general equilibrium effect on the variation of wages within all sectors. The decline in the demand for mid-to-low educated workers who earned high relative wages served to hollow-out the middle of the wage distribution, while the shift to lower-paid service jobs generated a supply shock that put downward pressure on the wages of less-skilled workers in all sectors. The decline in the demand for skilled jobs in the manufacturing sector could have also increased wage dispersion in all sectors by reducing the possibilities for workers to pursue their comparative advantage by finding work in the manufacturing sector (Gould (2002, 2005).

The analysis also reveals a significant role for the influx of less-skilled immigrants on the inequality trends. Although the direct effect of immigration on inequality is not significant, the analysis shows that there is an important interaction between the size of the local manufacturing employment share and the share of noncollege graduate immigrants in the local population. The results show that an influx of less-educated immigrants increases inequality, especially in areas that are undergoing manufacturing decline. A similar interaction is shown to affect the employment rate of non-college graduate native men - an increase in immigration coupled with a decline in manufacturing lowers the employment rate of less-educated men. The similarity of the results for inequality and the employment rate of noncollege men reinforce the interpretation that these two phenomena are putting downward pressure on the wages of less skilled men - thus increasing inequality primarily at the bottom half of the wage distribution and encouraging more and more men to drop out of the labor market altogether.

The results regarding this interaction are robust across different specifications, time periods, and three different measures of inequality: the residual 90/10 ratio in log wages, the employment rate of non-college men, and the return to college. Also, similar results are found using the commonly used "shift-share" instruments for the size of the local manufacturing sector and the local share of immigrants - as well as using the "China Syndrome" instrument for the local manufacturing sector from Autor, Dorn, and Hanson (2013).

Overall, these findings support the recent literature that has found that increased trade from China has created important changes in the wages of workers inside of the tradable sector and in other sectors. However, the literature on the trade effects with China has not looked at inequality per se and has examined the post-1990 
period only. This paper has focused on inequality, and the inequality trend which started in the 1970's. Our findings complement the existing research on how observable measures of technological change have increased the return to education and also created a "polarization" of the workforce as workers shift out of relatively well-paying, but highly routinized jobs that could be replaced by new technologies like computers and advanced machines. This process led workers into lower-skill service jobs or highly skilled occupations. These occupational shifts have significantly altered the labor market, but have not been linked to increasing wage variation within occupations and industries.

This paper establishes an important link between inequality within all sectors and the general equilibrium impact of manufacturing decline and an influx of lessskilled immigration. These two phenomena, which do not appear to be related to one another (Appendix Figure 8), generated a decline in the overall demand for middleskilled work and an increase in the supply of workers looking to work in less-skilled jobs. As a result, variation in the extent to which a city or state experienced either one of these phenomena explains a large proportion of why the "unexplained" level of inequality increased over time. 


\section{References}

Acemoglu, Daron and David Autor. "Chapter 12 - Skills, Tasks and Technologies: Implications for Employment and Earnings,” In: David Card and Orley Ashenfelter, Editors, Handbook of Labor Economics, Elsevier, 2011, Volume 4, Part B, Pages 1043-1171.

Autor, David H., and David Dorn. 2013. "The Growth of Low-Skill Service Jobs and the Polarization of the US Labor Market." American Economic Review, 103(5): 1553-97.

Autor, David H., David Dorn, and Gordon H. Hanson. 2013a. "The China Syndrome: Local Labor Market Effects of Import Competition in the United States." American Economic Review, 103(6): 2121-68.

Autor, David H., David Dorn and Gordon H. Hanson. 2013b. "Untangling Trade and Technology: Evidence from Local Labor Markets,” NBER Working Paper 18938.

Autor, David H., David Dorn, and Gordon H. Hanson. "The Geography of Trade and Technology Shocks in the United States.” American Economic Review 103.3 (2013): 220-25.

Autor, David H., David Dorn, Gordon H. Hanson, and Jae Song. 2013. “Trade Adjustment: Worker Level Evidence,” NBER Working Paper No. 19226, July 2013. Quarterly Journal of Economics, forthcoming.

Autor, David H., Lawrence F. Katz and Melissa S. Kearney (2008) "Trends in U.S. Wage Inequality: Revising the Revisionists," Review of Economics and Statistics, 90(2): 300-323.

Autor, David H., Lawrence F. Katz and Alan Krueger . "Computing Inequality: Have Computers Changed the Labor Market?” Quarterly Journal of Economics, 113 (4), November 1998, 1169-1214.

Autor, David H., Frank Levy, and Richard J. Murnane. 2003. "The Skill Content of Recent Technological Change: An Empirical Investigation,” Quarterly Journal of Economics 118 (November 2003), 1279-1333.

Baily, Martin Neil, and Barry P. Bosworth. 2014. "US Manufacturing: Understanding Its Past and Its Potential Future." Journal of Economic Perspectives, 28(1): 326.

Bartik, Timothy (1991). "Who Benefits From State and Local Economic Development Policies,” W.E. Upjohn Institute for Employment Research: Kalamazoo, Mich.

Blanchard, Olivier and Lawrence F. Katz (1992). "Regional Evolutions,”” Brookings Papers on Economic Activity, 23(1): 1-76. 
Beaudry, Paul, Mark Doms, and Ethan Lewis. "Should the Personal Computer Be Considered a Technological Revolution? Evidence from U.S. Metropolitan Areas.” Journal of Political Economy 118.5 (2010): 988-1036

Berman, Eli, John Bound, and Zvi Griliches. "Changes in the Demand for Skilled Labor within U.S. Manufacturing: Evidence from the Annual Survey of Manufacturers,” Quarterly Journal of Economics, Vol. 109, No. 2 (May, 1994), pp. 367-397

Berman, Eli, John Bound, and Stephen Machin, 1998. "Implications Of Skill-Biased Technological Change: International Evidence," Quarterly Journal of Economics, 113(4), 1245-1279, November.

Bloom, Nicholas, Mirko Draca, and John Van Reenen. 2009. “Trade Induced Technical Change? The Impact of Chinese Imports on Diffusion, Innovation, and Productivity.” Mimeo, Stanford University.

Borjas, George J. (2003). "The labor demand curve is downward sloping: reexamining the impact of immigration on the labor market” Quarterly Journal of Economics, 118, 1335-74.

Borjas, George J., Richard B. Freeman, and Lawrence F. Katz. (1997). "How Much Do Immigration and Trade Affect Labor Market Outcomes?" Brookings Papers on Economic Activity, 1: 1-67.

Borjas, George, Jeffrey Grogger, and Gordon H. Hanson. (2010). "Immigration and the Economic Status of African-American Men,” Economica, 77, 255-282.

Bound, John, and Holzer, Harry J. "Industrial Structure, Skill Levels, and the Labor Market for White and Black Males.” Review of Economics and Statistics 75 (August 1993): 387-96.

Bound, John and Harry J. Holzer. 2000. "Demand Shifts, Population Adjustments, and Labor Market Outcomes during the 1980s,” Journal of Labor Economics, 18(1): 20-54.

Card, David. (2001). "Immigrant Inflows, Native Outflows, and the Local Labor Market Impacts of Higher Immigration.” Journal of Labor Economics, 19(1): 22-64.

Card, David. (2005). "Is the New Immigration Really So Bad?” Economic Journal, 115(507): F300-23.

Card, David. (2009). "Immigration and Inequality," American Economic Review: Papers \& Proceedings, 99:2, 1-21.

Charles, Kerwin Kofi, Erik Hurst, Matthew J. Notowidigdo. "Manufacturing Decline, Housing Booms, and Non-Employment,” NBER Working Paper No. 18949, April 2013. 
Cortés, Patricia, and José Tessada. 2011. "Low-Skilled Immigration and the Labor Supply of Highly Skilled Women." American Economic Journal: Applied Economics, 3(3): 88-123.

Dustmann, Christian, Tommaso Frattini, and Ian P. Preston, 2013. "The Effect of Immigration along the Distribution of Wages," Review of Economic Studies, 80(1), pages $145-173$.

Ebenstein, Avraham, Ann Harrison, Margaret McMillan, and Shannon Phillips. Forthcoming. 2013. "Estimating the Impact of Trade and Offshoring on American Workers Using the Current Population Surveys." Review of Economics and Statistics.

Friedberg Rachel M. (2001). "The Impact of Mass Migration on the Israeli Labor Market,” Quarterly Journal of Economics, 116(4): 1373-1408

Friedberg, Rachel M. and Hunt, Jennifer (1995). "The Impact of Immigration on Host Country Wages, Employment, and Growth," Journal of Economic Perspectives, vol. 9 (Spring), pp. 23-44.

Goos, Maarten and Alan Manning, 2007. "Lousy and Lovely Jobs: The Rising Polarization of Work in Britain," Review of Economics and Statistics, 89(1), 118-133, February.

Gould, Eric D., 2002. "Rising Wage Inequality, Comparative Advantage, and the Growing Importance of General Skills in the United States," Journal of Labor Economics, 20(1), January, 105-147.

Gould, Eric D., 2005. “Inequality and ability,” Labour Economics, 12(2), April, 169189.

Juhn, Chinhui, (1992). "Decline of Male Labor Market Participation: The Role of Declining Market Opportunities,” Quarterly Journal of Economics, 107 (1), 79-121.

Juhn, Chinhui, Kevin M. Murphy, and Brooks Pierce, “Wage Inequality and the Rise in Returns to Skill,” Journal of Political Economy, 1993, vol. 101.

Katz, Lawrence F. and Kevin M. Murphy, "Changes in Relative Wages, 1963-1987: Supply and Demand Factors,” Quarterly Journal of Economics, February 1992.

Lee, David S., "Wage Inequality in the U.S. during the 1980s: Rising Dispersion or Falling Minimum Wage?” Quarterly Journal of Economics 114 (August 1999), 977-1023.

Lemieux, Thomas. 2006. "Increasing Residual Wage Inequality: Composition Effects, Noisy Data, or Rising Demand for Skill?" American Economic Review, 96(3): 461-498. 
Lewis, Ethan. 2011. “Immigration, Skill Mix, and Capital Skill Complementarity,” Quarterly Journal of Economics (2011) 126 (2): 1029-1069.

Lindley, Joanne and Stephen Machin. "Spatial changes in labour market inequality," Journal of Urban Economics, 2013, forthcoming.

Machin, Stephen and John Van Reenen, 1998. "Technology And Changes In Skill Structure: Evidence From Seven OECD Countries," Quarterly Journal of Economics, MIT Press, vol. 113(4), pages 1215-1244, November.

Michaels, Guy, Ashwini Natraj, and John Van Reenen. 2014. "Has ICT Polarized Skill Demand? Evidence from Eleven Countries over Twenty-Five Years," Review of Economics and Statistics, March 2014, 96(1): 60-77.

Moretti Enrico, “Chapter 14 - Local Labor Markets”, In: David Card and Orley Ashenfelter, Editors, Handbook of Labor Economics, Elsevier, 2011, Volume 4, Part B, Pages 1237-1313.

Moretti, Enrico. 2010. "Local Multipliers." American Economic Review, 100(2): 37377.

Murphy, Kevin M., and Finis Welch, “The Structure of Wages,” Quarterly Journal of Economics 107 (February 1992), 285-326.

Ottaviano, Gianmarco I. P. and Giovanni Peri, 2012. "Rethinking the Effect of Immigration On Wages," Journal of the European Economic Association, 10(1), February, 152-197.

Ruggles, Steven, Matthew Sobek, Trent Alexander, Catherine A. Fitch, Ronald Goeken, Patricia Kelly Hall, Miriam King, and Chad Ronnander. 2010. Integrated Public Use Microdata Series: Version 3.0 [Machine-readable database]. Minneapolis, MN: Minnesota Population Center [producer and distributor].

Van Reenen, John, 2011. "Wage inequality, technology and trade: 21st century evidence," Labour Economics, 18(6), pages 730-741. 
Table 1: Descriptive Statistics for State-Level Analysis



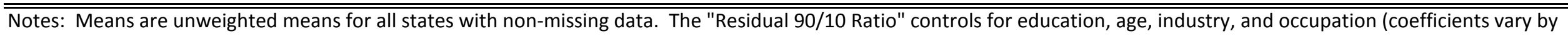
year). 
Table 2: State-Level Analysis of Inequality and Manufacturing

\begin{tabular}{|c|c|c|c|c|c|c|}
\hline & Total 90/10 & $\begin{array}{l}\text { 90/10 Adjust for Age } \\
\text { and Educ }\end{array}$ & $\begin{array}{c}\text { 90/10 Adjust for Age } \\
\text { and Educ } \\
\text { (Unrestricted } \\
\text { Coefficients) }\end{array}$ & $\begin{array}{l}\text { "Residual Inequality" } \\
\text { (90/10 Adjust for Age, } \\
\text { Educ, Occupation, } \\
\text { Industry with } \\
\text { Unrestricted } \\
\text { Coefficients) }\end{array}$ & $\begin{array}{l}\text { "Residual Inequality" } \\
\text { outside of MFG Sector }\end{array}$ & Gini Coefficient \\
\hline & (1) & (2) & (3) & (4) & (5) & (6) \\
\hline$\%$ Manufacturing & $\begin{array}{c}-1.139 * * * \\
(0.178)\end{array}$ & $\begin{array}{c}-0.886 * * * \\
(0.164)\end{array}$ & $\begin{array}{c}-0.873^{* * *} \\
(0.165)\end{array}$ & $\begin{array}{c}-0.913^{* * *} \\
(0.145)\end{array}$ & $\begin{array}{c}-0.778^{* * *} \\
(0.141)\end{array}$ & $\begin{array}{c}-0.215^{* * *} \\
(0.027)\end{array}$ \\
\hline Log Mean Wage Income & $\begin{array}{c}0.036 \\
(0.100)\end{array}$ & $\begin{array}{c}0.264 * * * \\
(0.064)\end{array}$ & $\begin{array}{c}0.203 * * * \\
(0.063)\end{array}$ & $\begin{array}{c}0.198 * * * \\
(0.059)\end{array}$ & $\begin{array}{c}0.211^{* * *} \\
(0.067)\end{array}$ & $\begin{array}{c}0.037 \\
(0.024)\end{array}$ \\
\hline$\%$ between 35 and 44 Years of Age & $\begin{array}{c}0.360 \\
(0.312)\end{array}$ & $\begin{array}{c}0.415 \\
(0.263)\end{array}$ & $\begin{array}{l}0.497^{*} \\
(0.271)\end{array}$ & $\begin{array}{c}0.321 \\
(0.228)\end{array}$ & $\begin{array}{c}0.227 \\
(0.278)\end{array}$ & $\begin{array}{c}0.033 \\
(0.055)\end{array}$ \\
\hline$\%$ between 45 and 55 Years of Age & $\begin{array}{l}-0.060 \\
(0.257)\end{array}$ & $\begin{array}{l}-0.190 \\
(0.232)\end{array}$ & $\begin{array}{l}-0.063 \\
(0.236)\end{array}$ & $\begin{array}{l}-0.290 \\
(0.208)\end{array}$ & $\begin{array}{c}-0.358 \\
(0.225)\end{array}$ & $\begin{array}{c}0.064 \\
(0.039)\end{array}$ \\
\hline \% High School Graduates & $\begin{array}{c}-1.118^{* * *} \\
(0.200)\end{array}$ & $\begin{array}{c}-0.726^{* * *} \\
(0.158)\end{array}$ & $\begin{array}{c}-0.753^{* * *} \\
(0.154)\end{array}$ & $\begin{array}{c}-0.847^{* * *} \\
(0.159)\end{array}$ & $\begin{array}{c}-0.885^{* * *} \\
(0.146)\end{array}$ & $\begin{array}{c}-0.088^{* * *} \\
(0.032)\end{array}$ \\
\hline$\%$ College Graduates & $\begin{array}{c}-0.989 * * * \\
(0.335)\end{array}$ & $\begin{array}{c}-1.021 * * * \\
(0.277)\end{array}$ & $\begin{array}{c}-1.033^{* * *} \\
(0.253)\end{array}$ & $\begin{array}{c}-1.125^{* * *} \\
(0.280)\end{array}$ & $\begin{array}{c}-1.107^{* * *} \\
(0.304)\end{array}$ & $\begin{array}{l}-0.094 \\
(0.098)\end{array}$ \\
\hline Year Fixed-Effects & Yes & Yes & Yes & Yes & Yes & Yes \\
\hline State Fixed-Effects & Yes & Yes & Yes & Yes & Yes & Yes \\
\hline Observations & 243 & 243 & 243 & 243 & 243 & 200 \\
\hline Number of States & 50 & 50 & 50 & 50 & 50 & 50 \\
\hline
\end{tabular}

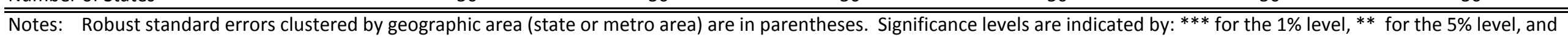

* for the $10 \%$ level. The gini coefficient is missing for 2010. Observations are weighted by the local population size in 1990. 
Table 3: Sensitivity of State-Level Analysis of Inequality and Manufacturing

Dependent Variable: Residual Inequality (90/10 Adjusted for Age, Educ, Occupation, Industry with Unrestricted Coefficients)

\begin{tabular}{|c|c|c|c|c|c|}
\hline (1) & (2) & (3) & (4) & (5) & (6) \\
\hline$-0.923 * * *$ & $-0.836 * * *$ & $-0.790 * * *$ & $-0.913 * * *$ & $-0.891 * * *$ & $-0.766 * * *$ \\
\hline \multirow[t]{11}{*}{$(0.152)$} & $(0.131)$ & $(0.141)$ & $(0.145)$ & $(0.263)$ & $(0.181)$ \\
\hline & $0.158^{* *}$ & $0.155^{*}$ & $0.198 * * *$ & 0.080 & $0.303^{* * *}$ \\
\hline & $(0.078)$ & $(0.081)$ & (0.059) & (0.059) & $(0.094)$ \\
\hline & & 0.234 & 0.321 & $0.744 * * *$ & 0.175 \\
\hline & & $(0.269)$ & $(0.228)$ & $(0.230)$ & $(0.169)$ \\
\hline & & -0.166 & -0.290 & -0.013 & 0.062 \\
\hline & & $(0.224)$ & $(0.208)$ & (0.190) & $(0.134)$ \\
\hline & & & $-0.847^{* * *}$ & -0.283 & $-0.765 * * *$ \\
\hline & & & (0.159) & (0.339) & (0.137) \\
\hline & & & $-1.125^{* * *}$ & -0.289 & $-0.659 * * *$ \\
\hline & & & $(0.280)$ & (0.339) & $(0.212)$ \\
\hline Yes & Yes & Yes & Yes & Yes & Yes \\
\hline \multirow[t]{3}{*}{ Yes } & Yes & Yes & Yes & Yes & Yes \\
\hline & & & & Yes & \\
\hline & & & & & Yes \\
\hline 243 & 243 & 243 & 243 & 243 & 243 \\
\hline 50 & 50 & 50 & 50 & 50 & 50 \\
\hline
\end{tabular}

Year Fixed-Effects

State Fixed-Effects

State-Specific Linear Time Trends

Controls Computed at State of Birth

Observations

Notes: Robust standard errors clustere $\bar{d}$ by geographic area (state or metro area) are in parentheses. Significance levels are indicated

the $10 \%$ level. Observations are weighted by the local population size in 1990. 
Table 4: Analysis of Inequality and Manufacturing by State-Age Groups and by Metropolitan Areas

Dependent Variable: Residual Inequality (90/10 Adjusted for Age, Educ, Occupation, Industry with Unrestricted Coefficients)

\begin{tabular}{|c|c|c|c|c|c|c|c|c|c|c|c|}
\hline & \multicolumn{6}{|c|}{ State-Age Group Analysis } & \multicolumn{5}{|c|}{ MA-Level Analysis } \\
\hline & (1) & (2) & (3) & (4) & (5) & (6) & (7) & (8) & (9) & (10) & (11) \\
\hline$\%$ Manufacturing & $\begin{array}{c}-0.767^{* * *} \\
(0.107)\end{array}$ & $\begin{array}{c}-0.742^{* * *} \\
(0.096)\end{array}$ & $\begin{array}{c}-0.706^{* * *} \\
(0.102)\end{array}$ & $\begin{array}{c}-0.620 * * * \\
(0.108)\end{array}$ & $\begin{array}{c}-0.682^{* * *} \\
(0.147)\end{array}$ & $\begin{array}{c}-0.430 * * * \\
(0.149)\end{array}$ & $\begin{array}{c}-0.396^{* * *} \\
(0.099)\end{array}$ & $\begin{array}{c}-0.484^{* * *} \\
(0.099)\end{array}$ & $\begin{array}{c}-0.460 * * * \\
(0.096)\end{array}$ & $\begin{array}{c}-0.670 * * * \\
(0.099)\end{array}$ & $\begin{array}{c}-0.340^{* *} \\
(0.139)\end{array}$ \\
\hline Log Mean Wage Income & & $\begin{array}{c}0.180^{* * *} \\
(0.055)\end{array}$ & $\begin{array}{c}0.174^{* * *} \\
(0.059)\end{array}$ & $\begin{array}{c}0.212^{* * *} \\
(0.068)\end{array}$ & $\begin{array}{c}0.055 \\
(0.036)\end{array}$ & $\begin{array}{c}0.352^{* * *} \\
(0.066)\end{array}$ & & $\begin{array}{c}0.211^{* * *} \\
(0.068)\end{array}$ & $\begin{array}{c}0.202^{* * *} \\
(0.062)\end{array}$ & $\begin{array}{c}0.209 * * * \\
(0.072)\end{array}$ & $\begin{array}{c}0.164^{* * *} \\
(0.058)\end{array}$ \\
\hline$\%$ between 35 and 44 Years of Age & & & $\begin{array}{c}0.165 \\
(0.207)\end{array}$ & $\begin{array}{c}0.238 \\
(0.193)\end{array}$ & $\begin{array}{c}0.724^{* * *} \\
(0.172)\end{array}$ & $\begin{array}{c}0.489 * * \\
(0.189)\end{array}$ & & & $\begin{array}{l}0.274^{*} \\
(0.158)\end{array}$ & $\begin{array}{c}0.158 \\
(0.146)\end{array}$ & $\begin{array}{c}0.507^{* * *} \\
(0.169)\end{array}$ \\
\hline$\%$ between 45 and 55 Years of Age & & & $\begin{array}{l}-0.195 \\
(0.190)\end{array}$ & $\begin{array}{l}-0.194 \\
(0.184)\end{array}$ & $\begin{array}{l}-0.032 \\
(0.162)\end{array}$ & $\begin{array}{c}0.406^{* *} \\
(0.168)\end{array}$ & & & $\begin{array}{l}-0.148 \\
(0.157)\end{array}$ & $\begin{array}{l}-0.241 \\
(0.155)\end{array}$ & $\begin{array}{c}0.012 \\
(0.148)\end{array}$ \\
\hline$\%$ High School Graduates & & & & $\begin{array}{c}-0.222^{* *} \\
(0.103)\end{array}$ & $\begin{array}{c}0.228^{* * *} \\
(0.056)\end{array}$ & $\begin{array}{c}-0.366^{* * *} \\
(0.088)\end{array}$ & & & & $\begin{array}{c}-0.621^{* * *} \\
(0.114)\end{array}$ & $\begin{array}{l}-0.344 \\
(0.233)\end{array}$ \\
\hline$\%$ College Graduates & & & & $\begin{array}{l}-0.144 \\
(0.120)\end{array}$ & $\begin{array}{c}0.124 \\
(0.080)\end{array}$ & $\begin{array}{c}-0.291^{* *} \\
(0.111)\end{array}$ & & & & $\begin{array}{c}-0.715^{* * *} \\
(0.173)\end{array}$ & $\begin{array}{c}-0.561^{* *} \\
(0.236)\end{array}$ \\
\hline Age-Group Fixed-Effects & Yes & Yes & Yes & Yes & Yes & Yes & & & & & \\
\hline Year Fixed-Effects & Yes & Yes & Yes & Yes & Yes & Yes & Yes & Yes & Yes & Yes & Yes \\
\hline State or MA Fixed-Effects & Yes & Yes & Yes & Yes & Yes & Yes & Yes & Yes & Yes & Yes & Yes \\
\hline State or MA-Specific Linear Time Trends & & & & & Yes & & & & & & Yes \\
\hline Controls Computed at State of Birth & & & & & & Yes & & & & & \\
\hline Observations & 486 & 486 & 486 & 486 & 486 & 486 & 590 & 590 & 590 & 590 & 590 \\
\hline Number of States or MA's & 100 & 100 & 100 & 100 & 100 & 100 & 119 & 119 & 119 & 119 & 119 \\
\hline
\end{tabular}

Age-Group Fixed-Effects

Year Fixed-Effects

State or MA Fixed-Effects

State or MA-Specific Linear Time Trends

Controls Computed at State of Birth

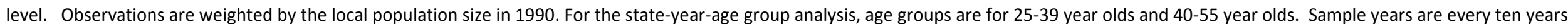

from 1970-2010. 
Dependent Variable: Residual Inequality (90/10 Adjusted for Age, Educ, Occupation, Industry with Unrestricted Coefficients)

\begin{tabular}{|c|c|c|c|c|c|c|c|c|c|c|c|c|c|}
\hline \multicolumn{7}{|c|}{ State-Level Analysis } & \multicolumn{7}{|c|}{ State-Age Group Analysis } \\
\hline (1) & (2) & (3) & (4) & (5) & (6) & (7) & (8) & (9) & (10) & (11) & $(12)$ & (13) & (14) \\
\hline $\begin{array}{c}-0.913 * * * \\
(0.145)\end{array}$ & $\begin{array}{c}-0.890 * * * \\
(0.140)\end{array}$ & $\begin{array}{c}-0.899 * * * \\
(0.214)\end{array}$ & $\begin{array}{c}-0.803^{* * *} \\
(0.177)\end{array}$ & $\begin{array}{c}-0.977^{* * *} \\
(0.155)\end{array}$ & $\begin{array}{c}-0.982^{* * *} \\
(0.169)\end{array}$ & $\begin{array}{c}-0.848^{* * *} \\
(0.167)\end{array}$ & $\begin{array}{c}-0.620^{* * *} \\
(0.108)\end{array}$ & $\begin{array}{c}-0.609 * * * \\
(0.108)\end{array}$ & $\begin{array}{c}-0.742^{* * *} \\
(0.136)\end{array}$ & $\begin{array}{c}-0.669 * * * \\
(0.138)\end{array}$ & $\begin{array}{c}-0.934 * * * \\
(0.115)\end{array}$ & $\begin{array}{c}-0.908^{* * *} \\
(0.126)\end{array}$ & $\begin{array}{c}-0.805^{* * *} \\
(0.117)\end{array}$ \\
\hline $\begin{array}{c}0.198^{* * *} \\
(0.059)\end{array}$ & $\begin{array}{c}0.204^{* * *} \\
(0.055)\end{array}$ & $\begin{array}{c}0.196 * * * \\
(0.065)\end{array}$ & $\begin{array}{c}0.316^{* * *} \\
(0.080)\end{array}$ & $\begin{array}{c}0.226 \\
(0.145)\end{array}$ & $\begin{array}{c}0.227 \\
(0.150)\end{array}$ & $\begin{array}{l}0.343^{* *} \\
(0.146)\end{array}$ & $\begin{array}{c}0.212^{* * *} \\
(0.068)\end{array}$ & $\begin{array}{c}0.196 * * * \\
(0.063)\end{array}$ & $\begin{array}{c}0.228^{* * *} \\
(0.069)\end{array}$ & $\begin{array}{c}0.306^{* * *} \\
(0.060)\end{array}$ & $\begin{array}{c}0.143 \\
(0.088)\end{array}$ & $\begin{array}{c}0.129 \\
(0.099)\end{array}$ & $\begin{array}{c}0.299 * * * \\
(0.097)\end{array}$ \\
\hline 0.321 & 0.282 & 0.322 & $0.708^{* * *}$ & $0.728 * * *$ & $0.725^{* * *}$ & $0.715^{* * *}$ & 0.238 & 0.211 & 0.226 & $0.700 * * *$ & $1.084^{* * *}$ & $1.079 * * *$ & $0.913^{* * *}$ \\
\hline$(0.228)$ & $(0.238)$ & $(0.230)$ & $(0.231)$ & (0.254) & $(0.253)$ & (0.254) & (0.193) & (0.197) & (0.194) & $(0.213)$ & (0.209) & (0.210) & $(0.206)$ \\
\hline $\begin{array}{l}-0.290 \\
(0.208)\end{array}$ & $\begin{array}{l}-0.360 \\
(0.231)\end{array}$ & $\begin{array}{l}-0.287 \\
(0.216)\end{array}$ & $\begin{array}{l}-0.104 \\
(0.167)\end{array}$ & $\begin{array}{c}-0.024 \\
(0.183)\end{array}$ & $\begin{array}{l}-0.015 \\
(0.175)\end{array}$ & $\begin{array}{l}-0.138 \\
(0.176)\end{array}$ & $\begin{array}{l}-0.194 \\
(0.184)\end{array}$ & $\begin{array}{l}-0.221 \\
(0.182)\end{array}$ & $\begin{array}{l}-0.224 \\
(0.177)\end{array}$ & $\begin{array}{c}0.086 \\
(0.146)\end{array}$ & $\begin{array}{c}0.160 \\
(0.148)\end{array}$ & $\begin{array}{c}0.076 \\
(0.171)\end{array}$ & $\begin{array}{l}-0.147 \\
(0.159)\end{array}$ \\
\hline $\begin{array}{c}-0.847^{* * *} \\
(0.159)\end{array}$ & $\begin{array}{c}-0.808 * * * \\
(0.136)\end{array}$ & $\begin{array}{c}-0.847^{* * *} \\
(0.158)\end{array}$ & $\begin{array}{c}-0.404^{* *} \\
(0.184)\end{array}$ & $\begin{array}{l}-0.192 \\
(0.194)\end{array}$ & $\begin{array}{l}-0.201 \\
(0.236)\end{array}$ & $\begin{array}{c}0.082 \\
(0.191)\end{array}$ & $\begin{array}{c}-0.222^{* *} \\
(0.103)\end{array}$ & $\begin{array}{c}-0.206^{* *} \\
(0.097)\end{array}$ & $\begin{array}{c}-0.252^{* *} \\
(0.108)\end{array}$ & $\begin{array}{c}0.019 \\
(0.103)\end{array}$ & $\begin{array}{c}0.212^{* *} \\
(0.093)\end{array}$ & $\begin{array}{c}0.232^{* *} \\
(0.091)\end{array}$ & $\begin{array}{c}0.271^{* * *} \\
(0.076)\end{array}$ \\
\hline$-1.125^{* * *}$ & $-1.108 * * *$ & $-1.144^{* * *}$ & $-1.152^{* * *}$ & $-1.090 * *$ & $-1.096 *$ & -0.875 & -0.144 & -0.071 & -0.013 & -0.087 & 0.162 & 0.170 & 0.019 \\
\hline \multirow[t]{9}{*}{$(0.280)$} & $\begin{array}{c}(0.252) \\
0.222^{* *} \\
(0.085)\end{array}$ & $(0.240)$ & (0.311) & (0.538) & (0.557) & (0.562) & (0.120) & $\begin{array}{c}(0.115) \\
0.120 \\
(0.075)\end{array}$ & (0.108) & $(0.102)$ & (0.157) & (0.163) & (0.164) \\
\hline & & $\begin{array}{l}-0.041 \\
(0.311)\end{array}$ & $\begin{array}{l}-0.077 \\
(0.308)\end{array}$ & $\begin{array}{c}0.112 \\
(0.227)\end{array}$ & $\begin{array}{c}0.110 \\
(0.223)\end{array}$ & $\begin{array}{c}0.161 \\
(0.225)\end{array}$ & & & $\begin{array}{l}0.345^{*} \\
(0.177)\end{array}$ & $\begin{array}{c}0.283 \\
(0.201)\end{array}$ & $\begin{array}{c}0.473 * * * \\
(0.176)\end{array}$ & $\begin{array}{l}0.468 * * \\
(0.180)\end{array}$ & $\begin{array}{c}0.400^{* *} \\
(0.175)\end{array}$ \\
\hline & & & $\begin{array}{c}-0.002^{* *} \\
(0.001)\end{array}$ & $\begin{array}{c}-0.003^{* *} \\
(0.001)\end{array}$ & $\begin{array}{c}-0.003^{* *} \\
(0.001)\end{array}$ & $\begin{array}{l}-0.002^{*} \\
(0.001)\end{array}$ & & & & $\begin{array}{c}-0.003^{* *} \\
(0.001)\end{array}$ & $\begin{array}{c}-0.003 * * * \\
(0.001)\end{array}$ & $\begin{array}{c}-0.003^{* * *} \\
(0.001)\end{array}$ & $\begin{array}{c}-0.002^{* *} \\
(0.001)\end{array}$ \\
\hline & & & & $5.434^{* * *}$ & $5.399 * * *$ & $5.852^{* * *}$ & & & & & $7.477^{* * *}$ & $7.607^{* * *}$ & $7.332^{* * *}$ \\
\hline & & & & $(0.887)$ & $(1.076)$ & $(0.896)$ & & & & & $(0.698)$ & $(0.769)$ & $(0.723)$ \\
\hline & & & & & $\begin{array}{l}-0.010 \\
(0.097)\end{array}$ & & & & & & & $\begin{array}{c}0.065 \\
(0.076)\end{array}$ & \\
\hline & & & & & & $1.385^{* *}$ & & & & & & & $1.884^{* * *}$ \\
\hline & & & & & & (0.639) & & & & & & & $(0.452)$ \\
\hline & & & & & & & Yes & Yes & Yes & Yes & Yes & Yes & Yes \\
\hline Yes & Yes & Yes & Yes & Yes & Yes & Yes & Yes & Yes & Yes & Yes & Yes & Yes & Yes \\
\hline Yes & Yes & Yes & Yes & Yes & Yes & Yes & Yes & Yes & Yes & Yes & Yes & Yes & Yes \\
\hline 243 & 243 & 243 & 200 & 149 & 149 & 149 & 486 & 486 & 486 & 400 & 298 & 298 & 298 \\
\hline 50 & 50 & 50 & 50 & 50 & 50 & 50 & 100 & 100 & 100 & 100 & 100 & 100 & 100 \\
\hline
\end{tabular}

$\%$ Manufacturing

Log Mean Wage Income

$\%$ between 35 and 44 Years of Age

$\%$ between 45 and 55 Years of Age

\% High School Graduates

\% College Graduates

Return to College

\% Blue Collar Workers

Union Density

Number of Patents

Minimum Wage

Minimum Wage/Average Wage

Age-Group Fixed-Effects

Year Fixed-Effects

State Fixed-Effects

Observations

Number of States or MA's

50

Signi

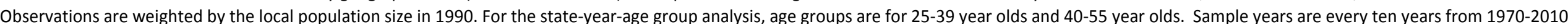

but some control variables are missing for certain years as indicated in Table 1. 
Table 6: Residual Inequality and Manufacturing (OLS, IV, and Inequality at the Top and Bottom)

\begin{tabular}{|c|c|c|c|c|c|c|c|c|c|c|c|c|c|c|}
\hline & \multirow{2}{*}{$\begin{array}{c}\begin{array}{c}\text { Residual } \\
90 / 50\end{array} \\
(1)\end{array}$} & \multirow{2}{*}{$\begin{array}{c}\begin{array}{c}\text { Residual } \\
50 / 10\end{array} \\
(2)\end{array}$} & \multicolumn{6}{|c|}{ Residual 90/10 -- OLS With Different Time Periods } & \multicolumn{6}{|c|}{ Residual 90/10 -- IV With Different Time Periods } \\
\hline & & & (3) & (4) & (5) & (6) & (7) & (8) & (9) & (10) & (11) & (12) & (13) & (14) \\
\hline \multirow[t]{2}{*}{ Starting Year } & 1970 & 1970 & 1970 & 1980 & 1990 & 1970 & 1980 & 1990 & 1970 & 1980 & 1990 & 1970 & 1980 & 1990 \\
\hline & \multicolumn{14}{|c|}{ Analysis by State and Year } \\
\hline$\%$ Manufacturing & $\begin{array}{c}-0.251^{* * *} \\
(0.077)\end{array}$ & $\begin{array}{c}-0.662 * * * \\
(0.084)\end{array}$ & $\begin{array}{c}-0.913^{* * *} \\
(0.145)\end{array}$ & $\begin{array}{c}-0.912^{* * *} \\
(0.142)\end{array}$ & $\begin{array}{c}-0.921 * * * \\
(0.247)\end{array}$ & $\begin{array}{c}-0.891 * * * \\
(0.263)\end{array}$ & $\begin{array}{c}-0.856 * * * \\
(0.312)\end{array}$ & $\begin{array}{c}-1.292^{* *} \\
(0.584)\end{array}$ & $\begin{array}{c}-0.780^{* * *} \\
(0.239)\end{array}$ & $\begin{array}{c}-0.934 * * * \\
(0.219)\end{array}$ & $\begin{array}{l}-0.245 \\
(0.502)\end{array}$ & $\begin{array}{c}-1.475^{* * *} \\
(0.572)\end{array}$ & $\begin{array}{c}-1.411^{* * *} \\
(0.410)\end{array}$ & $\begin{array}{c}-0.833 \\
(0.752)\end{array}$ \\
\hline Observations & 243 & 243 & 243 & 200 & 150 & 243 & 200 & 150 & 215 & 200 & 150 & 215 & 200 & 150 \\
\hline \multirow[t]{2}{*}{ Number of states } & 50 & 50 & 50 & 50 & 50 & 50 & 50 & 50 & 43 & 50 & 50 & 43 & 50 & 50 \\
\hline & \multicolumn{14}{|c|}{ Analysis by State, Age-Group, and Year } \\
\hline$\%$ Manufacturing & $\begin{array}{c}-0.147^{* *} \\
(0.059)\end{array}$ & $\begin{array}{c}-0.473^{* * *} \\
(0.069)\end{array}$ & $\begin{array}{c}-0.620^{* * *} \\
(0.108)\end{array}$ & $\begin{array}{c}-0.660^{* * *} \\
(0.108)\end{array}$ & $\begin{array}{c}-0.788^{* * *} \\
(0.189)\end{array}$ & $\begin{array}{c}-0.682^{* * *} \\
(0.147)\end{array}$ & $\begin{array}{c}-0.614^{* * *} \\
(0.157)\end{array}$ & $\begin{array}{c}-0.679 * * * \\
(0.136)\end{array}$ & $\begin{array}{c}-0.611^{* * *} \\
(0.206)\end{array}$ & $\begin{array}{c}-0.709^{* * *} \\
(0.158)\end{array}$ & $\begin{array}{c}0.013 \\
(0.336)\end{array}$ & $\begin{array}{l}-0.340 \\
(0.295)\end{array}$ & $\begin{array}{c}-0.859^{* * *} \\
(0.260)\end{array}$ & $\begin{array}{c}-0.660^{* * *} \\
(0.230)\end{array}$ \\
\hline Observations & 486 & 486 & 486 & 400 & 300 & 486 & 400 & 300 & 430 & 400 & 300 & 430 & 400 & 300 \\
\hline \multirow[t]{2}{*}{ Number of State-Age Goups } & 100 & 100 & 100 & 100 & 100 & 100 & 100 & 100 & 86 & 100 & 100 & 86 & 100 & 100 \\
\hline & \multicolumn{14}{|c|}{ Analsyis by MA and Year } \\
\hline$\%$ Manufacturing & $\begin{array}{c}-0.322^{* * *} \\
(0.052)\end{array}$ & $\begin{array}{c}-0.348^{* * *} \\
(0.068)\end{array}$ & $\begin{array}{c}-0.670^{* * *} \\
(0.099)\end{array}$ & $\begin{array}{c}-0.750^{* * *} \\
(0.094)\end{array}$ & $\begin{array}{c}-0.584^{* * *} \\
(0.143)\end{array}$ & $\begin{array}{c}-0.340^{* *} \\
(0.139)\end{array}$ & $\begin{array}{c}-0.541^{* * *} \\
(0.189)\end{array}$ & $\begin{array}{c}-0.688^{* * *} \\
(0.256)\end{array}$ & $\begin{array}{c}-0.961^{* * *} \\
(0.181)\end{array}$ & $\begin{array}{c}-0.848^{* * *} \\
(0.176)\end{array}$ & $\begin{array}{c}0.067 \\
(0.375)\end{array}$ & $\begin{array}{c}-1.703^{* *} \\
(0.752)\end{array}$ & $\begin{array}{c}-1.568^{* * *} \\
(0.438)\end{array}$ & $\begin{array}{c}-1.266^{*} \\
(0.711)\end{array}$ \\
\hline Observations & 590 & 590 & 590 & 471 & 353 & 590 & 471 & 353 & 590 & 471 & 351 & 590 & 471 & 351 \\
\hline Number of Metro Areas & 119 & 119 & 119 & 119 & 119 & 119 & 119 & 119 & 119 & 119 & 117 & 119 & 119 & 117 \\
\hline State or MA Time Trends & & & & & & Yes & Yes & Tes & & & & Yes & Yes & Yes \\
\hline
\end{tabular}


Table 7: Immigration and Manufacturing on Residual Inequality

\begin{tabular}{|c|c|c|c|c|c|c|c|c|c|}
\hline & \multicolumn{6}{|c|}{ OLS } & \multicolumn{3}{|c|}{ IV } \\
\hline & (1) & (2) & (3) & (4) & (5) & (6) & (7) & (8) & (9) \\
\hline Starting Year & 1970 & 1980 & 1990 & 1970 & 1980 & 1990 & 1970 & 1980 & 1990 \\
\hline & \multicolumn{9}{|c|}{ Analysis by State and Year } \\
\hline$\%$ Manufacturing & $\begin{array}{c}-0.971^{* * *} \\
(0.130)\end{array}$ & $\begin{array}{c}-0.933^{* * *} \\
(0.145)\end{array}$ & $\begin{array}{c}-0.916^{* * *} \\
(0.253)\end{array}$ & $\begin{array}{c}-0.850 * * * \\
(0.161)\end{array}$ & $\begin{array}{c}-0.741 * * * \\
(0.148)\end{array}$ & $\begin{array}{c}-0.749 * * * \\
(0.192)\end{array}$ & $\begin{array}{c}-0.780^{* *} \\
(0.350)\end{array}$ & $\begin{array}{c}-1.031^{* * *} \\
(0.275)\end{array}$ & $\begin{array}{c}-1.049 * * * \\
(0.369)\end{array}$ \\
\hline$\%$ Non-College Immigrants & $\begin{array}{c}0.228 \\
(0.179)\end{array}$ & $\begin{array}{c}0.064 \\
(0.209)\end{array}$ & $\begin{array}{c}-0.168 \\
(0.208)\end{array}$ & $\begin{array}{l}0.580^{* *} \\
(0.230)\end{array}$ & $\begin{array}{c}0.581^{* * *} \\
(0.163)\end{array}$ & $\begin{array}{c}0.234 \\
(0.208)\end{array}$ & $\begin{array}{c}0.330 \\
(0.334)\end{array}$ & $\begin{array}{c}0.511^{* * *} \\
(0.169)\end{array}$ & $\begin{array}{c}0.634^{* * * *} \\
(0.238)\end{array}$ \\
\hline$\%$ Manufacturing *\% Non-College Immigrants & & & & $\begin{array}{l}-2.533 \\
(1.626)\end{array}$ & $\begin{array}{c}-4.271^{* * * *} \\
(0.934)\end{array}$ & $\begin{array}{c}-4.068^{* * *} \\
(0.714)\end{array}$ & $\begin{array}{l}-1.917 \\
(3.394)\end{array}$ & $\begin{array}{l}-2.660^{*} \\
(1.466)\end{array}$ & $\begin{array}{c}-2.926 * * * \\
(1.033)\end{array}$ \\
\hline $\begin{array}{l}\text { Observations } \\
\text { Number of states }\end{array}$ & $\begin{array}{c}243 \\
50 \\
\end{array}$ & $\begin{array}{c}200 \\
50 \\
\end{array}$ & $\begin{array}{c}150 \\
50 \\
\end{array}$ & $\begin{array}{c}243 \\
50 \\
\end{array}$ & $\begin{array}{c}200 \\
50 \\
\end{array}$ & $\begin{array}{c}150 \\
50 \\
\end{array}$ & $\begin{array}{c}215 \\
43 \\
\end{array}$ & $\begin{array}{c}200 \\
50 \\
\end{array}$ & $\begin{array}{c}150 \\
50 \\
\end{array}$ \\
\hline Number of states & \multicolumn{9}{|c|}{ Analysis by State, Age-Group, and Year } \\
\hline$\%$ Manufacturing & $\begin{array}{c}-0.634^{* * *} \\
(0.110)\end{array}$ & $\begin{array}{c}-0.649 * * * \\
(0.123)\end{array}$ & $\begin{array}{c}-0.795^{* * *} \\
(0.189)\end{array}$ & $\begin{array}{c}-0.502 * * * \\
(0.118)\end{array}$ & $\begin{array}{c}-0.521 * * * \\
(0.114)\end{array}$ & $\begin{array}{c}-0.608^{* * *} \\
(0.145)\end{array}$ & $\begin{array}{c}-0.627^{* *} \\
(0.278)\end{array}$ & $\begin{array}{c}-0.861^{* * *} \\
(0.212)\end{array}$ & $\begin{array}{c}-0.718^{* *} \\
(0.341)\end{array}$ \\
\hline$\%$ Non-College Immigrants & $\begin{array}{c}0.114 \\
(0.189)\end{array}$ & $\begin{array}{l}-0.048 \\
(0.207)\end{array}$ & $\begin{array}{c}-0.168 \\
(0.169)\end{array}$ & $\begin{array}{c}0.627 * * * \\
(0.232)\end{array}$ & $\begin{array}{c}0.512^{* *} \\
(0.208)\end{array}$ & $\begin{array}{l}0.356^{*} \\
(0.184)\end{array}$ & $\begin{array}{l}0.538^{* *} \\
(0.233)\end{array}$ & $\begin{array}{l}0.591 * * \\
(0.230)\end{array}$ & $\begin{array}{c}0.659 * * * \\
(0.172)\end{array}$ \\
\hline$\%$ Manufacturing *\% Non-College Immigrants & & & & $\begin{array}{c}-3.782 * * * \\
(1.221)\end{array}$ & $\begin{array}{c}-4.391 * * * \\
(0.774)\end{array}$ & $\begin{array}{c}-3.925 * * * \\
(0.555)\end{array}$ & $\begin{array}{l}-3.210^{*} \\
(1.945)\end{array}$ & $\begin{array}{c}-3.103^{* * *} \\
(0.717)\end{array}$ & $\begin{array}{c}-3.410^{* * *} \\
(0.611)\end{array}$ \\
\hline \multirow[t]{2}{*}{ Number of states } & $\begin{array}{l}486 \\
100\end{array}$ & $\begin{array}{l}400 \\
100\end{array}$ & $\begin{array}{l}300 \\
100\end{array}$ & $\begin{array}{l}486 \\
100\end{array}$ & $\begin{array}{l}400 \\
100\end{array}$ & $\begin{array}{l}300 \\
100\end{array}$ & $\begin{array}{c}430 \\
86\end{array}$ & $\begin{array}{l}400 \\
100\end{array}$ & $\begin{array}{l}300 \\
100\end{array}$ \\
\hline & \multicolumn{9}{|c|}{ Analsyis by MA and Year } \\
\hline$\%$ Manufacturing & $\begin{array}{c}-0.671^{* * *} \\
(0.097)\end{array}$ & $\begin{array}{c}-0.745^{* * *} \\
(0.096)\end{array}$ & $\begin{array}{c}-0.580^{* * *} \\
(0.148)\end{array}$ & $\begin{array}{c}-0.589 * * * \\
(0.106)\end{array}$ & $\begin{array}{c}-0.572^{* * *} \\
(0.100)\end{array}$ & $\begin{array}{c}-0.370^{* * *} \\
(0.135)\end{array}$ & $\begin{array}{c}-1.062 * * * \\
(0.179)\end{array}$ & $\begin{array}{c}-0.852^{* * *} \\
(0.185)\end{array}$ & $\begin{array}{l}-0.201 \\
(0.291)\end{array}$ \\
\hline \% Non-College Immigrants & $\begin{array}{c}0.035 \\
(0.108)\end{array}$ & $\begin{array}{l}-0.082 \\
(0.130)\end{array}$ & $\begin{array}{l}-0.069 \\
(0.161)\end{array}$ & $\begin{array}{c}0.262 * * * \\
(0.083)\end{array}$ & $\begin{array}{c}0.195 * * \\
(0.086)\end{array}$ & $\begin{array}{l}0.262^{* *} \\
(0.122)\end{array}$ & $\begin{array}{l}0.350^{* *} \\
(0.154)\end{array}$ & $\begin{array}{c}0.133 \\
(0.130)\end{array}$ & $\begin{array}{c}0.494^{* * *} \\
(0.176)\end{array}$ \\
\hline$\%$ Manufacturing *\% Non-College Immigrants & & & & $\begin{array}{c}-1.796^{* *} \\
(0.848)\end{array}$ & $\begin{array}{c}-2.634^{* * * *} \\
(0.815)\end{array}$ & $\begin{array}{c}-3.050^{* * *} \\
(0.681)\end{array}$ & $\begin{array}{l}-2.050^{*} \\
(1.194)\end{array}$ & $\begin{array}{c}-1.644^{* *} \\
(0.736)\end{array}$ & $\begin{array}{c}-2.659 * * * \\
(0.602)\end{array}$ \\
\hline Observations & 590 & 471 & 353 & 590 & 471 & 353 & 590 & 471 & 351 \\
\hline Number of Metro Areas & 119 & 119 & 119 & 119 & 119 & 119 & 119 & 119 & 117 \\
\hline $\begin{array}{l}\text { Notes: Robust standard errors clustered by gec } \\
\text { for the } 5 \% \text { level, and * for the } 10 \% \text { level. Observ } \\
\text { for age, education, occupation, industry, with ur } \\
\text { controls for the geographic area's average wage } \\
\text { year and geographic area (state or metro area). } \\
\text { olds. The instrument for percent manufacturing } \\
\text { college immigrants is depicted by equation (2), } \\
\text { between percent manufacturing and percent no }\end{array}$ & $\begin{array}{l}\text { hic are } \\
\text { is are w } \\
\text { icted c } \\
\text { compo } \\
\text { ne state } \\
\text { " "shift- } \\
\text { now re } \\
\text { ege im }\end{array}$ & $\begin{array}{l}\text { or metr } \\
\text { ed by the } \\
\text { ents acro } \\
\text { and educ } \\
\text { age grour } \\
\text { " variable } \\
\text { to immi } \\
\text { ts is the }\end{array}$ & $\begin{array}{l}\text { described } \\
\text { cation distr } \\
\text { grants from } \\
\text { interaction }\end{array}$ & $\begin{array}{l}\text { ears are } \\
\text { (as indica } \\
\text { fects are } \\
\text { tion (2) in } \\
\text { y of origi } \\
\text { en the twe }\end{array}$ & $\begin{array}{l}\text { every ten ye } \\
\text { ated in colur } \\
\text { included fo } \\
n \text { the text. } \\
\text { in } \mathrm{j} \text { instead } \\
\text { o shift-shar }\end{array}$ & $\begin{array}{l}\text { ears from } \\
\mathrm{mn}(4) \text { of } \\
\text { r each ag } \\
\text { The "shift } \\
\text { of industr } \\
\text { e instrum }\end{array}$ & $\begin{array}{l}\text { ed by: }{ }^{* * *} \\
\text { ned as the } \\
\text { 10. All regr } \\
\text { as well as } \\
25-39 \text { year } \\
\text { strument } f \\
\text { hstrument }\end{array}$ & $\begin{array}{l}\text { for the 1\% } \\
90 / 10 \text { ratio } \\
\text { ressions incl } \\
\text { fixed-effects } \\
\text { olds and } 40 \\
\text { for the perce } \\
\text { for the inter }\end{array}$ & $\begin{array}{l}\text { level, }{ }^{* *} \\
\text { adjusted } \\
\text { lude } \\
\text { s for each } \\
\text { b-55 year } \\
\text { ent non- } \\
\text { raction }\end{array}$ \\
\hline
\end{tabular}


Table 8: Immigration and Manufacturing on Residual Inequality at the Upper Tail (90/50 Residual Ratio)

Starting Year

OLS
\begin{tabular}{ccccccc}
\hline 11$)$ & $(2)$ & $(3)$ & & $(4)$ & $(5)$ & $(6)$ \\
\cline { 1 - 2 } \cline { 5 - 7 } 1970 & 1970 & 1970 & & 1970 & 1980 & 1990
\end{tabular}

\begin{tabular}{ccc}
\multicolumn{3}{c}{ IV } \\
\hline$(7)$ & $(8)$ & $(9)$ \\
\hline 1970 & 1980 & 1990
\end{tabular}

$\%$ Manufacturing

$\%$ Non-College Immigrants

$\begin{array}{ccc}-0.281^{* * *} & -0.326^{* * *} & -0.257^{* *} \\ (0.068) & (0.076) & (0.100)\end{array}$

Analysis by State and Year

$\%$ Manufacturing *\% Non-College Immigrants

$\begin{array}{ccc}(0.068) & (0.076) & (0.100) \\ 0.119 & -0.002 & -0.035 \\ (0.103) & (0.138) & (0.136)\end{array}$

$-0.232 * * *-0.251 * * *-0.212 * *$

$\begin{array}{lll}(0.081) & (0.086) & (0.097)\end{array}$

$\begin{array}{ccc}-0.102 & -0.234 & -0.093 \\ (0.179) & (0.162) & (0.210)\end{array}$

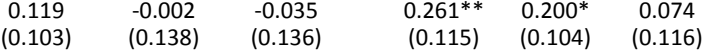

$\begin{array}{lll}-1.024 & -1.667^{*} & -1.108^{*}\end{array}$

(0.994) (0.833) (0.603)

$\begin{array}{ccc}0.165 & 0.069 & 0.213 \\ (0.161) & (0.118) & (0.137)\end{array}$

$\begin{array}{lll}-1.239 & -0.828 & -0.196\end{array}$

Observations

Number of states

\begin{tabular}{ccccccccc}
243 & 200 & 150 & 243 & 200 & 150 & 215 & 200 & 150 \\
50 & 50 & 50 & 50 & 50 & 50 & 43 & 50 & 50 \\
\hline
\end{tabular}

Analysis by State, Age-Group, and Year

$\%$ Manufacturing

$\%$ Non-College Immigrants

$\%$ Manufacturing *\% Non-College Immigrants

\begin{tabular}{ccc} 
& & \\
\cline { 3 - 3 } & & \\
$-0.155^{* * *}$ & $-0.160^{* *}$ & $-0.188^{*}$ \\
$(0.058)$ & $(0.072)$ & $(0.095)$ \\
0.059 & -0.073 & -0.090 \\
$(0.096)$ & $(0.117)$ & $(0.095)$
\end{tabular}

Observations

Number of states

\begin{tabular}{ccccccccc}
$-0.155^{* * *}$ & $-0.160^{* *}$ & $-0.188^{*}$ & -0.100 & -0.104 & -0.118 & -0.005 & -0.152 & -0.053 \\
$(0.058)$ & $(0.072)$ & $(0.095)$ & $(0.062)$ & $(0.071)$ & $(0.084)$ & $(0.134)$ & $(0.118)$ & $(0.180)$ \\
0.059 & -0.073 & -0.090 & $0.273^{* * *}$ & $0.171^{*}$ & 0.105 & $0.207^{*}$ & 0.172 & $0.273^{* *}$ \\
$(0.096)$ & $(0.117)$ & $(0.095)$ & $(0.094)$ & $(0.100)$ & $(0.097)$ & $(0.115)$ & $(0.130)$ & $(0.126)$ \\
& & & $-1.581^{* *}$ & $-1.913^{* * *}$ & $-1.461^{* * *}$ & -1.600 & $-1.228^{* *}$ & $-1.167^{* * *}$ \\
& & & $(0.638)$ & $(0.503)$ & $(0.334)$ & $(0.986)$ & $(0.487)$ & $(0.337)$ \\
& & & & & & & & \\
486 & 400 & 300 & 486 & 400 & 300 & 430 & 400 & 300 \\
100 & 100 & 100 & 100 & 100 & 100 & 86 & 100 & 100 \\
\hline
\end{tabular}

\% Manufacturing

$\%$ Non-College Immigrants

$\%$ Manufacturing *\% Non-College Immigrants

Analsyis by MA and Year

\begin{tabular}{|c|c|c|c|c|c|c|c|c|}
\hline$-0.324^{* * *}$ & $-0.371^{* * *}$ & $-0.335^{* * *}$ & $-0.313^{* * *}$ & $-0.329 * * *$ & $-0.298 * * *$ & $-0.374^{* * *}$ & $-0.390 * * *$ & -0.238 \\
\hline$(0.047)$ & $(0.056)$ & $(0.090)$ & $(0.048)$ & $(0.053)$ & $(0.088)$ & $(0.086)$ & $(0.113)$ & $(0.147)$ \\
\hline 0.068 & -0.009 & 0.030 & $0.098^{*}$ & 0.058 & 0.089 & 0.057 & 0.023 & 0.137 \\
\hline \multirow[t]{3}{*}{$(0.057)$} & $(0.071)$ & $(0.076)$ & $(0.057)$ & $(0.067)$ & $(0.091)$ & (0.068) & $(0.071)$ & $(0.144)$ \\
\hline & & & -0.237 & $-0.645 *$ & -0.535 & 0.029 & -0.163 & -0.243 \\
\hline & & & $(0.311)$ & $(0.357)$ & $(0.360)$ & $(0.479)$ & $(0.309)$ & $(0.315)$ \\
\hline
\end{tabular}

Observations

$590 \quad 471 \quad 353$

$\begin{array}{lll}(0.479) & (0.309) \quad(0.315)\end{array}$

$119 \quad 119 \quad 119$

$590 \quad 471 \quad 353$

$\begin{array}{lll}590 & 471 & 351\end{array}$

Notes: Robust standard errors clustered by geographic area (state or metro area) are in parentheses. Significance levels are indicated by: $*^{* * *}$ for the $1 \%$ level, ${ }^{* *}$

for the $5 \%$ level, and * for the $10 \%$ level. Observations are weighted by the local population size in 1990 . "Residual Inequality" is defined as the $90 / 10$ ratio adjusted for age, education, occupation, industry, with unrestricted coefficients across years. Sample years are every ten years from 1970-2010. All regressions include

controls for the geographic area's average wage, age composition, and education distribution (as indicated in column (4) of Table 4), as well as fixed-effects for each

year and geographic area (state or metro area). For the state-year-age group analysis, fixed-effects are included for each age group: 25-39 year olds and 40-55 year olds. The instruments for the percent manufacturing, percent non-college immigrants, and the interaction between the two are described in the notes to Table 7. 
Table 9: Immigration and Manufacturing on Residual Inequality at the Lower Tail (50/10 Residual Ratio)

Starting Year

\begin{tabular}{|c|c|c|c|c|c|}
\hline \multicolumn{6}{|c|}{ OLS } \\
\hline (1) & (2) & (3) & (4) & (5) & (6) \\
\hline 1970 & 1970 & 1970 & 1970 & 1980 & 1990 \\
\hline
\end{tabular}

\begin{tabular}{ccc}
\multicolumn{3}{c}{ IV } \\
\hline$(7)$ & $(8)$ & $(9)$ \\
\hline 1970 & 1980 & 1990
\end{tabular}

\% Manufacturing

$\%$ Non-College Immigrants

$\begin{array}{cccccc}-0.690^{* * *} & -0.607^{* * *} & -0.659^{* * *} & -0.617^{* * *} & -0.490^{* * *} & -0.537^{* * *} \\ (0.083) & (0.103) & (0.197) & (0.099) & (0.094) & (0.146) \\ 0.109 & 0.066 & -0.133 & 0.318^{* *} & 0.381^{* * *} & 0.160 \\ (0.100) & (0.101) & (0.147) & (0.155) & (0.130) & (0.172) \\ & & & -1.510^{*} & -2.604^{* * *} & -2.960^{* * *} \\ & & & (0.759) & (0.552) & (0.769)\end{array}$

$-0.678^{* * *}-0.797 * * *-0.956 * * *$

$\begin{array}{lll}(0.200) & (0.145) & (0.266)\end{array}$

$\begin{array}{lll}0.165 & 0.442^{* * *} & 0.421^{* *}\end{array}$

$\begin{array}{lll}(0.223) & (0.141) \quad(0.179)\end{array}$

$-0.678-1.832 * * *-2.730 * * *$

$\begin{array}{lll}(1.765) & (0.636) & (0.731)\end{array}$

$\%$ Manufacturing *\% Non-College Immigrant

Observations

Number of states

$\begin{array}{cccccc}243 & 200 & 150 & 243 & 200 & 150 \\ 50 & 50 & 50 & 50 & 50 & 50\end{array}$

$\begin{array}{ccc}215 & 200 & 150 \\ 43 & 50 & 50\end{array}$

Analysis by State, Age-Group, and Year

\% Manufacturing

$\%$ Non-College Immigrants

$\%$ Manufacturing *\% Non-College Immigrants

$\begin{array}{ccc}-0.479 * * * & -0.489 * * * & -0.607 * * * \\ (0.072) & (0.078) & (0.144) \\ 0.055 & 0.025 & -0.078 \\ (0.112) & (0.125) & (0.142)\end{array}$

$-0.403^{* * *}-0.417^{* * *}-0.490^{* * *}$

$\begin{array}{lll}(0.074) & (0.071) \quad(0.117)\end{array}$

$\begin{array}{lll}0.354^{* *} & 0.341^{* *} & 0.251\end{array}$

$\begin{array}{lll}(0.163) & (0.149) & (0.159)\end{array}$

$-2.201^{* * *}-2.478^{* * *}-2.464^{* * *}$

$-0.623 * * *-0.709 * * *-0.665 * * *$

$\begin{array}{lll}(0.177) \quad(0.127) \quad(0.237) & 0.00\end{array}$

$\begin{array}{lll}(0.112) & (0.125) \quad(0.142)\end{array}$

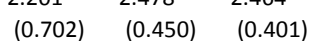

$(0.157) \quad(0.142) \quad(0.151)$

$-1.609-1.874 * * *-2.243 * * *$

$\begin{array}{lll}(1.062) & (0.355) & (0.353)\end{array}$

Observations

Number of states

\begin{tabular}{|c|c|c|c|c|c|c|c|c|}
\hline 486 & 400 & 300 & 486 & 400 & 300 & 430 & 400 & 300 \\
\hline 100 & 100 & 100 & 100 & & & & & \\
\hline
\end{tabular}

$\%$ Manufacturing

$\%$ Non-College Immigrants

Analsyis by MA and Year

$\%$ Manufacturing *\% Non-College Immigrants

\begin{tabular}{ccccccccc}
$-0.347^{* * *}$ & $-0.373^{* * *}$ & $-0.244^{* *}$ & $-0.276^{* * *}$ & $-0.243^{* * *}$ & -0.071 & $-0.688^{* * *}$ & $-0.462^{* * *}$ & 0.037 \\
$(0.069)$ & $(0.069)$ & $(0.097)$ & $(0.077)$ & $(0.077)$ & $(0.084)$ & $(0.145)$ & $(0.123)$ & $(0.223)$ \\
-0.032 & -0.073 & -0.099 & $0.164^{* *}$ & $0.136^{* *}$ & $0.174^{*}$ & $0.293^{* *}$ & 0.110 & $0.356^{* * *}$ \\
$(0.070)$ & $(0.087)$ & $(0.135)$ & $(0.068)$ & $(0.066)$ & $(0.102)$ & $(0.133)$ & $(0.093)$ & $(0.120)$ \\
& & \multicolumn{9}{c}{$-1.559^{* * *}$} & $-1.990^{* * *}$ & $-2.515^{* * *}$ & $-2.079^{* * *}$ & $-1.481^{* * *}$ & $-2.416^{* * *}$ \\
& & & $0.594)$ & $(0.515)$ & $(0.470)$ & $(0.781)$ & $(0.495)$ & $(0.462)$
\end{tabular}

Observations

$590 \quad 471 \quad 353$

$(0.781) \quad(0.495) \quad(0.462)$

tro Areas

$119 \quad \begin{array}{llll}119 & 590 & 471 & 353\end{array}$

$590 \quad 471 \quad 351$

Notes: Robust standard errors clustered by geographic area (state or metro area) are in parentheses. Significance levels are indicated by: *** for the $1 \%$ level, ${ }^{* *}$

for the $5 \%$ level, and * for the $10 \%$ level. Observations are weighted by the local population size in 1990 . "Residual Inequality" is defined as the $90 / 10$ ratio adjusted for age, education, occupation, industry, with unrestricted coefficients across years. Sample years are every ten years from 1970-2010. All regressions include

controls for the geographic area's average wage, age composition, and education distribution (as indicated in column (4) of Table 4), as well as fixed-effects for each

year and geographic area (state or metro area). For the state-year-age group analysis, fixed-effects are included for each age group: 25-39 year olds and 40-55 year olds. The instruments for the percent manufacturing, percent non-college immigrants, and the interaction between the two are described in the notes to Table 7. 
Table 10: Immigration and Manufacturing on Non-College Graduate Employment Rates

\begin{tabular}{|c|c|c|c|c|c|c|c|c|c|c|c|c|}
\hline & \multicolumn{6}{|c|}{ OLS } & \multicolumn{6}{|c|}{ IV } \\
\hline & (1) & (2) & (3) & (4) & (5) & (6) & (7) & (8) & (9) & (10) & (11) & (12) \\
\hline Starting Year & 1970 & 1970 & 1970 & 1970 & 1980 & 1990 & 1970 & 1980 & 1990 & 1970 & 1980 & 1990 \\
\hline & \multicolumn{12}{|c|}{ Analysis by State and Year } \\
\hline$\%$ Manufacturing & $\begin{array}{c}0.239 * * * \\
(0.045)\end{array}$ & $\begin{array}{c}0.268^{* * *} \\
(0.057)\end{array}$ & $\begin{array}{c}0.529 * * * \\
(0.131)\end{array}$ & $\begin{array}{c}0.151^{* * *} \\
(0.044)\end{array}$ & $\begin{array}{c}0.187^{* * *} \\
(0.056)\end{array}$ & $\begin{array}{c}0.447^{* * *} \\
(0.114)\end{array}$ & $\begin{array}{c}0.100 \\
(0.076)\end{array}$ & $\begin{array}{c}0.043 \\
(0.092)\end{array}$ & $\begin{array}{c}0.023 \\
(0.225)\end{array}$ & $\begin{array}{c}0.068 \\
(0.066)\end{array}$ & $\begin{array}{l}-0.011 \\
(0.085)\end{array}$ & $\begin{array}{l}0.389^{*} \\
(0.225)\end{array}$ \\
\hline$\%$ Non-College Immigrants & $\begin{array}{c}-0.193^{* * *} \\
(0.041)\end{array}$ & $\begin{array}{c}-0.396 * * * \\
(0.051)\end{array}$ & $\begin{array}{c}-0.554^{* * *} \\
(0.180)\end{array}$ & $\begin{array}{c}-0.448^{* * *} \\
(0.069)\end{array}$ & $\begin{array}{c}-0.612^{* * *} \\
(0.071)\end{array}$ & $\begin{array}{c}-0.752^{* * *} \\
(0.172)\end{array}$ & $\begin{array}{c}-0.204^{* * *} \\
(0.051)\end{array}$ & $\begin{array}{c}-0.443^{* * *} \\
(0.092)\end{array}$ & $\begin{array}{c}-0.831^{* * *} \\
(0.322)\end{array}$ & $\begin{array}{c}-0.510^{* * *} \\
(0.088)\end{array}$ & $\begin{array}{c}-0.676 * * * \\
(0.096)\end{array}$ & $\begin{array}{c}-0.660^{* * *} \\
(0.166)\end{array}$ \\
\hline$\%$ Manufacturing *\% Non-College Immigrants & & & & $\begin{array}{c}1.837^{* * *} \\
(0.585)\end{array}$ & $\begin{array}{c}1.791^{* * *} \\
(0.654)\end{array}$ & $\begin{array}{c}1.998 * * * \\
(0.690)\end{array}$ & & & & $\begin{array}{c}2.203^{* * *} \\
(0.539)\end{array}$ & $\begin{array}{c}2.696^{* * * *} \\
(0.860)\end{array}$ & $\begin{array}{c}2.702^{* * *} \\
(0.821)\end{array}$ \\
\hline Observations & 243 & 200 & 150 & 243 & 200 & 150 & 215 & 200 & 150 & 215 & 200 & 150 \\
\hline \multirow[t]{2}{*}{ Number of states } & 50 & 50 & 50 & 50 & 50 & 50 & 43 & 50 & 50 & 43 & 50 & 50 \\
\hline & \multicolumn{12}{|c|}{ Analysis by State, Age-Group, and Year } \\
\hline$\%$ Manufacturing & $\begin{array}{c}0.176 * * * \\
(0.033)\end{array}$ & $\begin{array}{c}0.239 * * * \\
(0.045)\end{array}$ & $\begin{array}{c}0.417^{* * *} \\
(0.090)\end{array}$ & $\begin{array}{c}0.117^{* * *} \\
(0.032)\end{array}$ & $\begin{array}{c}0.192^{* * *} \\
(0.043)\end{array}$ & $\begin{array}{c}0.332^{* * *} \\
(0.075)\end{array}$ & $\begin{array}{l}0.128^{* *} \\
(0.063)\end{array}$ & $\begin{array}{c}0.050 \\
(0.073)\end{array}$ & $\begin{array}{l}-0.091 \\
(0.190)\end{array}$ & $\begin{array}{l}0.100^{*} \\
(0.057)\end{array}$ & $\begin{array}{c}0.028 \\
(0.068)\end{array}$ & $\begin{array}{c}0.141 \\
(0.200)\end{array}$ \\
\hline$\%$ Non-College Immigrants & $\begin{array}{c}-0.161^{* * *} \\
(0.047)\end{array}$ & $\begin{array}{c}-0.344 * * * \\
(0.069)\end{array}$ & $\begin{array}{c}-0.360^{* * *} \\
(0.130)\end{array}$ & $\begin{array}{c}-0.391^{* * *} \\
(0.050)\end{array}$ & $\begin{array}{c}-0.550^{* * *} \\
(0.059)\end{array}$ & $\begin{array}{c}-0.597^{* * *} \\
(0.112)\end{array}$ & $\begin{array}{c}-0.197^{* * *} \\
(0.045)\end{array}$ & $\begin{array}{c}-0.408^{* * *} \\
(0.074)\end{array}$ & $\begin{array}{c}-0.614^{* * *} \\
(0.173)\end{array}$ & $\begin{array}{c}-0.426^{* * *} \\
(0.051)\end{array}$ & $\begin{array}{c}-0.525 * * * \\
(0.067)\end{array}$ & $\begin{array}{c}-0.538^{* * *} \\
(0.138)\end{array}$ \\
\hline$\%$ Manufacturing *\% Non-College Immigrants & & & & $\begin{array}{c}1.695^{* * *} \\
(0.311)\end{array}$ & $\begin{array}{c}1.621^{* * *} \\
(0.364)\end{array}$ & $\begin{array}{c}1.779 * * * \\
(0.392)\end{array}$ & & & & $\begin{array}{c}1.877 * * * \\
(0.361)\end{array}$ & $\begin{array}{c}1.837^{* * * *} \\
(0.533)\end{array}$ & $\begin{array}{c}1.874^{* * *} \\
(0.519)\end{array}$ \\
\hline Observations & 486 & 400 & 300 & 486 & 400 & 300 & 430 & 400 & 300 & 430 & 400 & 300 \\
\hline Number of states & 100 & 100 & 100 & 100 & 100 & 100 & 86 & 100 & 100 & 86 & 100 & 100 \\
\hline & \multicolumn{12}{|c|}{ Analsyis by MA and Year } \\
\hline$\%$ Manufacturing & $\begin{array}{c}0.180 * * * \\
(0.045)\end{array}$ & $\begin{array}{c}0.208^{* * *} \\
(0.053)\end{array}$ & $\begin{array}{c}0.364^{* * *} \\
(0.079)\end{array}$ & $\begin{array}{c}0.142^{* * *} \\
(0.046)\end{array}$ & $\begin{array}{c}0.178 * * * \\
(0.059)\end{array}$ & $\begin{array}{c}0.331^{* * *} \\
(0.085)\end{array}$ & $\begin{array}{c}0.094 \\
(0.068)\end{array}$ & $\begin{array}{c}0.070 \\
(0.087)\end{array}$ & $\begin{array}{l}0.256^{*} \\
(0.136)\end{array}$ & $\begin{array}{l}0.136 * \\
(0.075)\end{array}$ & $\begin{array}{c}0.057 \\
(0.089)\end{array}$ & $\begin{array}{c}0.259 * * \\
(0.121)\end{array}$ \\
\hline$\%$ Non-College Immigrants & $\begin{array}{c}-0.080^{* *} \\
(0.033)\end{array}$ & $\begin{array}{c}-0.218^{* * *} \\
(0.034)\end{array}$ & $\begin{array}{c}-0.261^{* * *} \\
(0.064)\end{array}$ & $\begin{array}{c}-0.184^{* * *} \\
(0.033)\end{array}$ & $\begin{array}{c}-0.266^{* * *} \\
(0.039)\end{array}$ & $\begin{array}{c}-0.314 * * * \\
(0.067)\end{array}$ & $\begin{array}{c}-0.129 * * * \\
(0.034)\end{array}$ & $\begin{array}{c}-0.295^{* * *} \\
(0.043)\end{array}$ & $\begin{array}{c}-0.408^{* * *} \\
(0.074)\end{array}$ & $\begin{array}{c}-0.262^{* * *} \\
(0.042)\end{array}$ & $\begin{array}{c}-0.317^{* * *} \\
(0.049)\end{array}$ & $\begin{array}{c}-0.379 * * * \\
(0.070)\end{array}$ \\
\hline$\%$ Manufacturing *\% Non-College Immigrants & & & & $\begin{array}{c}0.821 * * * \\
(0.178)\end{array}$ & $\begin{array}{c}0.456^{* *} \\
(0.194)\end{array}$ & $\begin{array}{l}0.482^{*} \\
(0.289)\end{array}$ & & & & $\begin{array}{c}1.284^{* * *} \\
(0.274)\end{array}$ & $\begin{array}{c}0.855^{* * *} \\
(0.247)\end{array}$ & $\begin{array}{c}0.505 \\
(0.324)\end{array}$ \\
\hline Observations & 590 & 471 & 353 & 590 & 471 & 353 & 590 & 471 & 351 & 590 & 471 & 351 \\
\hline Number of Metro Areas & 119 & 119 & 119 & 119 & 119 & 119 & 119 & 119 & 117 & 119 & 119 & 117 \\
\hline
\end{tabular}


Table 11: Immigration and Manufacturing on the Return to College

\begin{tabular}{|c|c|c|c|c|c|c|c|c|c|c|c|c|}
\hline & \multicolumn{6}{|c|}{ OLS } & \multicolumn{6}{|c|}{ IV } \\
\hline & (1) & (2) & (3) & (4) & (5) & (6) & (7) & (8) & (9) & (10) & (11) & (12) \\
\hline Starting Year & 1970 & 1970 & 1970 & 1970 & 1980 & 1990 & 1970 & 1980 & 1990 & 1970 & 1980 & 1990 \\
\hline & \multicolumn{12}{|c|}{ Analysis by State and Year } \\
\hline$\%$ Manufacturing & $\begin{array}{l}-0.280^{*} \\
(0.150)\end{array}$ & $\begin{array}{c}-0.510^{* * *} \\
(0.146)\end{array}$ & $\begin{array}{c}-0.887^{* * *} \\
(0.220)\end{array}$ & $\begin{array}{l}-0.231 \\
(0.156)\end{array}$ & $\begin{array}{c}-0.463^{* * *} \\
(0.148)\end{array}$ & $\begin{array}{c}-0.846 * * * \\
(0.217)\end{array}$ & $\begin{array}{l}-0.263 \\
(0.294)\end{array}$ & $\begin{array}{c}-0.951^{* * *} \\
(0.223)\end{array}$ & $\begin{array}{c}-1.888^{* * *} \\
(0.406)\end{array}$ & $\begin{array}{l}-0.232 \\
(0.285)\end{array}$ & $\begin{array}{c}-0.934^{* * *} \\
(0.228)\end{array}$ & $\begin{array}{c}-1.899 * * * \\
(0.368)\end{array}$ \\
\hline \% Non-College Immigrants & $\begin{array}{c}0.702^{* * *} \\
(0.135)\end{array}$ & $\begin{array}{c}0.549^{* * *} \\
(0.154)\end{array}$ & $\begin{array}{c}0.099 \\
(0.202)\end{array}$ & $\begin{array}{c}0.843^{* * *} \\
(0.152)\end{array}$ & $\begin{array}{c}0.675^{* * *} \\
(0.170)\end{array}$ & $\begin{array}{c}0.197 \\
(0.239)\end{array}$ & $\begin{array}{c}0.697^{* * *} \\
(0.187)\end{array}$ & $\begin{array}{c}0.709 * * * \\
(0.201)\end{array}$ & $\begin{array}{l}0.497^{* *} \\
(0.217)\end{array}$ & $\begin{array}{c}0.992^{* * *} \\
(0.179)\end{array}$ & $\begin{array}{c}0.780^{* * *} \\
(0.190)\end{array}$ & $\begin{array}{c}0.492^{* * *} \\
(0.186)\end{array}$ \\
\hline$\%$ Manufacturing *\% Non-College Immigrants & & & & $\begin{array}{l}-1.017 \\
(1.210)\end{array}$ & $\begin{array}{l}-1.039 \\
(1.170)\end{array}$ & $\begin{array}{c}-0.992 \\
(0.950)\end{array}$ & & & & $\begin{array}{l}-2.125^{*} \\
(1.143)\end{array}$ & $\begin{array}{l}-0.825 \\
(1.179)\end{array}$ & $\begin{array}{l}-0.077 \\
(0.886)\end{array}$ \\
\hline Observations & 243 & 200 & 150 & 243 & 200 & 150 & 215 & 200 & 150 & 215 & 200 & 150 \\
\hline \multirow[t]{2}{*}{ Number of states } & 50 & 50 & 50 & 50 & 50 & 50 & 43 & 50 & 50 & 43 & 50 & 50 \\
\hline & \multicolumn{12}{|c|}{ Analysis by State, Age-Group, and Year } \\
\hline$\%$ Manufacturing & $\begin{array}{l}-0.157 \\
(0.124)\end{array}$ & $\begin{array}{c}-0.345^{* * *} \\
(0.114)\end{array}$ & $\begin{array}{c}-0.599 * * * \\
(0.153)\end{array}$ & $\begin{array}{l}-0.159 \\
(0.131)\end{array}$ & $\begin{array}{c}-0.342^{* * *} \\
(0.117)\end{array}$ & $\begin{array}{c}-0.574^{* * *} \\
(0.157)\end{array}$ & $\begin{array}{l}-0.155 \\
(0.272)\end{array}$ & $\begin{array}{c}-0.572 * * * \\
(0.202)\end{array}$ & $\begin{array}{l}-0.535 \\
(0.400)\end{array}$ & $\begin{array}{l}-0.136 \\
(0.276)\end{array}$ & $\begin{array}{c}-0.568 * * * \\
(0.202)\end{array}$ & $\begin{array}{l}-0.619 \\
(0.424)\end{array}$ \\
\hline$\%$ Non-College Immigrants & $\begin{array}{c}0.518^{* * *} \\
(0.121)\end{array}$ & $\begin{array}{c}0.413 * * * \\
(0.120)\end{array}$ & $\begin{array}{c}0.130 \\
(0.137)\end{array}$ & $\begin{array}{c}0.508^{* * *} \\
(0.111)\end{array}$ & $\begin{array}{c}0.430 * * * \\
(0.136)\end{array}$ & $\begin{array}{c}0.199 \\
(0.194)\end{array}$ & $\begin{array}{c}0.527^{* * *} \\
(0.182)\end{array}$ & $\begin{array}{c}0.613 * * * \\
(0.180)\end{array}$ & $\begin{array}{l}0.585^{*} \\
(0.338)\end{array}$ & $\begin{array}{c}0.679 * * * \\
(0.162)\end{array}$ & $\begin{array}{c}0.634 * * * \\
(0.196)\end{array}$ & $\begin{array}{l}0.558^{* *} \\
(0.272)\end{array}$ \\
\hline$\%$ Manufacturing $* \%$ Non-College Immigrants & & & & $\begin{array}{c}0.076 \\
(0.938)\end{array}$ & $\begin{array}{l}-0.129 \\
(0.721)\end{array}$ & $\begin{array}{l}-0.516 \\
(0.659)\end{array}$ & & & & $\begin{array}{l}-1.250 \\
(1.117)\end{array}$ & $\begin{array}{l}-0.325 \\
(0.780)\end{array}$ & $\begin{array}{l}-0.681 \\
(1.046)\end{array}$ \\
\hline Observations & 486 & 400 & 300 & 486 & 400 & 300 & 430 & 400 & 300 & 430 & 400 & 300 \\
\hline Number of states & 100 & 100 & 100 & 100 & 100 & 100 & 86 & 100 & 100 & 86 & 100 & 100 \\
\hline & \multicolumn{12}{|c|}{ Analsyis by MA and Year } \\
\hline \% Manufacturing & $\begin{array}{l}-0.066 \\
(0.105)\end{array}$ & $\begin{array}{c}-0.256^{* *} \\
(0.099)\end{array}$ & $\begin{array}{c}-0.476 * * * \\
(0.156)\end{array}$ & $\begin{array}{l}-0.122 \\
(0.111)\end{array}$ & $\begin{array}{c}-0.331^{* * *} \\
(0.098)\end{array}$ & $\begin{array}{c}-0.503 * * * \\
(0.167)\end{array}$ & $\begin{array}{l}-0.217 \\
(0.241)\end{array}$ & $\begin{array}{c}-0.671 * * * \\
(0.207)\end{array}$ & $\begin{array}{c}-0.556^{* *} \\
(0.280)\end{array}$ & $\begin{array}{l}-0.252 \\
(0.260)\end{array}$ & $\begin{array}{c}-0.667^{* * *} \\
(0.209)\end{array}$ & $\begin{array}{c}-0.556 * * \\
(0.281)\end{array}$ \\
\hline$\%$ Non-College Immigrants & $\begin{array}{c}0.191 \\
(0.124)\end{array}$ & $\begin{array}{c}0.135 \\
(0.114)\end{array}$ & $\begin{array}{l}-0.071 \\
(0.130)\end{array}$ & $\begin{array}{c}0.034 \\
(0.098)\end{array}$ & $\begin{array}{c}0.015 \\
(0.093)\end{array}$ & $\begin{array}{l}-0.115 \\
(0.129)\end{array}$ & $\begin{array}{l}0.362^{*} \\
(0.209)\end{array}$ & $\begin{array}{c}0.140 \\
(0.226)\end{array}$ & $\begin{array}{c}0.126 \\
(0.167)\end{array}$ & $\begin{array}{c}0.470 \\
(0.286)\end{array}$ & $\begin{array}{c}0.147 \\
(0.250)\end{array}$ & $\begin{array}{c}0.119 \\
(0.142)\end{array}$ \\
\hline$\%$ Manufacturing *\% Non-College Immigrants & & & & $\begin{array}{l}1.243^{*} \\
(0.681)\end{array}$ & $\begin{array}{c}1.143^{* * *} \\
(0.431)\end{array}$ & $\begin{array}{c}0.401 \\
(0.495)\end{array}$ & & & & $\begin{array}{l}-1.031 \\
(1.585)\end{array}$ & $\begin{array}{l}-0.254 \\
(1.029)\end{array}$ & $\begin{array}{l}-0.111 \\
(0.866)\end{array}$ \\
\hline Observations & 590 & 471 & 353 & 590 & 471 & 353 & 590 & 471 & 351 & 590 & 471 & 351 \\
\hline Number of Metro Areas & 119 & 119 & 119 & 119 & 119 & 119 & 119 & 119 & 117 & 119 & 119 & 117 \\
\hline
\end{tabular}


OLS

\begin{tabular}{cccc}
\hline $\begin{array}{c}\Delta \text { Residual } \\
90 / 10\end{array}$ & $\begin{array}{c}\Delta \text { Residual } \\
90 / 50\end{array}$ & $\begin{array}{c}\Delta \text { Residual } \\
50 / 10\end{array}$ & $\begin{array}{c}\Delta \text { Non-College } \\
\text { Employment } \\
\text { Rate }\end{array}$ \\
& & & \\
\hline
\end{tabular}

(1) (2) (3) $\quad$ (4)

Annual $\Delta \%$ Manufacturing

(Autor, Dorn, and Hanson (2013))

$\Delta \%$ Non-College Immigrants

$\begin{array}{cccc}-0.005^{* * *} & -0.002^{* *} & -0.003^{* * *} & 0.004^{* * *} \\ (0.001) & (0.001) & (0.001) & (0.001) \\ & & & \\ & & & \\ 0.285^{*} & 0.067 & 0.218^{*} & -0.246^{* * *} \\ (0.153) & (0.060) & (0.111) & (0.057)\end{array}$

$\Delta \%$ Manufacturing

$\Delta \%$ Non-College Immigrants

Number of Observations

Number of Commuting Zones

\begin{tabular}{cccc}
$-0.551^{* * *}$ & $-0.226^{* * *}$ & $-0.325^{* * *}$ & $0.305^{* * *}$ \\
$(0.095)$ & $(0.055)$ & $(0.058)$ & $(0.046)$ \\
& & & \\
$0.273^{*}$ & 0.058 & $0.215^{*}$ & $-0.263^{* * *}$ \\
$(0.150)$ & $(0.059)$ & $(0.110)$ & $(0.058)$ \\
\hline & & & \\
1,444 & 1,444 & 1,444 & 1,444 \\
722 & 722 & 722 & 722
\end{tabular}

IV

"China Syndrome" IV for $\triangle$ MFG

"Shift Share" IV for $\Delta$ Non-College Immigrant Share

\begin{tabular}{cccc}
\hline $\begin{array}{c}\Delta \text { Residual } \\
90 / 10\end{array}$ & $\begin{array}{c}\Delta \text { Residual } \\
90 / 50\end{array}$ & $\begin{array}{c}\Delta \text { Residual } \\
50 / 10\end{array}$ & $\begin{array}{c}\Delta \text { Non-College } \\
\text { Employment } \\
\text { Rate }\end{array}$ \\
\hline$(5)$ & $(6)$ & $(7)$ & $(8)$ \\
-0.002 & 0.001 & $-0.003^{*}$ & $0.007^{* * *}$ \\
$(0.003)$ & $(0.002)$ & $(0.002)$ & $(0.001)$ \\
& & & \\
$0.759 * * *$ & $0.177^{* *}$ & $0.582^{* * *}$ & $-0.338^{* * *}$ \\
$(0.226)$ & $(0.079)$ & $(0.158)$ & $(0.094)$ \\
& & & \\
\hline & & & \\
-0.193 & 0.079 & $-0.273^{*}$ & $0.574^{* * *}$ \\
$(0.215)$ & $(0.153)$ & $(0.140)$ & $(0.092)$ \\
$0.766^{* * *}$ & $0.174^{* *}$ & $0.592^{* * *}$ & $-0.357^{* * *}$ \\
$(0.218)$ & $(0.078)$ & $(0.149)$ & $(0.117)$ \\
\hline 1,444 & 1,444 & 1,444 & 1,444 \\
722 & 722 & 722 & 722 \\
\hline
\end{tabular}

Notes: Each observation refers to the difference between 1990-2000 or 2000-2010 within a commuting zone (CZ) in the indicated measure. The "China Syndrome" instrument represents the local exposure to Chinese imports from Autor, Dorn, and Hanson (2013). (The variable in their data release is called "d_tradeotch_pw_lag"). The annual local change in the share of male workers in manufacturing is called "d_sh_empl_mfg_m" in the data release from Autor, Dorn, and Hanson (2013). Robust standard errors clustered by state are in parentheses. Significance levels are indicated by: $* * *$ for the $1 \%$ level, $* *$ for the $5 \%$ level, and $*$ for the $10 \%$ level. Observations are weighted by the local population size in 1990 from Autor, Dorn, and Hanson (2013) (called "timepwt48" in their data release). Each observation represents the ten year difference between years 1990-2000 or 2000-2010 (except when the change is annualized). All regressions include the ten-year differences in control variables for the geographic area's average wage, age composition, and education distribution (as indicated in column (4) of Table 4), as well as fixed-effects for each year. The instruments for the percent manufacturing and the percent non-college immigrants are described in the heading of the right panel. The instrument for the interaction term is the interaction between the two instruments for the percent manufacturing and the percent non-college immigrants. 
Table 13: Categorizing States According to the Size of the Shift in Manufacturing and Immigration (1980-2010)

$\triangle$ MFG Low

$\Delta$ Immigration Low

Alaska
Arkansas
Hawaii
lowa
Kentucky
Louisiana
Minnesota
Mississippi
Montana
North Dakota
South Dakota
Wisconsin
Wyoming

$\triangle$ MFG Low

$\Delta$ Immigration High

Arizona
Colorado
Florida
Idaho
Kansas
Nebraska
Nevada
New Mexico
Oklahoma
Texas
Utah
Virginia

$\triangle$ MFG High

$\Delta$ Immigration Low

$\Delta$ Immigration Low

$\triangle$ MFG High

$\Delta$ Immigration High

States are divided into one of four categories according to whether they were above or below the median in terms of the decline in the state's manufacturing employment share and the increase in the state's share of non-college immigrants from 1980-2010. The four categories are: (1) above the median for both shocks (decline in manufacturing and increase in non-college immigration); (2) above the median for manufacturing but below the median for immigration; ( 3 ) below the

median for manufacturing but above the median for immigration; and (4) below the median for both.
Alabama
Indiana
Maine
Michigan
Missouri
New Hampshire
Ohio
Pennsylvania
South Carolina
Tennessee
Vermont
West Virginia

California

Connecticut

Delaware

Georgia

Illinois

Maryland

Massachusetts

New Jersey

New York

North Carolina

Oregon

Rhode Island

Washington 
Figure 1

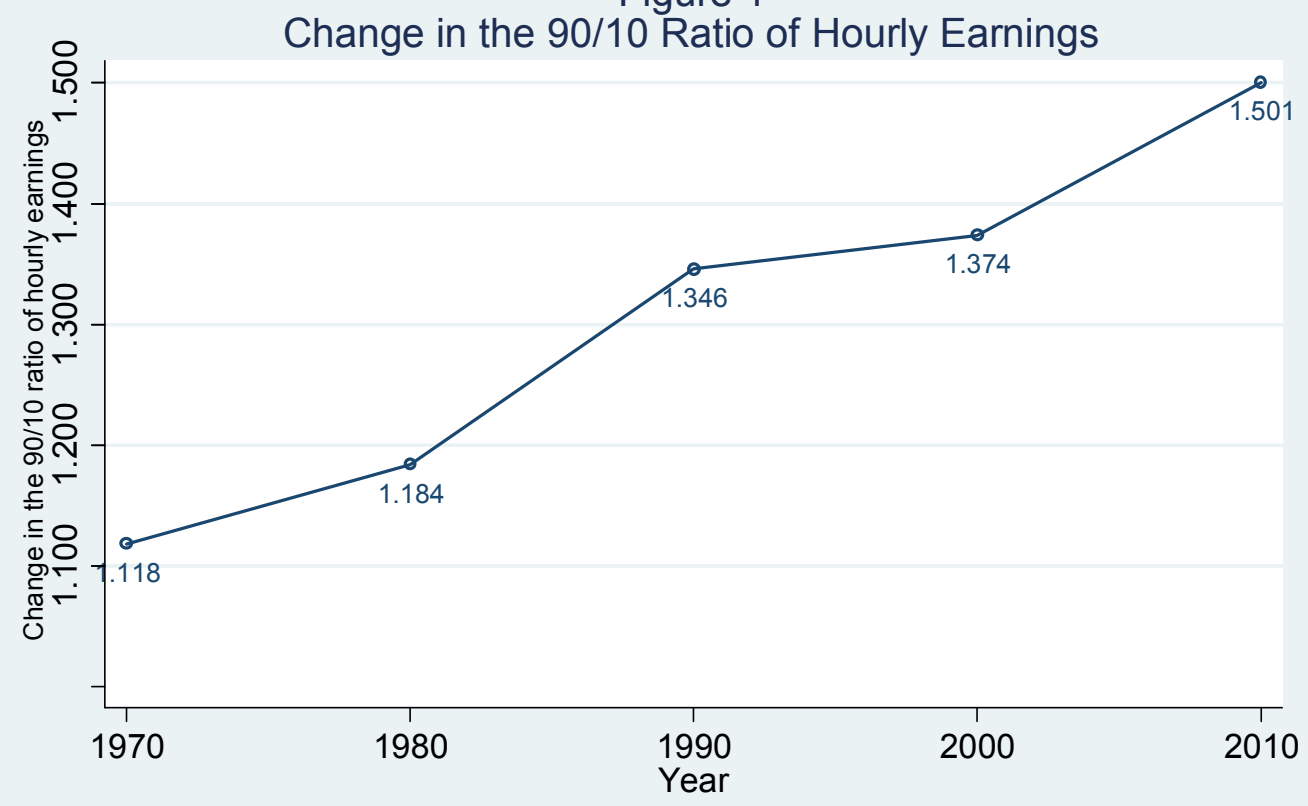

Notes: The sample includes white native men between the ages of 25 and 55 who are full time workers. The sample does not include those in group quarters, self-employed, or in the military.

Figure 2

Change in the $90 / 50$ and 50/10 Ratio of Hourly Earnings

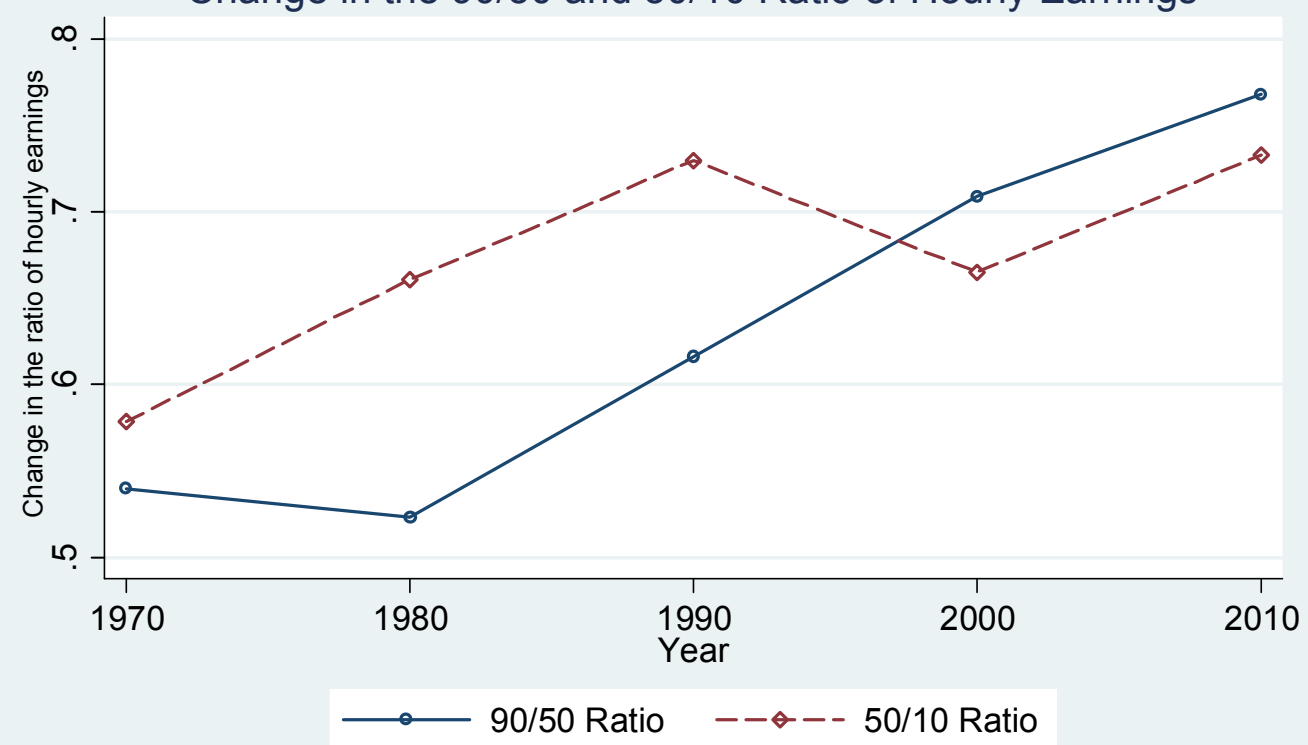

Notes: The sample includes white native men between the ages of 25 and 55 who are full time workers. The sample does not include those in group quarters, self-employed, or in the military. 

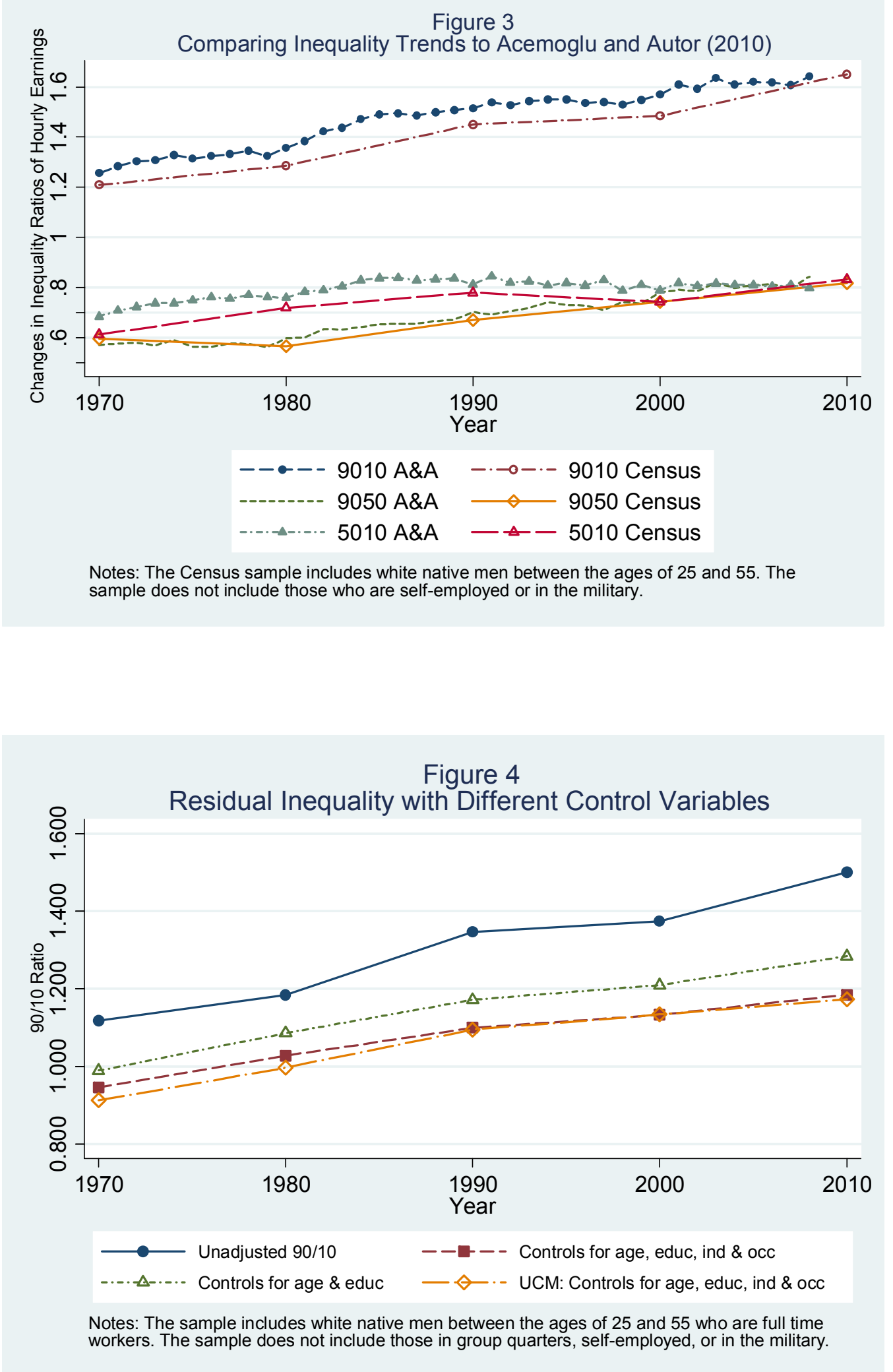
Figure 5

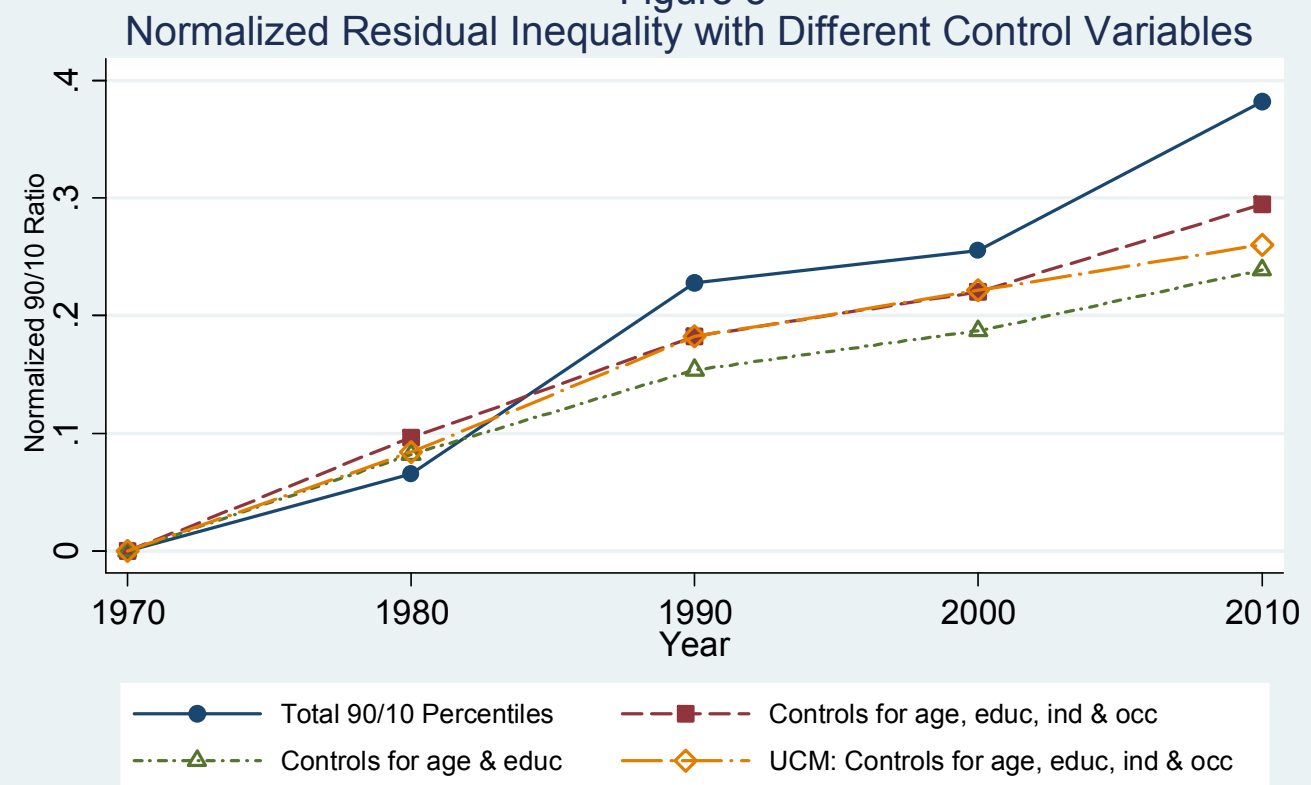

Notes: The sample includes white native men between the ages of 25 and 55 who are full time workers. The sample does not include those in group quarters, self-employed, or in the military.

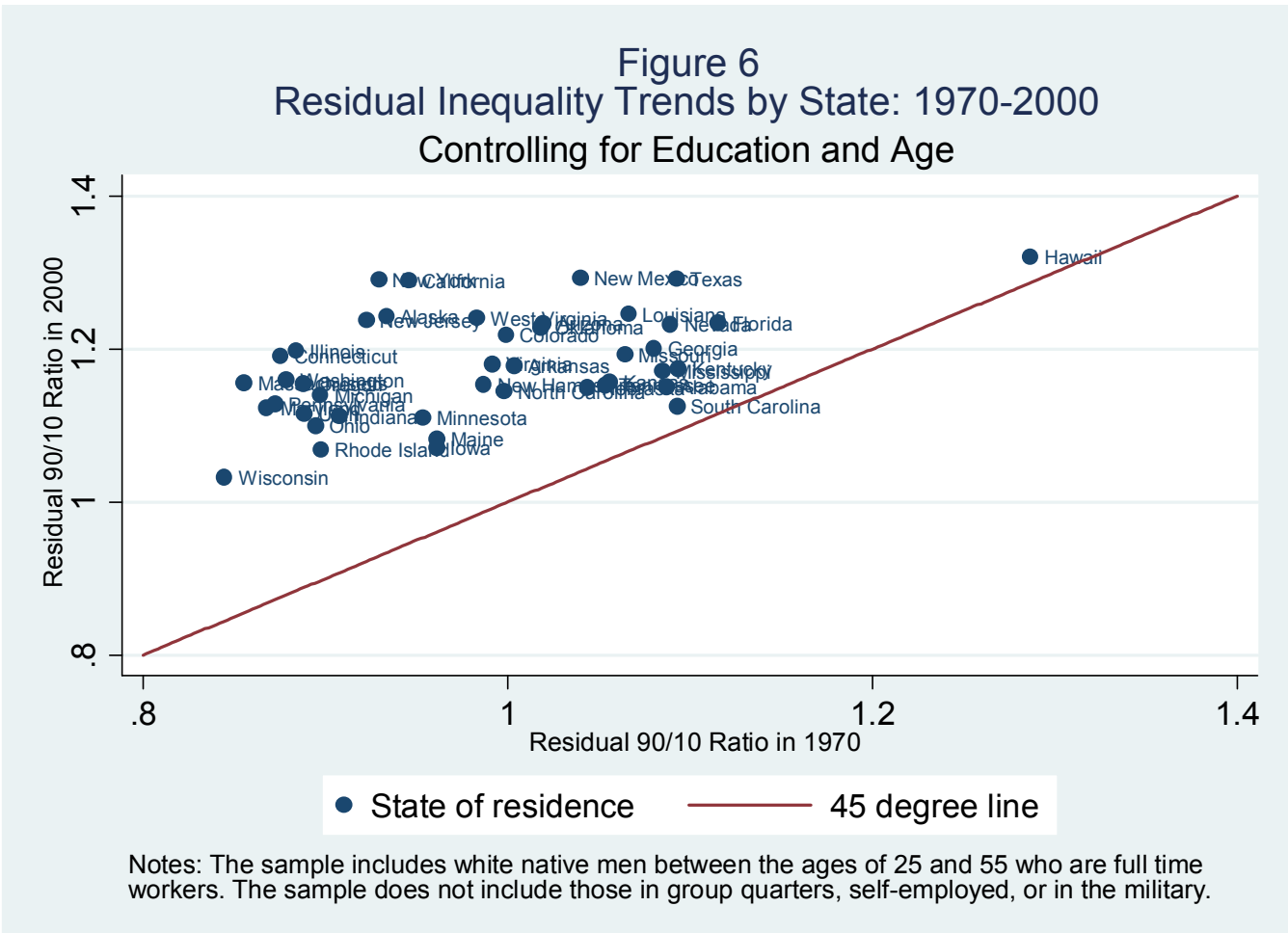


Figure 7

Residual Inequality Trends by State: 1970-2010 Controlling for Education and Age

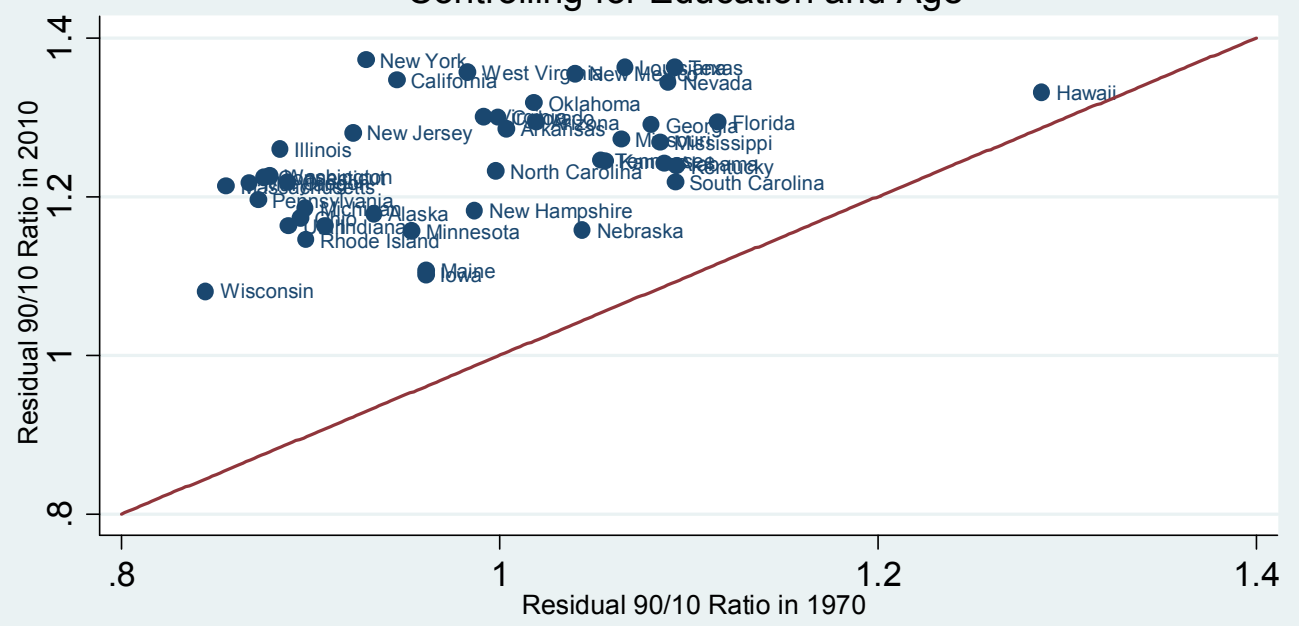

- State of residence

45 degree line

Notes: The sample includes white native men between the ages of 25 and 55 who are full time workers. The sample does not include those in group quarters, self-employed, or in the military.

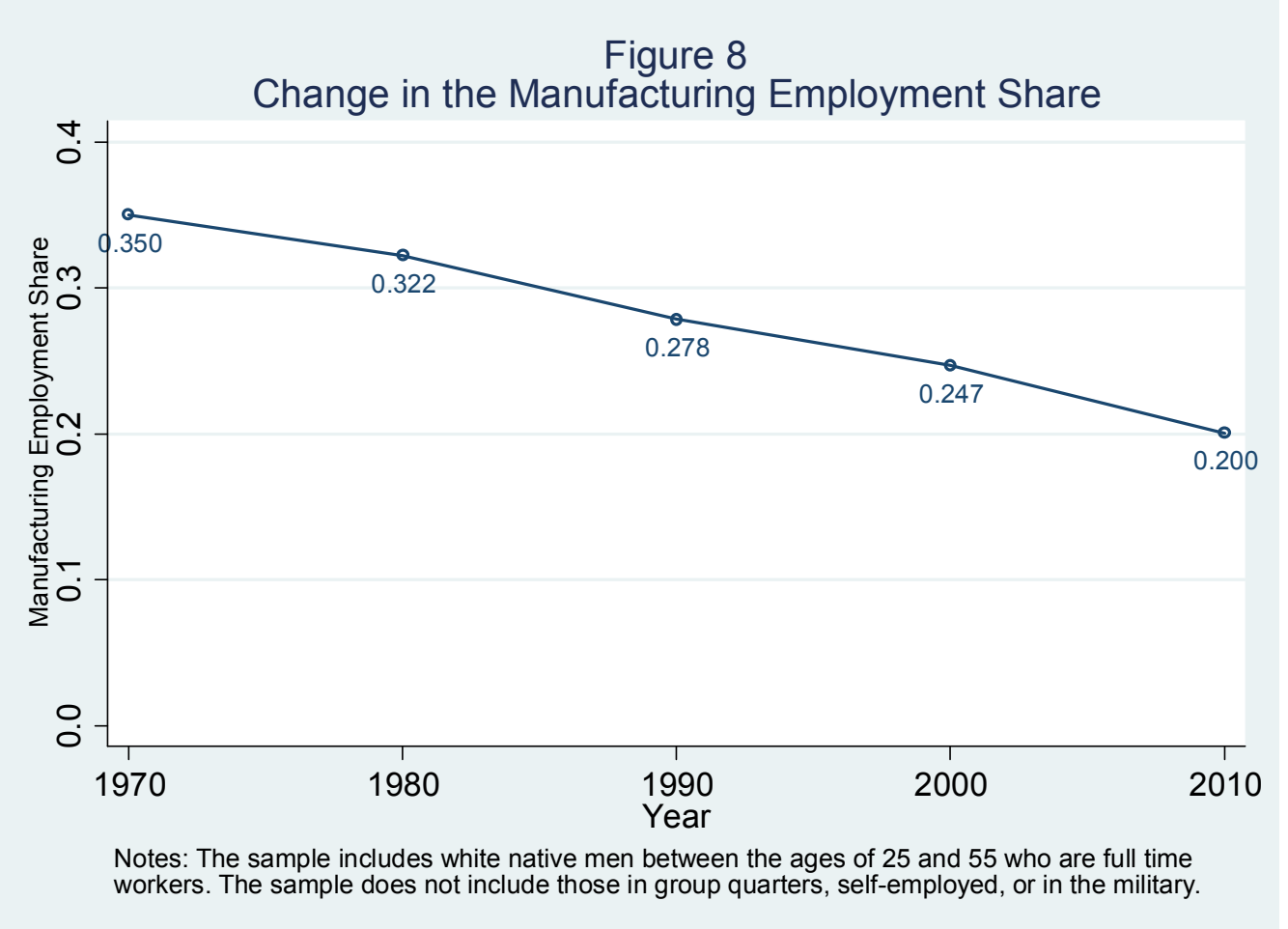


Figure 9: Mean Wage by Industry in 1970

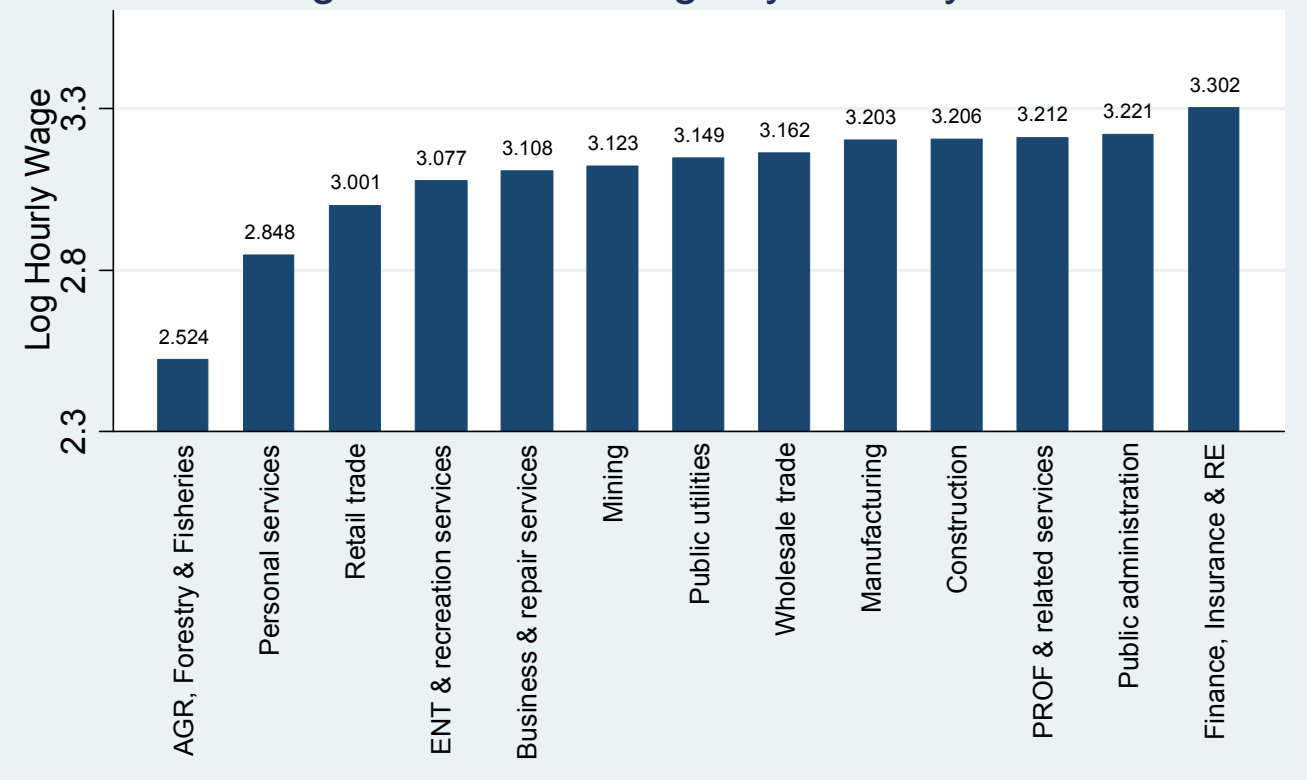

Notes: The sample includes white native men between the ages of 25 and 55 who are full time workers. The sample does not include those in group quarters, self-employed, or in the military.

Figure 10: Change in the Employment Share 1970-2010 Sorted by 1970 Mean Log Wage by Industry

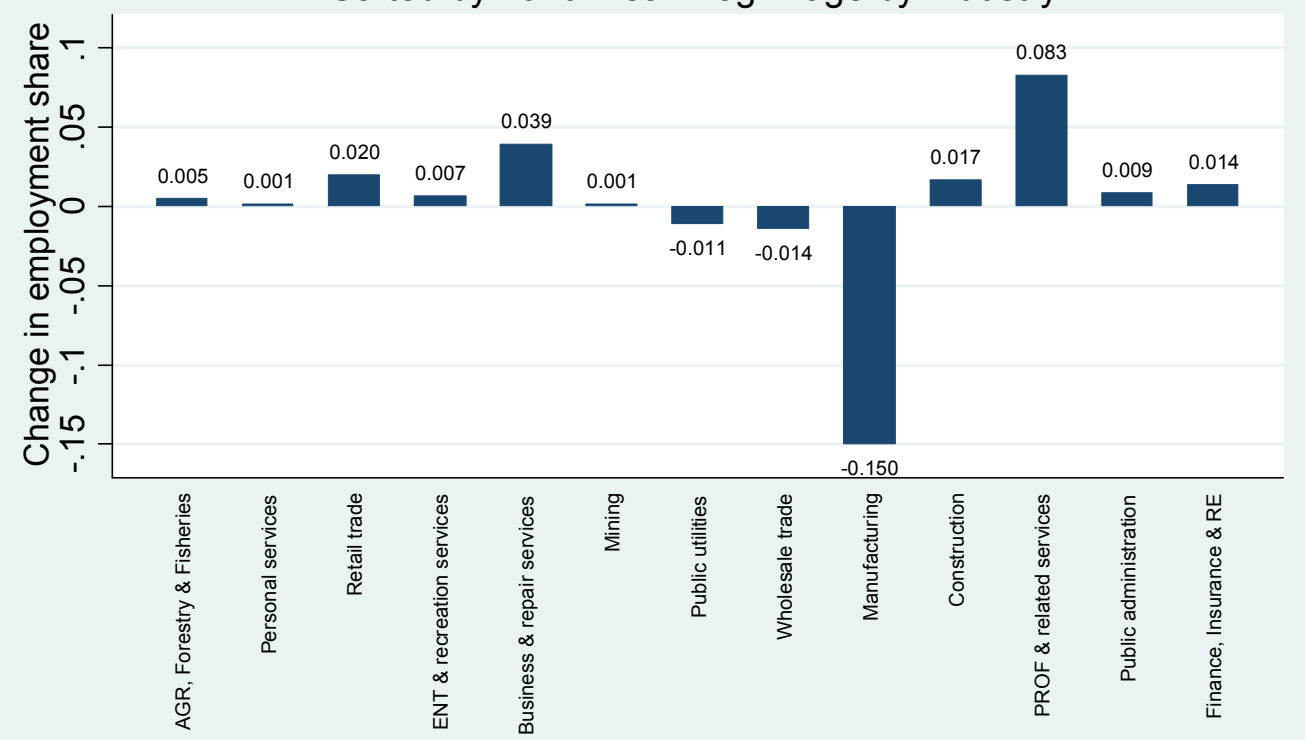

Notes: The sample includes white native men between the ages of 25 and 55 who are full time workers. The sample does not include those in group quarters, self-employed, or in the military. 
Figure 11

Change in Inequality and Manufacturing by State 1980-2010

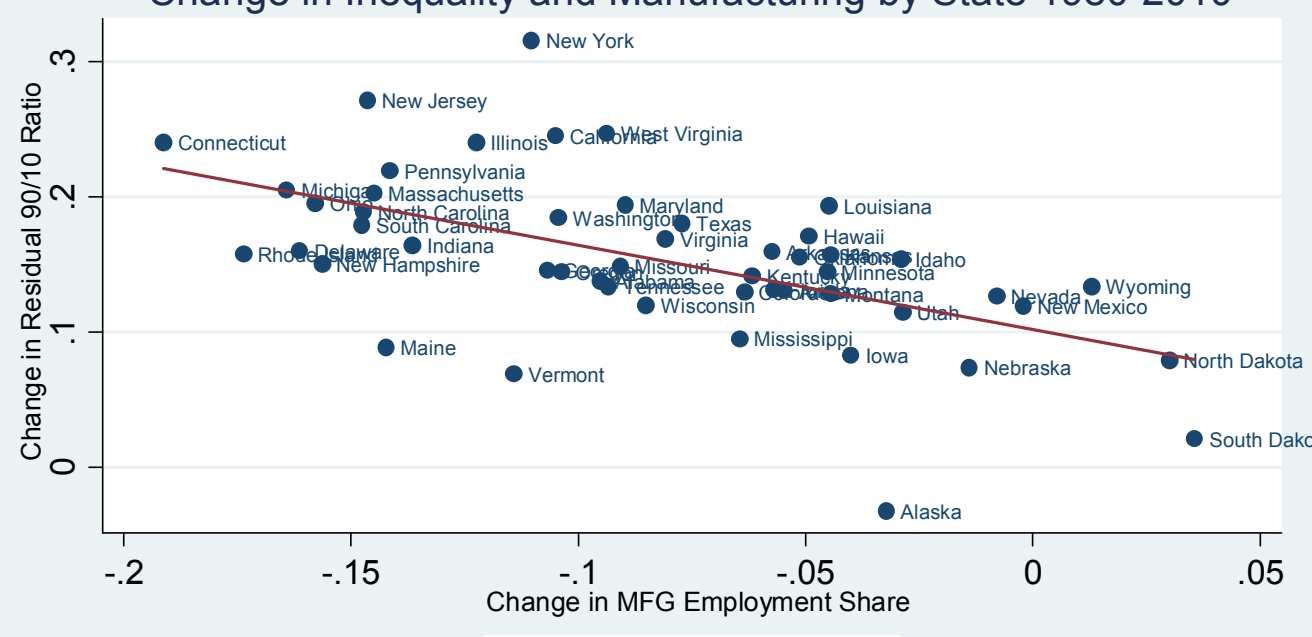

Fitted values

Notes: The inequality sample includes white native men between the ages of 25 and 55 who are full time workers. The sample does not include those in group quarters, self-employed, or in the military. The coefficient of the regression of residual inequality on manufacturing is -.624 and the standard error is .132 .

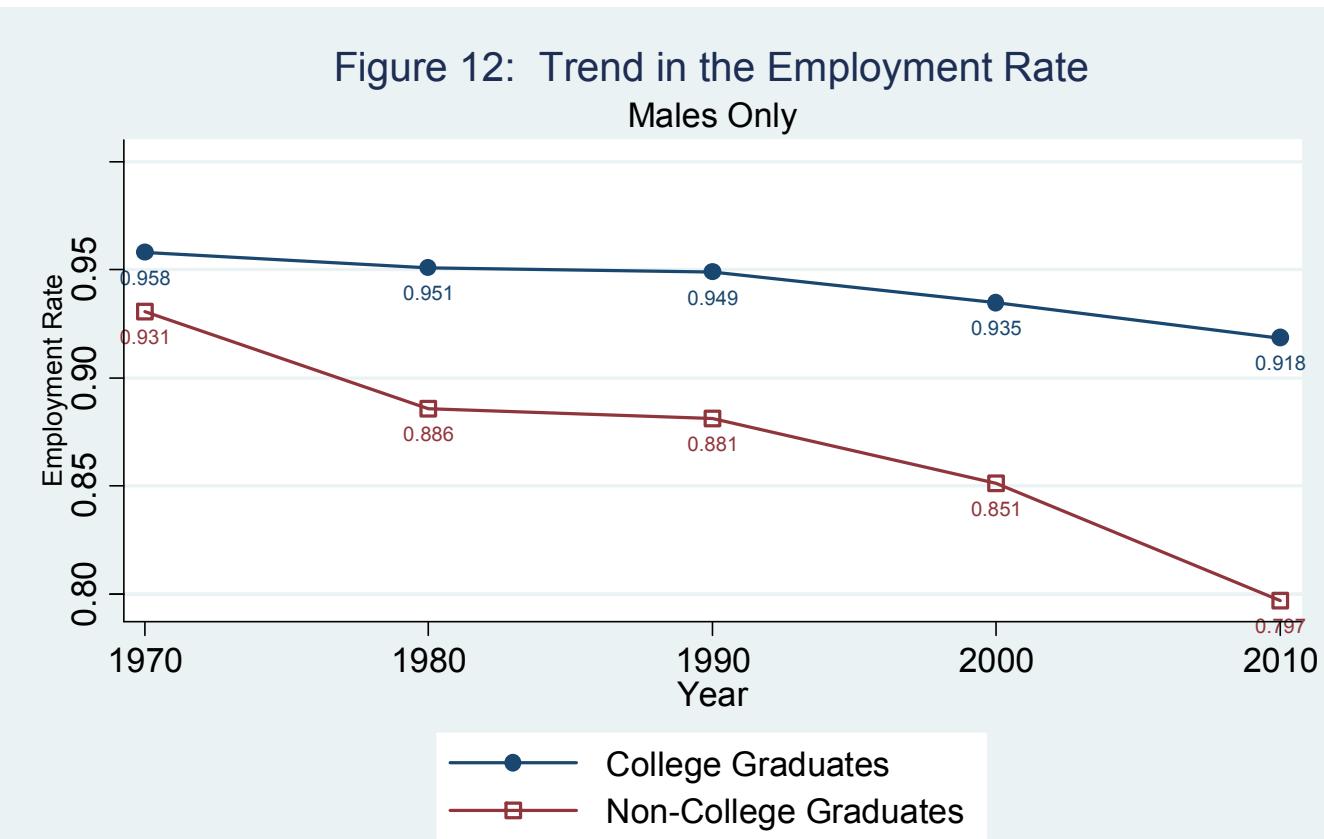

Notes: The sample includes white native men between the ages of 25 and 55 . The sample does not include those in group quarters, or in the military. The employment rate is defined as the percent of the sample defined above that reported being employed. 
Figure 13

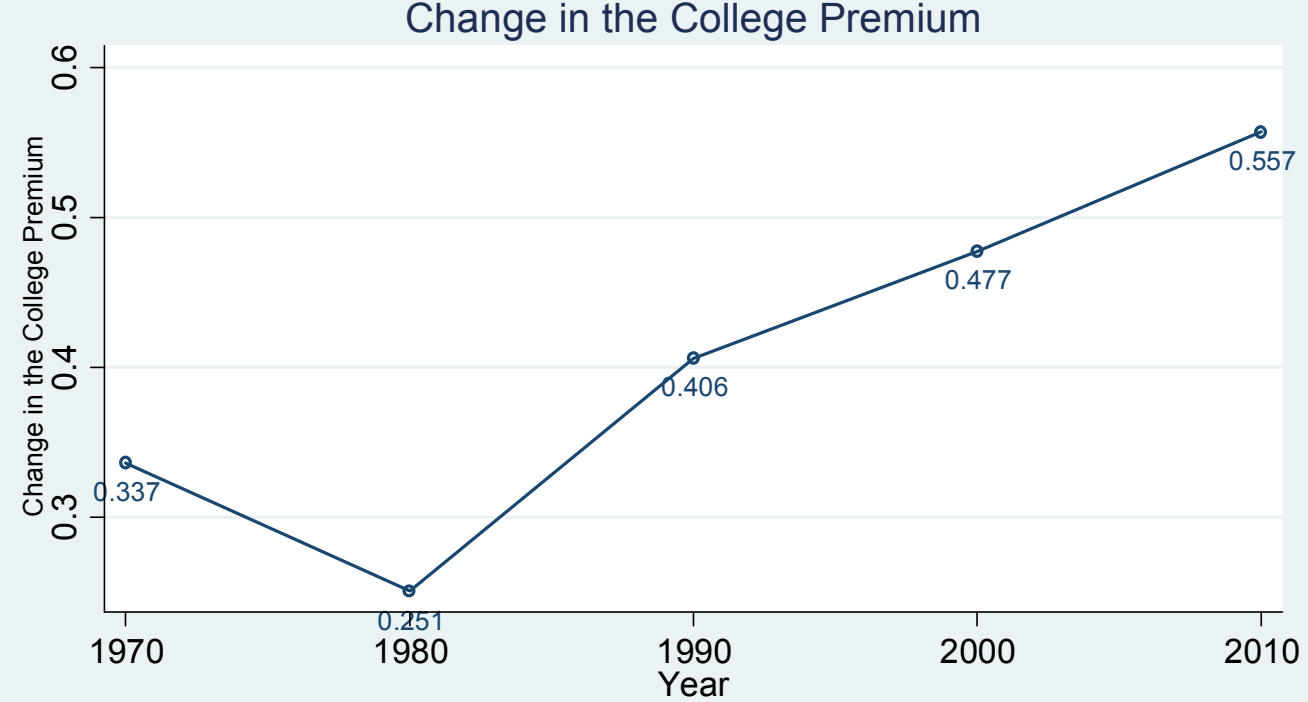

Notes: The sample includes white native men between the ages of 25 and 55 who are full time workers. The sample does not include those in group quarters, self-employed, or in the military. The college premium is defined as the coefficient on the dummy variable for being a college graduate after controlling for state, year and age. The omitted education category is high schoo graduates.

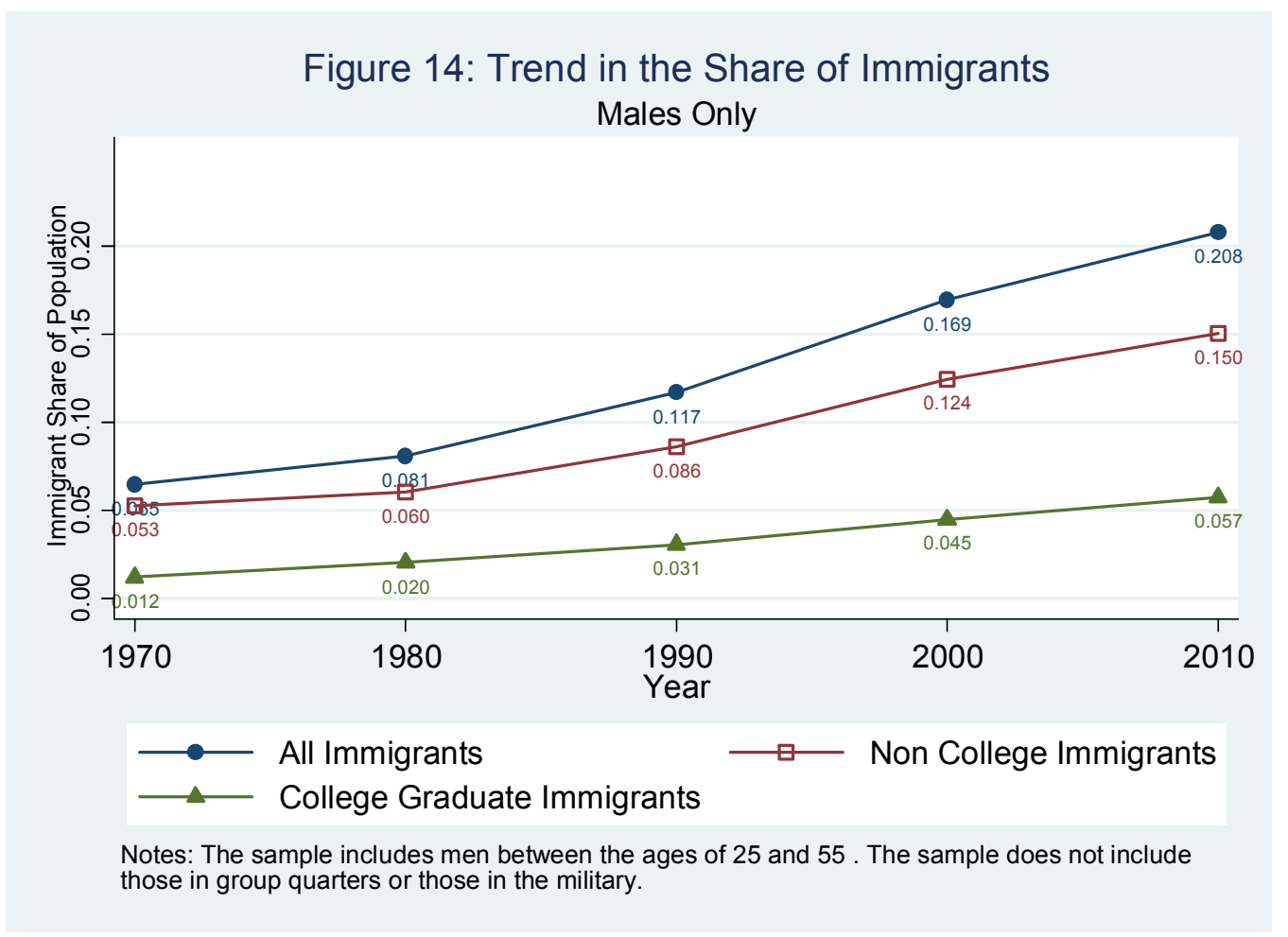




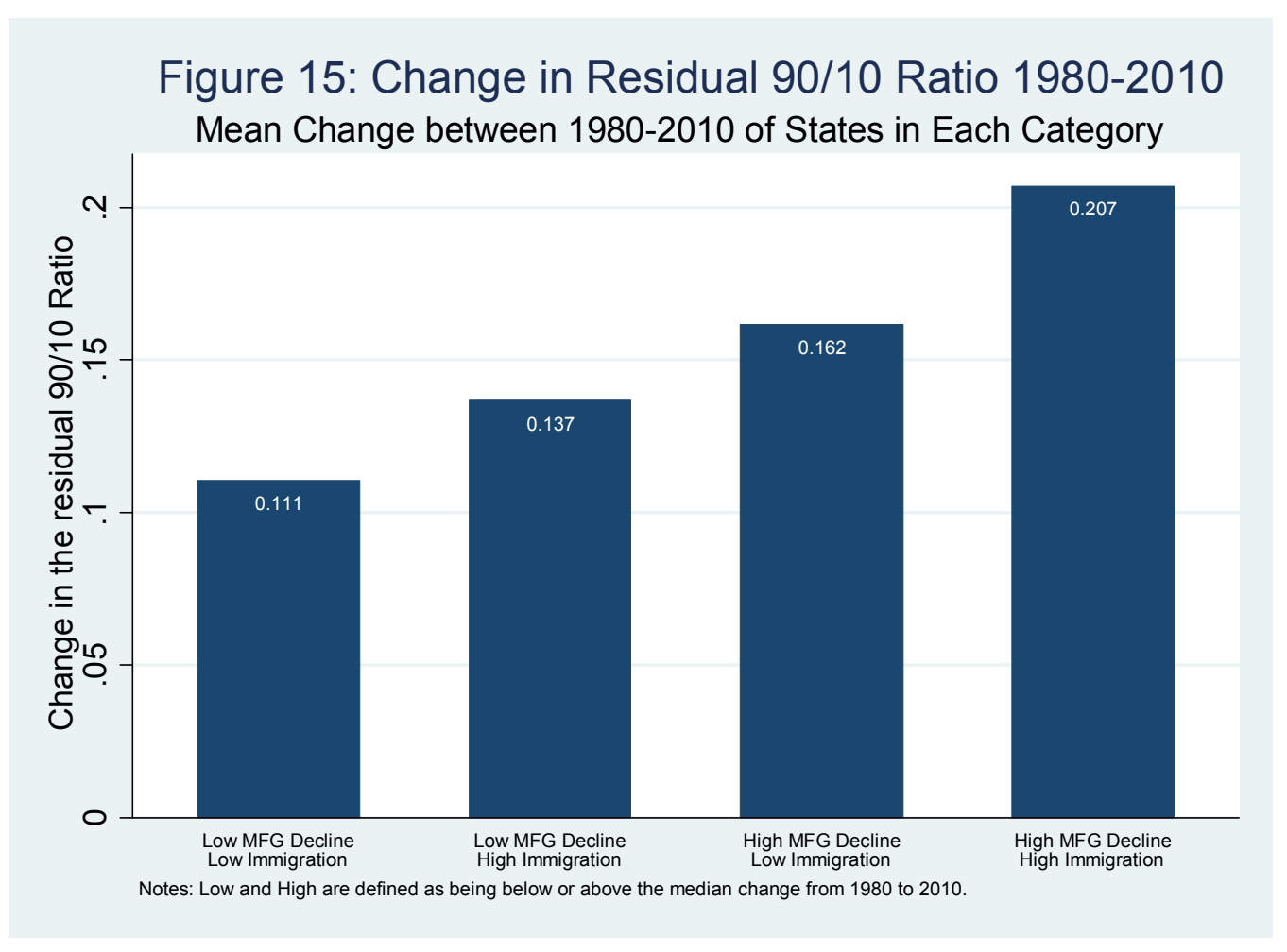

Figure 16: Change in Non-College Employment Rate 1980-2010 Mean Change between 1980-2010 of States in Each Category

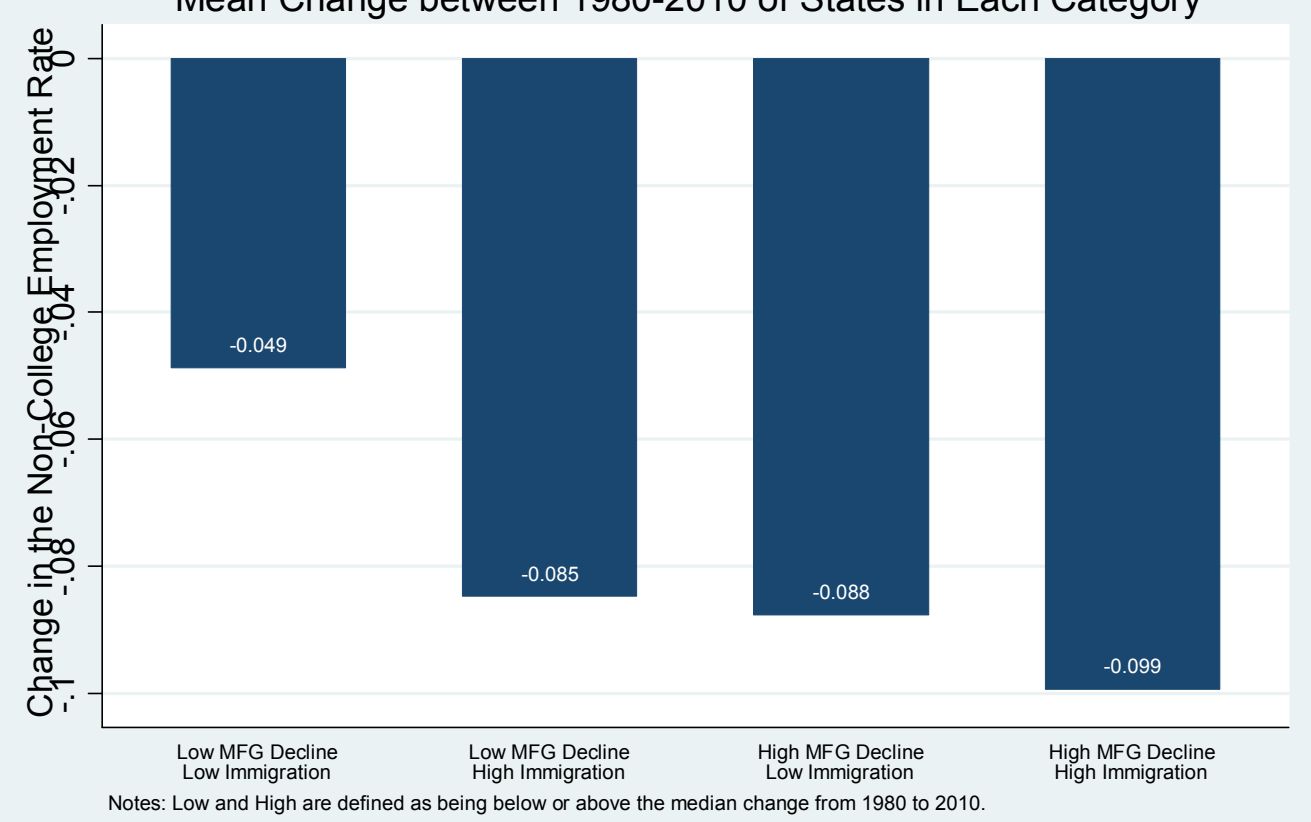






Notes: The mean residual inequality controls for age and education. The sample includes white native men between the ages of 25 and 55 who are full time workers. The sample does not include those in group quarters, self-employed, or in the military.

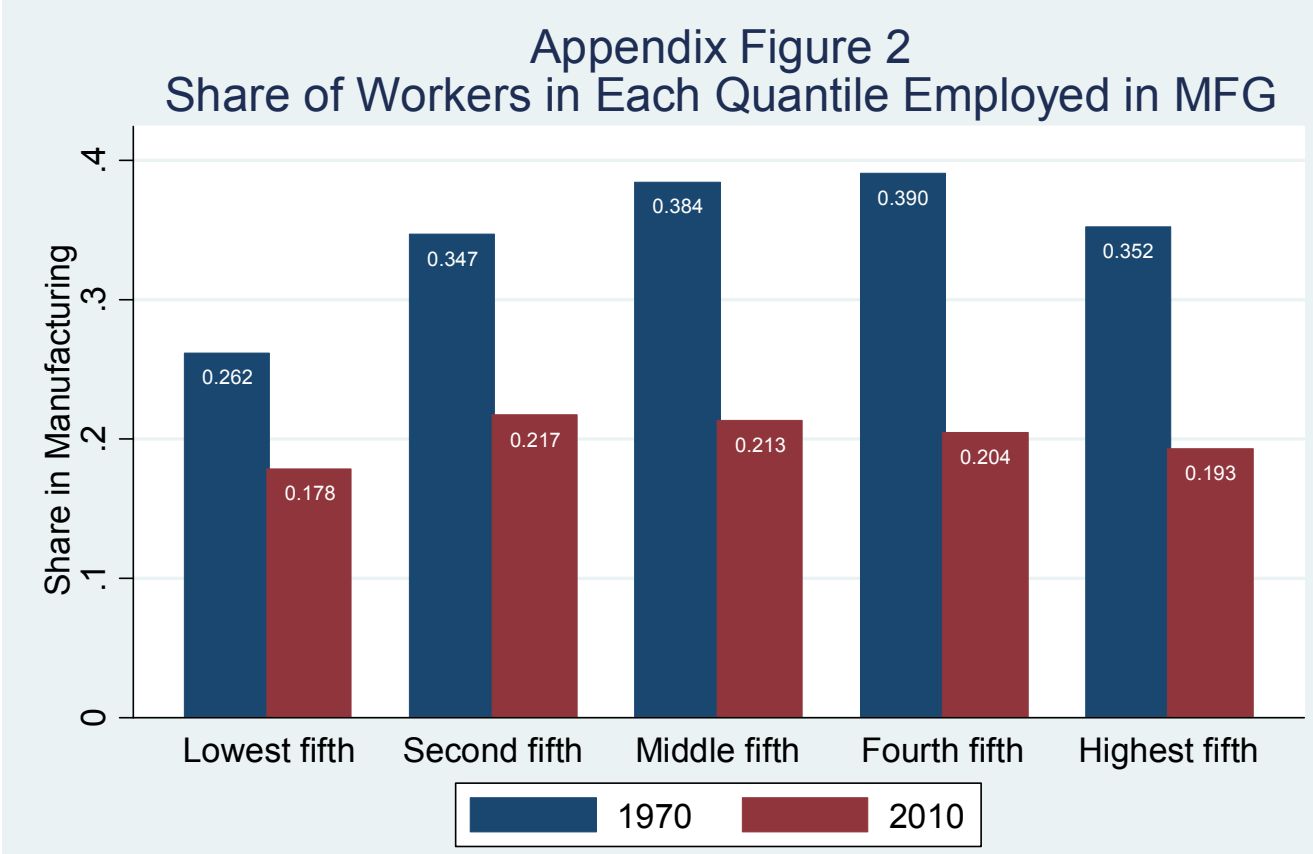

Notes: The sample includes white native men between the ages of 25 and 55 who are full time workers. The sample does not include those in group quarters, self-employed, or in the military. 


\section{Appendix Figure 3 \\ Education Distribution of Workers in 1970}

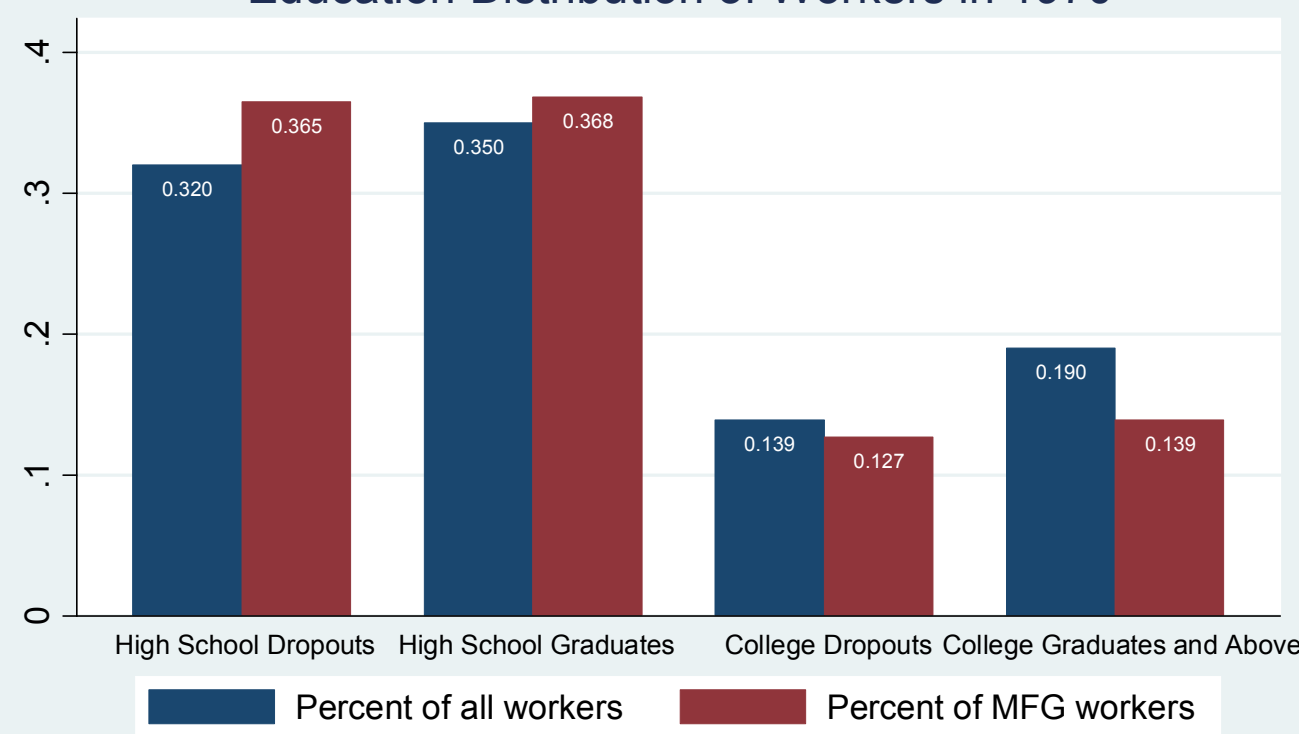

Notes: The sample includes white native men between the ages of 25 and 55 who are full time workers. The sample does not include those in group quarters, self-employed, or in the military.

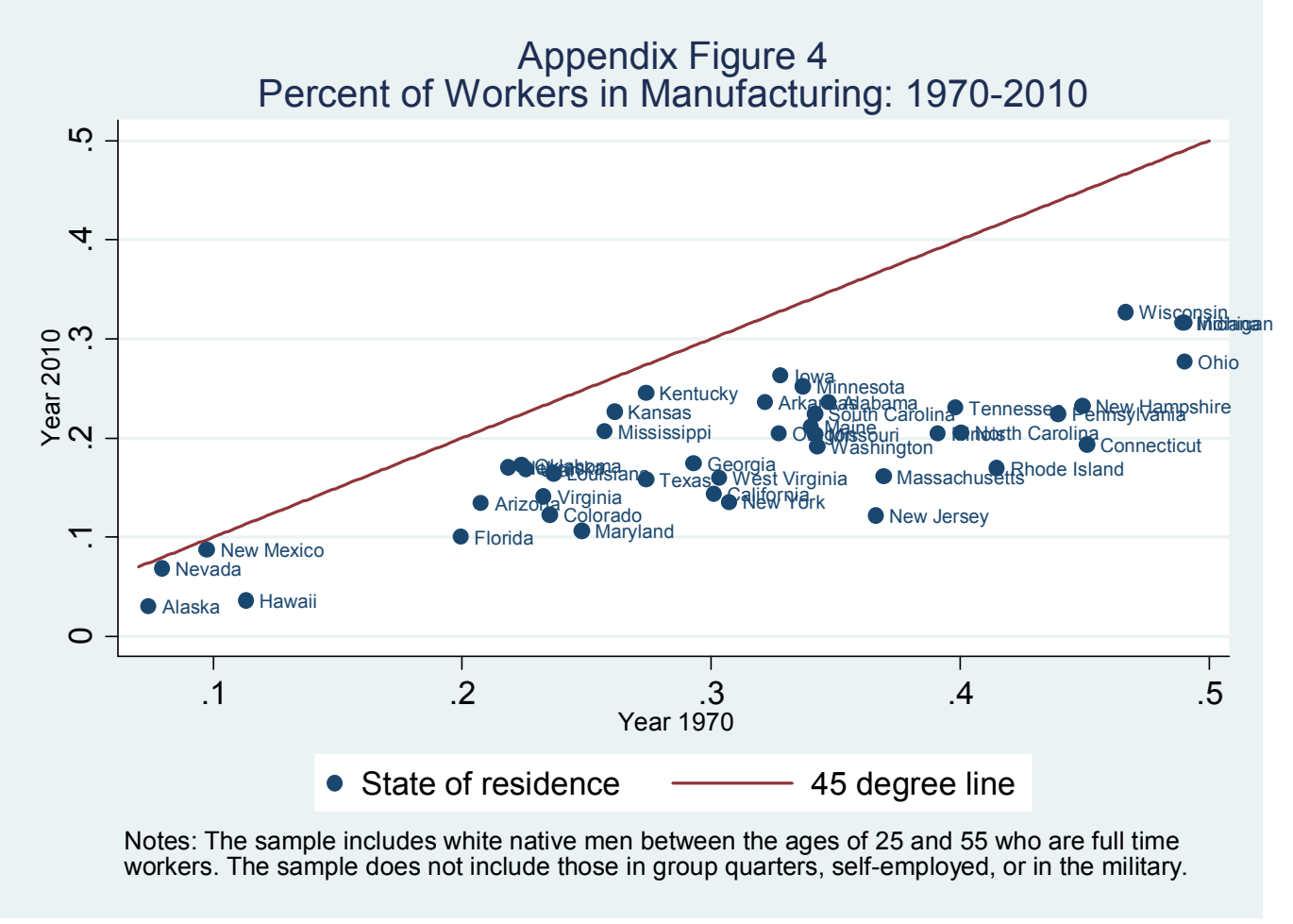



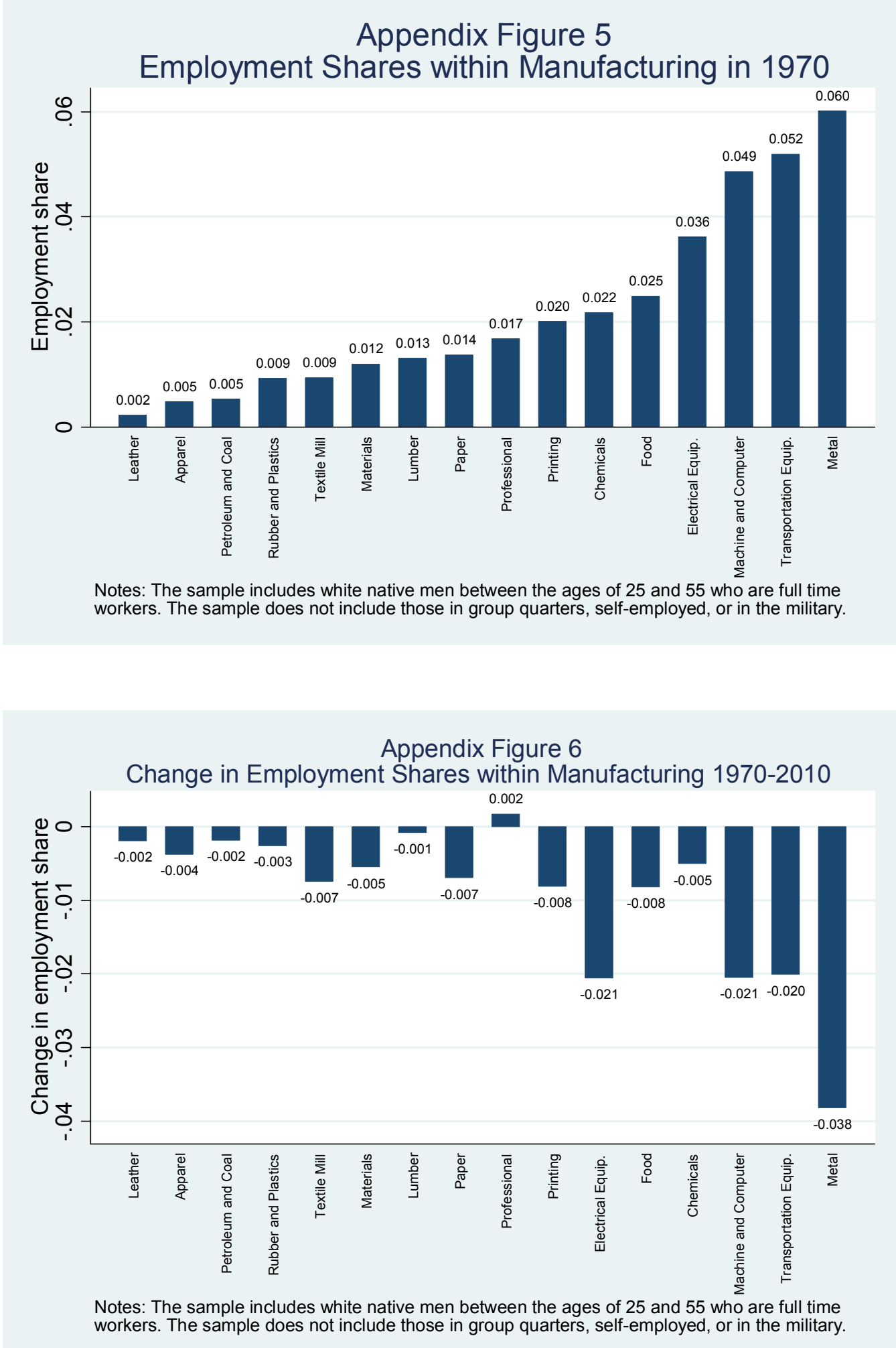


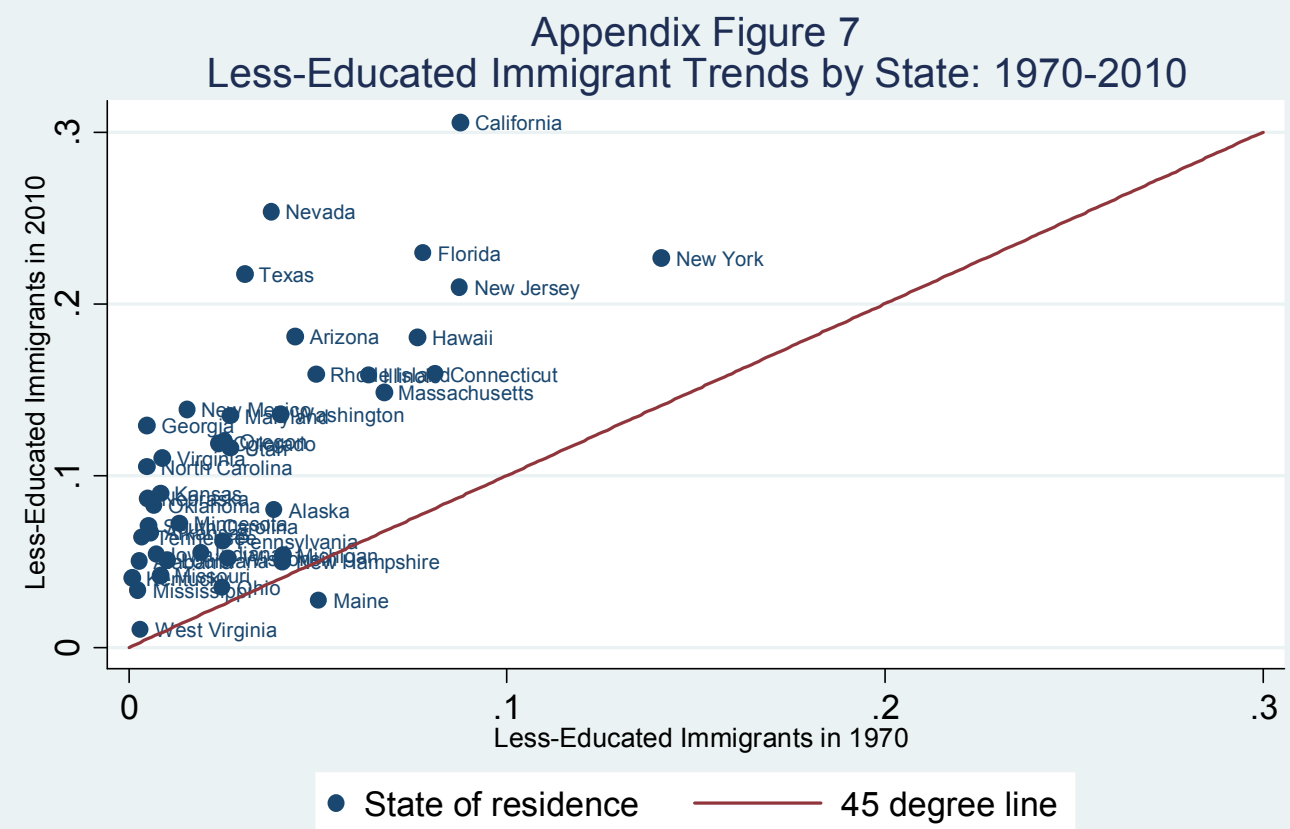

Notes: The sample includes men between the ages of 25 and 55, who are not in group quarters or in the military.

\section{Appendix Figure 8}

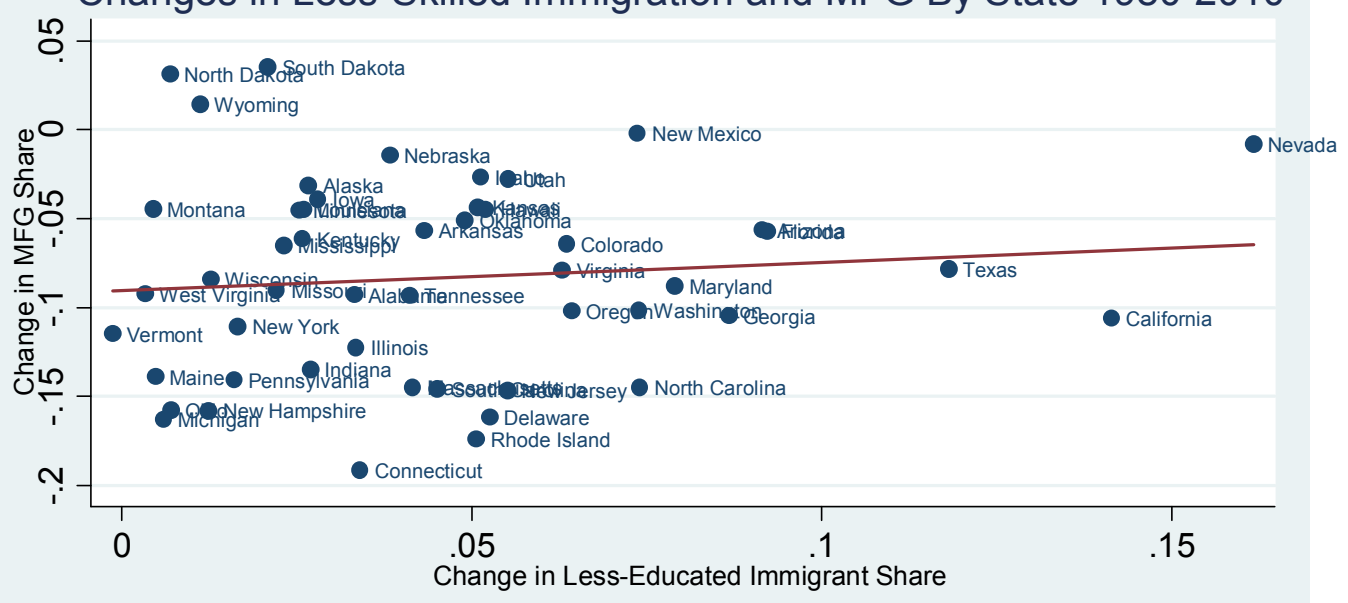

\section{Fitted values}

Notes: The MFG sample includes white native men between the ages of 25 and 55 who are full time workers. This sample does not include those in group quarters, self-employed, or in the military. The immigrant sample includes men between the ages of 25 and 55, who are not in group quarters or in the military. The coefficient of the regression of non-college educated immigrants on manufacturing is .160 and the standard error is .227 . 